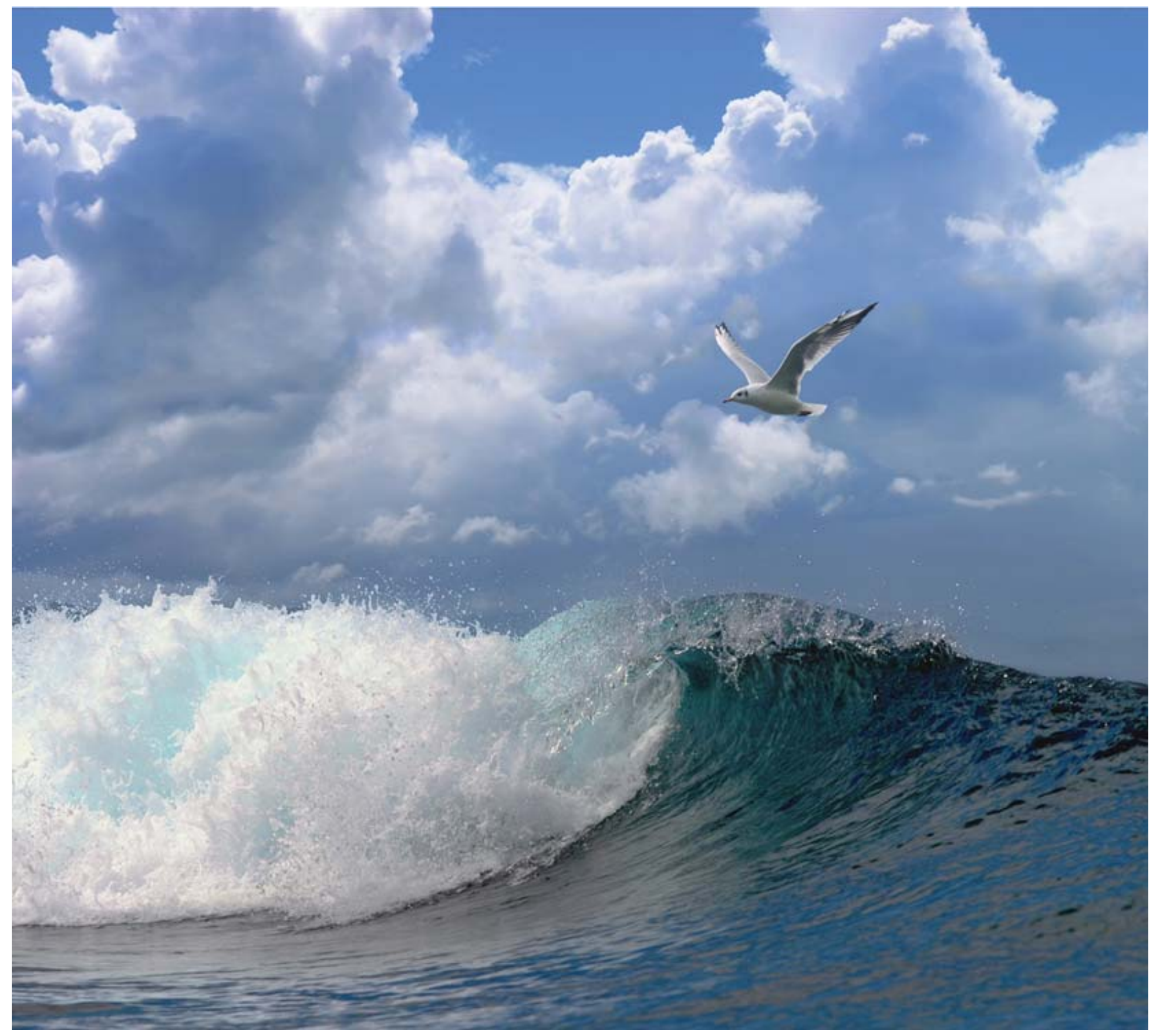

Habitatgeschiktheidsanalyse voor stekelrog (Raja clavata) in Oosterschelde en Voordelta 



\section{Habitatgeschiktheidsanalyse voor stekelrog (Raja clavata) in Oosterschelde en Voordelta}

Auteur(s): $\quad$ R.H. Jongbloed, H.M.J. van Overzee, R. van Hal

Publicatiedatum: 18 augustus 2017

Wageningen Marine Research IJ muiden, augustus 2017

VERTROUWELIJK Nee

Wageningen Marine Research rapport C059/17 
R.H. Jongbloed, H.M.J . van Overzee, R. van Hal , 2017. Habitatgeschiktheidsanalyse voor stekelrog (Raja clavata) in Oosterschelde en Voordelta; . Wageningen Marine Research Wageningen UR (University \& Research centre), Wageningen Marine Research rapport C059/17. 72 blz

Keywords: herintroductie, habitat, verspreiding, abiotische factoren, vis survey, roggen.

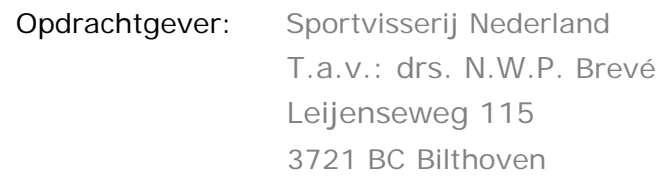

Dit rapport is gratis te downloaden van https://doi.org/10.18174/421686

Wageningen Marine Research verstrekt geen gedrukte exemplaren van rapporten.

Wageningen Marine Research Wageningen UR is ISO 9001:2008 gecertificeerd.

\section{(C) 2017 Wageningen Marine Research Wageningen UR}

Wageningen Marine Research, onderdeel van Stichting Wageningen Research KvK nr. 09098104,

IMARES BTW nr. NL 8113.83.696.B16. Code BIC/SWIFT address: RABONL2U IBAN code: NL 73 RABO 0373599285
De Directie van Wageningen Marine Research is niet aansprakelijk voor gevolgschade, noch voor schade welke voortvloeit uit toepassingen van de resultaten van werkzaamheden of andere gegevens verkregen van Wageningen Marine Research opdrachtgever vrijwaart Wageningen Marine Research van aanspraken van derden in verband met deze toepassing.

Dit rapport is vervaardigd op verzoek van de opdrachtgever hierboven aangegeven en is zijn eigendom. Niets uit dit rapport mag weergegeven en/of gepubliceerd worden, gefotokopieerd of op enige andere manier gebruikt worden zonder schriftelijke toestemming van de opdrachtgever. 


\section{Inhoud}

$\begin{array}{lr}\text { Samenvatting } & \mathbf{5}\end{array}$

$\begin{array}{lr}\text { Summary } & 7\end{array}$

$\begin{array}{llr}1 & \text { Inleiding } & 9\end{array}$

$\begin{array}{lll}1.1 & \text { Aanleiding en kennisvragen } & 9\end{array}$

$\begin{array}{ll}1.2 & \text { Afbakening }\end{array}$

$\begin{array}{ll}1.3 \text { Aanpak } & 10\end{array}$

$\begin{array}{lll}1.4 & \text { Studiegebied } & 10\end{array}$

$\begin{array}{lll}1.4 .1 & \text { Voordelta } & 11\end{array}$

$\begin{array}{lll}1.4 .2 & \text { Oosterschelde } & 12\end{array}$

$\begin{array}{lll}1.5 & \text { Opbouw rapport } & 12\end{array}$

$2 \quad$ Biologie en verspreiding van de stekelrog $r$

$\begin{array}{lll}2.1 & \text { Ecologie van de stekelrog } & 14\end{array}$

$\begin{array}{lll}2.2 & \text { Historische verspreiding van de stekelrog in de Noordzee } & 15\end{array}$

2.3 Recente verspreiding van de stekelrog op de internationale Noordzee 17

$\begin{array}{lll}2.4 & \text { Migratie van de stekelrog } & 17\end{array}$

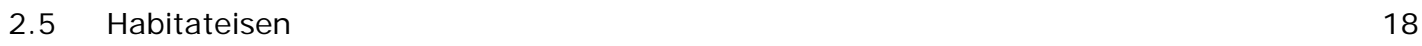

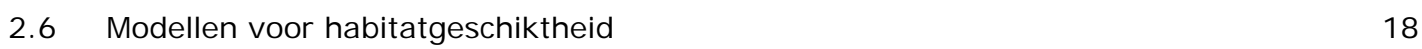

3 Vangsten van stekelroggen in Noordzee, Oosterschelde en Voordelta 20

$\begin{array}{lll}3.1 & \text { Nederlandse aanlandingsgegevens (VISSTAT) } & 20\end{array}$

$\begin{array}{lll}3.1 .1 & \text { Methode } & 20\end{array}$

$\begin{array}{lll}3.1 .2 & \text { Selectie van gegevens } & 20\end{array}$

$\begin{array}{lll}3.1 .3 & \text { Resultaten } & 21\end{array}$

$\begin{array}{lll}3.2 & \text { Demersale surveys } & 27\end{array}$

$\begin{array}{lll}3.2 .1 & \text { Voordelta } & 27\end{array}$

$\begin{array}{lll}3.2 .2 & \text { Oosterschelde } & 28\end{array}$

$4 \quad$ Habitateisen van de stekelrog $\quad 29$

$\begin{array}{lll}4.1 & \text { Abiotische factoren } & 29\end{array}$

$\begin{array}{lll}4.2 & \text { Biotische factoren } & 33\end{array}$

$\begin{array}{lll}4.3 & \text { Conclusies } & 34\end{array}$

$5 \quad$ Habitatgeschiktheid Oosterschelde en Voordelta voor de stekelrog 35

$\begin{array}{lll}5.1 & \text { Abiotische factoren } & 35\end{array}$

$\begin{array}{lll}5.2 & \text { Biotische factoren } & 40\end{array}$

6 Discussie $\quad 41$

6.1 Data beschikbaarheid stekelrog 41

6.2 Abiotische factoren en habitatgeschiktheid $\quad 41$

6.3 Beperkte biologische kennis $\quad 42$

6.4 Migratie en bereikbaarheid 42

$\begin{array}{lll}6.5 & \text { Expert judgement } & 43\end{array}$

$7 \quad$ Conclusies en aanbevelingen $\quad 48$

$\begin{array}{llr}7.1 & \text { Conclusies } & 48\end{array}$ 
Bijlage 1 I UCN/ SSC richtlijnen voor herintroductie van soorten

Bijlage 2 Kenmerken van surveys

Bijlage 3 I nspanning demersal surveys Voordelta

Bijlage 4 Kaart garnalendichtheid Voordelta en Oosterschelde 60

Bijlage $5 \quad$ Kaart diepte Voordelta

Bijlage $6 \quad$ Kaart diepte Oosterschelde

Bijlage 7 Kaart sediment Voordelta

Bijlage 8 Kaart sediment en droogvalduur Oosterschelde 64

Bijlage $9 \quad$ Kaart bodemschuifspanning Voordelta $\quad 65$

$\begin{array}{lll}\text { Bijlage } 10 & \text { Kaart stroomsnelheid Oosterschelde } & 66\end{array}$

$\begin{array}{lll}\text { Bijlage } 11 & \text { Kaart zoutgehalte Voordelta } & 67\end{array}$

$\begin{array}{lll}\text { Bijlage } 12 & \text { Grafiek zoutgehalte Oosterschelde } & 68\end{array}$

$\begin{array}{lll}\text { Bijlage } 13 \quad \text { Grafiek watertemperatuur Voordelta } & 69\end{array}$

$\begin{array}{lll}\text { Bijlage } 14 & \text { Grafiek watertemperatuur Oosterschelde } & \mathbf{7 0}\end{array}$

$\begin{array}{lll}\text { Bijlage } 15 \quad \text { Kaart ecotopen Oosterschelde } & 71\end{array}$ 


\section{Samenvatting}

In dit rapport wordt een habitatgeschiktheidsanalyse van de Oosterschelde en de Voordelta voor de stekelrog (Raja clavata) uitgevoerd. Deze habitatgeschiktheidsanalyse is een eerste beoordeling en geen uitgebreide habitatmodellering. De opdrachtgever is van plan gekweekte stekelroggen uit te zetten in de Oosterschelde indien er goede kansen zijn dat dit bijdraagt aan de toename van het aantal stekelroggen dat gebruik gaat maken van de Oosterschelde en de Voordelta. De stekelrog komt in de laatste decennia zeer sporadisch voor in de Oosterschelde en Voordelta, terwijl de soort daar in het begin van de twintigste eeuw veelvuldig werd aangetroffen. In de (internationale) Noordzee is het verspreidingsgebied en de abundantie van de stekelrog gedurende de laatste eeuw afgenomen, met een resterende concentratie in de zuidwestelijke Noordzee en in het Kanaal. In de meest recente jaren is de abundantie stabiel tot toenemend. In een habitatgeschiktheidsanalyse wordt nagegaan welke eisen de stekelrog stelt aan zijn leefomgeving en of daaraan anno 2017 zou kunnen worden voldaan in de Oosterschelde en de Voordelta. Hierbij worden abiotische en biotische omgevingsfactoren betrokken. De eventuele effecten van menselijke activiteiten, zoals visserij en zandsuppleties op stekelroggen, worden in dit rapport buiten beschouwing gelaten.

Uit de gegevens over vangsten van stekelroggen in Nederlandse aanlandingen en surveys in Oosterschelde en Voordelta blijkt dat deze soort sinds 1970 sporadisch wordt aangetroffen. Het beperkte aantal waarnemingen maakt het onmogelijk om een habitatgeschiktheidsanalyse uit te voeren m.b.v. correlaties tussen presentie van stekelrog en omgevingsfactoren. Wel kan er gebruik worden gemaakt van dergelijke correlaties die zijn vastgesteld in andere gebieden.

Belangrijke abiotische randvoorwaarden voor de ontwikkeling van het aantal stekelroggen dat gebruik maakt van deze gebieden zijn diepte, bodemschuifspanning, temperatuur, saliniteit en sediment type die passen bij de habitateisen van de stekelrog. Biotische factoren zoals voedselaanbod (m.n. kreeftachtigen) zijn ook belangrijk maar zijn in de betreffende gebieden waarschijnlijk niet beperkend. Competitie, predatie, parasieten en ziekten zijn eveneens van belang maar daarvan is niet aan te geven in hoeverre die beperkingen opleveren voor de ontwikkeling van stekelroggen en in hoeverre de gebieden hierin van elkaar verschillen ten opzichte van andere gebieden op de Noordzee.

Een schatting van de potentiele geschiktheid van Oosterschelde en Voordelta voor de stekelrog is uitgevoerd voor bovengenoemde abiotische en biotische omgevingsfactoren. Hierbij is onderscheid gemaakt tussen enerzijds juveniele stekelrog ( 0 en 1 jarig) en anderzijds subadulte en adulte stekelrog $(2+$ jarig $)$, omdat habitateisen verschillen voor deze groepen. De beide gebieden Oosterschelde en Voordelta verschillen in relevante omgevingsfactoren, welke daarnaast ruimtelijk en temporeel variëren. Met name de lage watertemperatuur is in de wintermaanden voor beide groepen stekelrog sterk beperkend in de Oosterschelde en Voordelta. Lage saliniteit en grote bodemdynamiek zijn beperkend in een klein deel van de Voordelta.

$\mathrm{Er}$ is verder gekeken naar gegevens over het voorkomen van de stekelrog in het verleden, als een kwalitatieve ijking van de geschiktheid van gebieden. De voorlopige conclusie is dat uit de geschiktheidsanalyse blijkt dat de gebieden in potentie geschikt kunnen zijn als habitat voor de stekelrog. Het is mogelijk dat er andere maar nog onbekende factoren zijn die mede de kwaliteit van het habitat voor stekelroggen bepalen. Dit geldt bijvoorbeeld m.b.t. structuren op de bodem nodig voor het afzetten van eikapsels. Daarnaast is te veronderstellen dat er biotische factoren zijn die hierbij een sturende rol spelen, maar daarover is weinig bekend uit de wetenschappelijke literatuur. Het voedselaanbod (kreeftachtigen) in Oosterschelde en Voordelta zal voor stekelroggen waarschijnlijk voldoende zijn. Over de concurrentie met andere vissoorten om voedsel is echter niets bekend. Andere biotische factoren zijn predatie op eikapsels en juveniele stekelroggen en parasieten en ziekten. 
Uit de analyse op basis van de gegevens uit de literatuur en de mening van de betrokken experts blijkt dat het nog niet mogelijk is een kwantitatieve schatting te geven voor het huidige en toekomstige aantal (dichtheid) stekelroggen per oppervlakte-eenheid in Oosterschelde en Voordelta.

Er worden een aantal aanbevelingen gedaan om kennislacunes in te vullen waarna op kwantitatieve wijze, met rekenregels en GIS een voorspelling kan worden gedaan van de (relatieve) habitatgeschiktheid binnen de Oosterschelde en de Voordelta.

Gezien de aannames en onzekerheden is empirische toetsing van de conclusies via monitoring van uitgezette stekelroggen met merk-terugvangst en met elektronische data storage tags een noodzakelijke stap in de verdere ontwikkeling van kennis over de stekelrog in de Oosterschelde en de Voordelta. Deze aanpak kan ook dienen als voorbeeld voor habitatgeschiktheidsanalyse voor andere soorten roggen en haaien in dit gebied. 


\section{Summary}

In this report a habitat suitability analysis of the Oosterschelde and the Voordelta for the thornback ray (Raja clavata) is carried out. This habitat suitability analysis is a first assessment and not an extensive habitat modelling. The commissioners intend to release cultivated thornback rays in the Oosterschelde in case there is a good chance that this contributes to an increase of the thornback ray numbers inhabiting the Oosterschelde and the Voordelta. In the last decade's thornback rays are sporadically found in de Oosterschelde en Voordelta, whereas in the start of the twentieth century the species was frequently encountered. In the (international) North Sea the thornback ray distribution area and abundance was reduced during the last century with a remaining concentration in the southwest North Sea and in the eastern English Channel. In the most recent years the abundance is stable to increasing. In this habitat suitability analysis the habitat requirements of the thornback ray concerning abiotic and biotic factors are investigated. It is studied whether the Oosterschelde and Voordelta fulfil these requirements anno 2017. Possible effects of human activities, like fishery and foreshore replenishment, on thornback rays are left out of consideration.

The thornback ray catch data in Dutch landings and surveys in Oosterschelde and Voordelta reveal that this species is sporadically found since 1970. The limited number of observations impedes to conduct a habitat suitability analysis based on correlations between presence of thornback ray and environmental factors. However it is possible to apply the correlations determined for thornback rays in other areas.

I mportant abiotic environmental conditions determining the presence and density of thornback ray are depth, bed shear stress, temperature, salinity and sediment type. Biotic factors like food-supply (mainly crustaceans) are important too, but probably not limiting in the studied areas. Competition, predation, parasites and diseases are also important. However the influence on the presence and abundance of thornback rays cannot be estimated. It is also unknown in what way the biotic factors differ among areas within the North Sea.

An assessment of the potential habitat suitability of Oosterschelde and Voordelta for the thornback ray is carried out based on the abovementioned set of abiotic and biotic environmental factors. A distinction is made between juvenile thornback ray (0-1 group) and sub-adult and adult thornback ray $(2+$ group) because habitat requirements differ among these groups. Oosterschelde and Voordelta differ in relevant environmental factors, which also vary spatially and temporally. In the winter months the low water temperature is limiting both thornback ray groups in the Oosterschelde and the Voordelta. Low salinity and high bed shear stress are limiting factors in a small part of the Voordelta.

Information on the historic spatial distribution of the thornback ray in North Sea is used for a qualitative reference for the suitability of area. The preliminary conclusion from the suitability analysis is that Oosterschelde and Voordelta are potentially suitable as habitat for the thornback ray. It is possible that there are other unknown factors also determining the habitat quality for thornback ray. This applies to e.g. structures on the seafloor necessary for disposal or attachment of egg cases. Moreover biotic factors may be involved. The food-supply (crustaceans) in Oosterschelde and Voordelta for thornback ray is probably sufficient. Information on the occurrence of food competition with other fish species is lacking. Other biotic factors are predation on egg cases and juvenile thornback rays, parasites and diseases.

The analysis which is based on data from literature and expert judgement reveals that it is not yet possible to carry out a quantitative estimation of current and future thornback ray numbers per surface unit (density) in Oosterschelde and Voordelta. 
Recommendations are presented to fill in knowledge gaps. This will generate the information enabling to quantitatively predict the (relative) habitat suitability of the Oosterschelde and the Voordelta, using calculation rules and GIS.

Due to the assumptions and encountered uncertainties, empirical testing of the conclusions via monitoring of released thornback rays with tagging-recapture and with electronic data storage tags is a necessary step in the development of knowledge about the thornback ray in the Oosterschelde and the Voordelta. This approach can serve as an example for habitat suitability analysis for other species of rays and sharks in this area. 


\section{$1 \quad$ Inleiding}

\subsection{Aanleiding en kennisvragen}

Sportvisserij Nederland (SVNL), Wereld Natuur Fonds (WNF), Blue Linked, Stichting de Noordzee en de Dutch Shark Society werken samen aan het programma 'Haaien en roggen terug in de Noordzee'. SVNL heeft namens deze organisaties Wageningen Marine Research (WMR) verzocht om een habitatgeschiktheidsanalyse van de Oosterschelde en de Voordelta voor de stekelrog (Raja clavata) uit te voeren. De belangrijkste vragen zijn of stekelroggen in de beide gebieden een deel van hun levenscyclus kunnen leven en of er ook een schatting is te geven voor het huidige en toekomstige aantal (dichtheid) stekelroggen per oppervlakte-eenheid in het gebied. Met het resultaat van deze studie proberen de bovengenoemde organisaties duidelijkheid te krijgen over het perspectief van het uitzetten van in het laboratorium gekweekte stekelroggen (Figuur 1) in de Oosterschelde en de Voordelta als bijdrage aan de ontwikkeling van een duurzame stekelrogpopulatie in deze gebieden. De stekelrog komt in de laatste decennia zeer sporadisch voor in de Oosterschelde en Voordelta, terwijl de soort in het begin van de twintigste eeuw veelvuldig werd aangetroffen (ICES, 2016; Squotti et al., 2016). In een habitatgeschiktheidsanalyse wordt nagegaan welke eisen de stekelrog stelt aan zijn leefomgeving en of daaraan wordt voldaan in de Oosterschelde en de Voordelta. Hierbij worden abiotische en biotische omgevingsfactoren betrokken. De eventuele effecten van menselijke activiteiten, zoals visserij en zandsuppleties, worden in dit rapport buiten beschouwing gelaten. Met onderhavige studie wordt aangesloten bij de IUCN/SSC richtlijnen voor herintroductie en andere beschermingsverplaatsingen van soorten (IUCN/SSC, 2013). In Bijlage 1 is een korte selectie van de voor deze studie meest relevante punten uit die richtlijnen opgenomen. Deze hebben betrekking op de eisen die worden gesteld aan de haalbaarheid en opzet van een vrijlating van exemplaren in een gebied, alsmede de benodigde type biologische kennis en de aanbevelingen voor en eisen aan monitoring van de vrijgelaten exemplaren na de vrijlating.

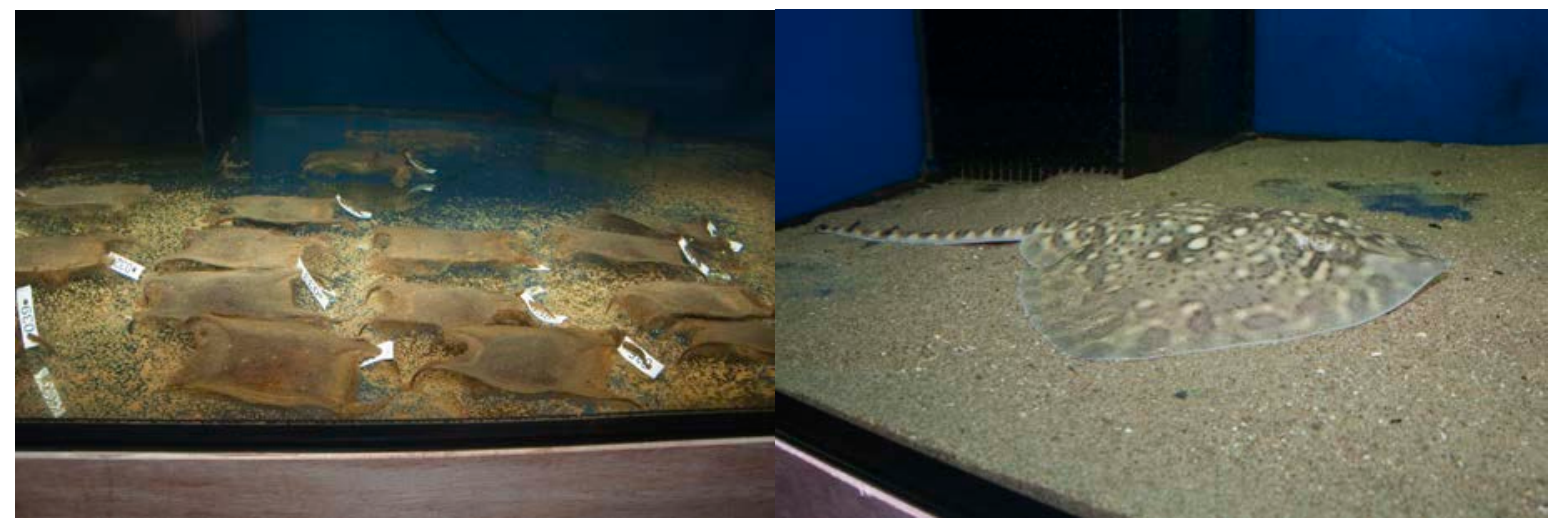

Figuur 1 Eikapsels van de stekelrog (links) en juveniele stekelrog (rechts) in het laboratorium van Blue Linked. Foto's: P. Verhoog (WNF)

\subsection{Afbakening}

WMR geeft hier geen advies over het wel of niet uitzetten van de gekweekte stekelroggen.

Deze deskstudie is een eerste schatting van de habitatgeschiktheid voor de stekelrog en beperkt van omvang omdat hiervoor weinig data beschikbaar zijn.

Er is geen habitatmodel voor de stekelrog opgesteld omdat daarvoor essentiële data ontbreken. 


\subsection{Aanpak}

Om de kennisvraag te beantwoorden, is de volgende werkwijze toegepast:

\begin{tabular}{|c|l|l|}
\hline Stap & Doel & Werkwijze \\
\hline 1 & $\begin{array}{l}\text { Onderzoek naar huidige aanwezigheid } \\
\text { stekelroggen in surveys en visserij in het } \\
\text { gebied }\end{array}$ & $\begin{array}{l}\text { Extractie gegevens van meerdere surveys en uit } \\
\text { de VISSTAT database }\end{array}$ \\
\hline 2 & $\begin{array}{l}\text { Habitatkenmerken verspreidingsgebied } \\
\text { stekelrog vaststellen }\end{array}$ & Literatuuronderzoek en raadplegen experts \\
\hline 3 & $\begin{array}{l}\text { Habitatkenmerken Oosterschelde en } \\
\text { Voordelta vaststellen }\end{array}$ & $\begin{array}{l}\text { Verzamelen kaarten en gepubliceerde gegevens } \\
\text { en raadplegen van experts }\end{array}$ \\
\hline 4 & $\begin{array}{l}\text { Kwalitatieve beoordeling } \\
\text { habitatgeschiktheid Oosterschelde en } \\
\text { Voordelta voor stekelrog }\end{array}$ & $\begin{array}{l}\text { Synthese met verzamelde gegevens uit } \\
\text { bovenstaande onderdelen en afstemmen met } \\
\text { experts }\end{array}$ \\
\hline
\end{tabular}

Het team dat de opdracht heeft uitgevoerd, bestond uit een aantal personen van WMR, almede uit twee externe experts, dr. Henk Heessen en dr. Paddy Walker.

\begin{tabular}{|l|l|l|}
\hline Teamleden/ experts & Organisatie & Expertiseveld \\
\hline Ruud J ongbloed & WMR & Integratie en coördinatie (projectleider) \\
\hline Harriet van Overzee & WMR & Aanlandingsgegevens \\
\hline Ralf van Hal & WMR & Surveys \\
\hline Erwin Winter & WMR & Ecologie en gedrag van vis \\
\hline Johan Craeymeersch & WMR & Habitat Voordelta \\
\hline Jeroen Wijsman & WMR & Habitat Oosterschelde \\
\hline Henk Heessen & $\begin{array}{l}\text { Geen (vroeger: RIVO en } \\
\text { IMARES) }\end{array}$ & $\begin{array}{l}\text { Ecologie en verspreiding van beenvissen en } \\
\text { kraakbeenvissen }\end{array}$ \\
\hline Paddy Walker & $\begin{array}{l}\text { Hogeschool Van Hall } \\
\text { Larenstein, Nederlandse } \\
\text { Elasmobranchen } \\
\text { Vereniging }\end{array}$ & Ecologie en verspreiding van kraakbeenvissen \\
\hline
\end{tabular}

Experts zijn door de projectleider gericht benaderd om informatie en advies te geven.

Deze deskstudie bestaat uit literatuur- en bronnenonderzoek waarvoor gebruik is gemaakt van WMRdatabases en diverse recente rapportages en wetenschappelijke publicaties. Verder is gebruik gemaakt van informatie over historische en recente verspreiding van de stekelrog in de Noordzee. Uit deze gegevens kan worden afgeleid welke omgevingsfactoren van belang zijn voor de stekelrog en of die momenteel heersen in de Oosterschelde en de Voordelta, waardoor er een voorspelling kan worden gegeven van de habitatgeschiktheid van de Oosterschelde en de Voordelta voor de stekelrog.

\subsection{Studiegebied}

Het studiegebied omvat de Voordelta en de Oosterschelde. Bij de bespreking van de historische verspreiding en van de huidige habitatgeschiktheid wordt ook het gebied meegenomen dat verder zeewaarts (tot $20 \mathrm{~m}$ diepte) reikt, evenals het gebied dat grenst aan de zuidzijde van de Voordelta voor de monding van de Westerschelde op de overgang naar open zee. Dit laatste gebied is Natura 2000-gebied de Vlakte van de Raan. De Voordelta en de Oosterschelde zijn fysiek met elkaar verbonden, zijn onderdeel van de Zeeuwse Deltawateren en zijn beide Natura 2000-gebieden vanwege hun grote beschermingswaarde. De kenmerken van deze gebieden worden in de secties 1.4.1 en 1.4.2 beschreven. Aanlandingsgegevens van stekelroggen zijn geanalyseerd op de schaal van ICESkwadranten, waarbij een 4-tal ICES kwadranten relevant is voor het studiegebied (zie Figuur 2). 


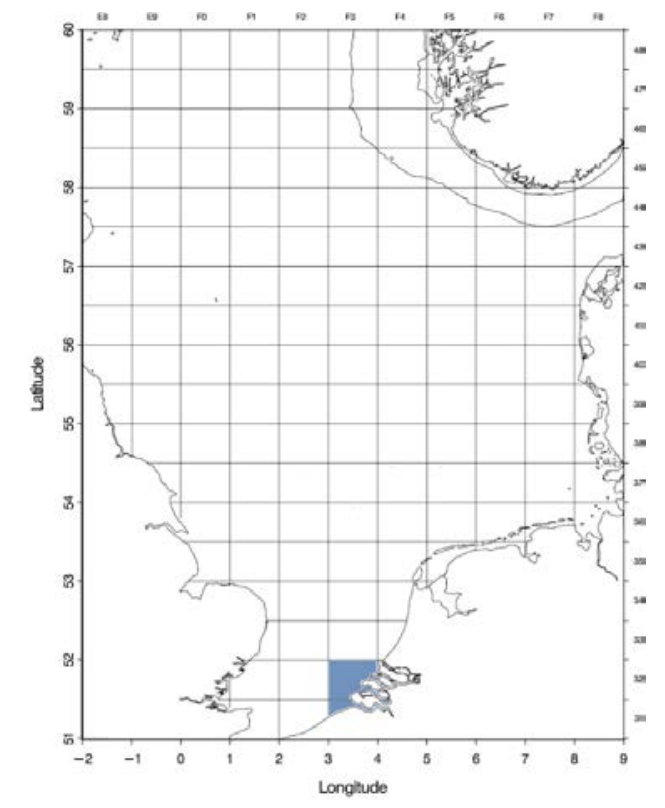

Figuur 2 De vier ICES-kwadranten 31F3, 32F3, 31F4, 32F4 (blauw gearceerd gebied) waarin Oosterschelde en Voordelta liggen.

\subsubsection{Voordelta}

De Voordelta is het kustgebied voor de Zuid-Hollandse en Zeeuwse eilanden in de Noordzee. Het

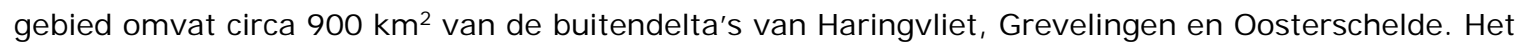
betreft ruwweg het gebied vanaf de Nieuwe Waterweg tot de Westerscheldemonding. Aan de zeezijde volgt de grens de doorgaande 20 meter dieptelijn en ligt bijna tegen de 6 mijllijn aan (Figuur 3). De Voordelta is sinds 2008 een Natura 2000-gebied en het grootste deel (ruim 87.000 ha) is gekarakteriseerd als $\mathrm{H} 1110$, permanent overstroomde zandbanken. Een klein deel (ongeveer 2.200 ha) bestaat uit slik- en zandplaten. Door de ligging voor de Zuid-Hollandse en Zeeuwse delta wijkt het gebied af van de kustwateren die verder noordelijk voor de Hollandse kust liggen. Het gebied wordt gekenmerkt door de aanwezigheid van een gevarieerd en dynamisch milieu van kustwateren, intergetijdengebied (zandplaten en slikken) en stranden, die een relatief beschutte overgangszone vormen tussen de (voormalige) estuaria en de volle zee.
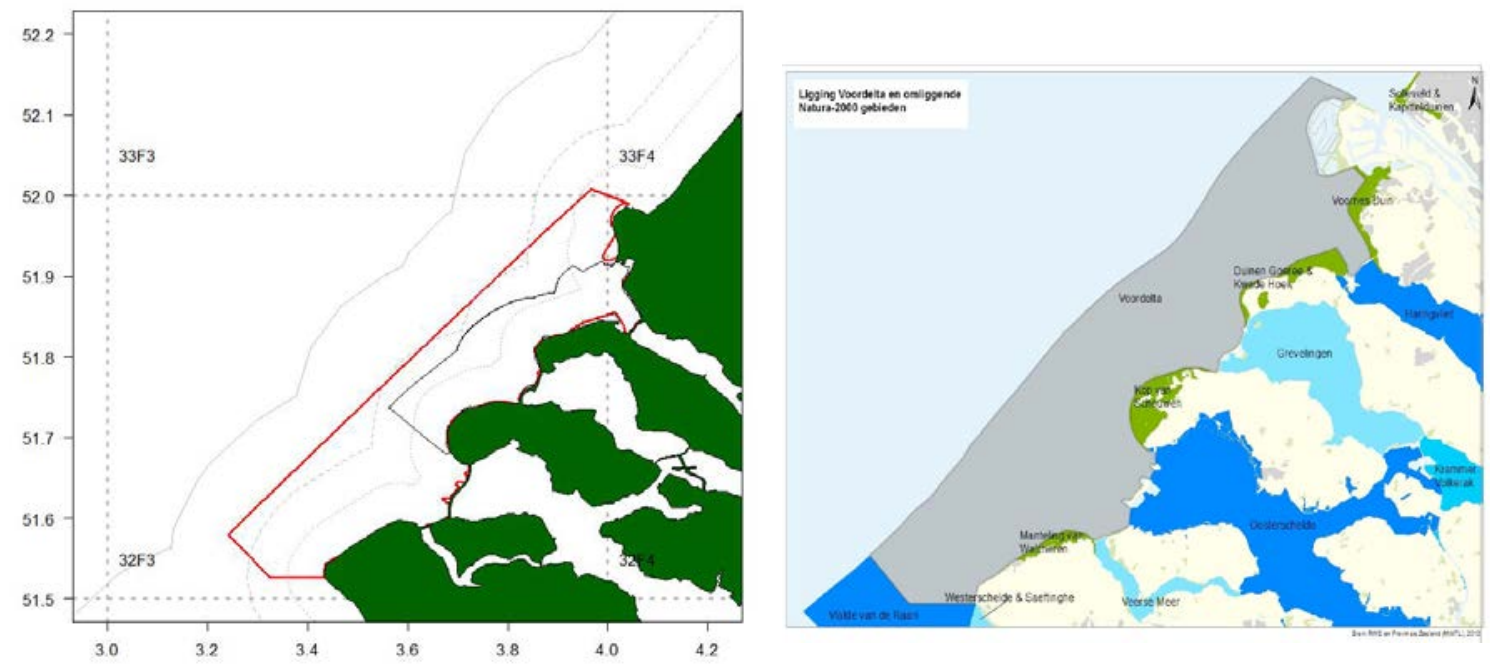

Figuur 3 Linker kaart: De Voordelta (in rood) en het Bodembeschermingsgebied (in zwart), in relatie tot de ICES-kwadranten (de grote vierkanten). De Voordelta ligt hoofdzakelijk in ICES-kwadrant 32F3 en de 12-mijlgrens (doortrokken grijze lijn), de 6-mijlgrens (gestreepte grijze lijn) en de 3-mijlgrens (gestippelde grijze lijn). Rechter figuur: De ligging van Voordelta en omliggende Natura 2000-gebieden. 


\subsubsection{Oosterschelde}

De Oosterschelde is een grootschalig getijdenlandschap met een grote mate van natuurlijkheid. De Oosterschelde is van de zee afgesloten door een stormvloedkering, die de getijdenwerking nog in zekere mate toelaat. Als gevolg van de getijdenstromen vinden erosie- en sedimentatieprocessen plaats die resulteren in een wisselend patroon van schorren, slikken en droogvallende platen (het intergetijdengebied) met een vaak grillige structuur, ondiep water en diepe getijdengeulen. In de monding van de Oosterschelde bevinden zich de diepste stroomgeulen die plaatselijk een diepte bereiken van 45 meter. Tussen deze stroomgeulen en in het gebied ten oosten van de Zeelandbrug bevinden zich uitgestrekte gebieden met ondiepe wateren met zandbanken. In het oosten en noorden van het gebied komen grote oppervlakten slikken voor. Het water, het intergetijdengebied en de binnendijks gelegen gebieden vormen tezamen een grote variatie aan milieutypen. Deze variatie wordt bepaald door factoren als getij, stroming, watertemperatuur, zoutgehalte, vochthuishouding, hoogteligging, waterkwaliteit en sedimentsamenstelling (Ministerie LNV, 2009). Kaarten van de Oosterschelde met de droogvalduur en de ecotopen zijn te vinden in respectievelijk Figuur 4 en Bijlage 15.

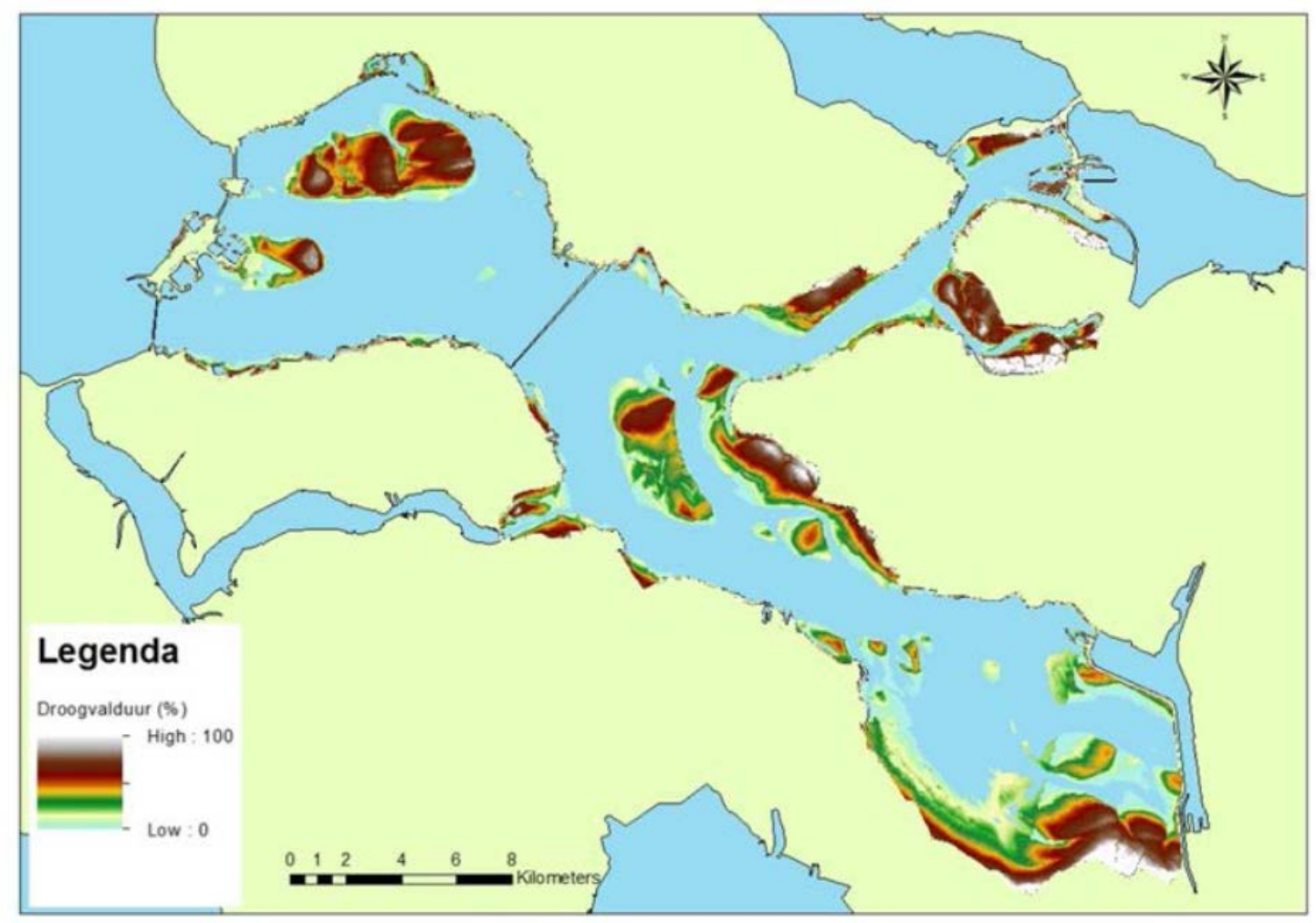

Figuur 4 De Oosterschelde met aanduiding van de droogvalduur. Bron: Henkens et al. (2012).

\subsection{Opbouw rapport}

In dit rapport wordt in hoofdstuk 2 een korte schets gegeven van de biologie en verspreiding van de stekelrog in de Noordzee vanaf 1900 . Hierbij is geen compleetheid nagestreefd. Het voorkomen van stekelroggen in de beide studiegebieden Voordelta en de Oosterschelde gedurende de laatste decennia wordt gegeven in hoofdstuk 3. Hiervoor zijn extracties gedaan uit databases met aanlandingsgegevens van de Nederlandse visserij, alsmede van diverse demersale surveys van WMR. In hoofdstuk 4 worden de resultaten van een literatuurstudie naar de habitateisen van stekelroggen in de Noordzee en enkele andere zeeën beschreven en geëvalueerd om te komen tot een set van algemeen geldende (geharmoniseerde) kennisregels voor de omgevingsfactoren die de habitateisen voor de stekelrog vormen. De toetsing van de waarden van de omgevingsfactoren van Oosterschelde en Voordelta aan de set van geharmoniseerde kennisregels voor habitateisen van de stekelrog is uitgevoerd in hoofdstuk 5. De informatie die is verzameld voor de betreffende omgevingsfactoren in de Oosterschelde en Voordelta is globaal en is weergegeven in de vorm van ruimtelijke kaarten en 
grafieken. Deze habitatgeschiktheidsanalyse is een eerste beoordeling en geen uitgebreide habitatmodellering. Een discussie over verschillende aspecten van deze analyse en hun beperkingen wordt gepresenteerd in hoofdstuk 6. De conclusies en aanbevelingen worden gepresenteerd in hoofdstuk 7 . 


\section{Biologie en verspreiding van de stekelrog}

In dit hoofdstuk wordt een kort overzicht gegeven van de biologie en de verspreiding, inclusief de migratie, van de stekelrog in de Noordwest Europese zeeën vanaf 1900. Hierbij is geen compleetheid nagestreefd. Een deel van deze informatie is van belang bij de beoordeling van de potentiele habitatgeschiktheid van de stekelrog in de Oosterschelde en de Voordelta (hoofdstuk 5).

\subsection{Ecologie van de stekelrog}

De stekelrog heeft als vissoort een lage groeisnelheid, lage vruchtbaarheid en een hoge leeftijd voor het bereiken van volwassenheid. Deze eigenschappen maken deze soort gevoelig voor verhoogde mortaliteit, door bijvoorbeeld visserij (Heessen et al., 2015; Walker \& Kingma, 2013). De stekelrog is geclassificeerd als bijna bedreigd (near threatened) in de IUCN database (Ellis et al., 2016).

De stekelrog is een epibenthische kraakbeenvis die het grootste deel van de tijd gedeeltelijk is ingegraven in de bodem.

In experimenten met gemerkte stekelroggen, uitgevoerd tussen 1959 en 1976, zijn verspreiding en bewegingen van stekelroggen geanalyseerd en beschreven door Walker et al. (1997). Zij vonden dat stekelroggen in de Noordzee behoorden tot één bestand en die in het Kanaal tot een ander bestand. $\mathrm{Na}$ vrijlating bleven de gemerkte stekelroggen binnen ca. 30-50 zeemijl in de Noordzee en binnen ca. 10-15 zeemijl in het Kanaal. Adulte stekelroggen migreren van offshore, relatief diep (ca. $30 \mathrm{~m}$ ) water in de winter naar inshore, ondiep (ca. $10 \mathrm{~m}$ ) water in de zomer, waarschijnlijk voor de voortplanting.

Belangrijke eigenschappen van de stekelrog zijn samengevat door Walker \& Kingma (2013) en overgenomen in onderstaande tabel.

\begin{tabular}{|l|l|}
\hline Latijnse naam & Raja clavata \\
\hline Nederlandse naam & Stekelrog \\
\hline Lengte (geboren) $(\mathrm{cm})$ & $11-13$ \\
\hline Max lengte volwassen $(\mathrm{cm})$ & 130 \\
\hline Verspreiding & Bijna overal \\
\hline Habitat & Kustwateren \\
\hline Indeling & Demersaal \\
\hline Dieet & Kreeftachtigen en vissen \\
\hline Migratie & Seizoensgebonden migratie \\
\hline Voortplanting & Ovipaar \\
\hline Duur draagtijd (maanden) & $4-6$ \\
\hline Aantal jongen & $48-78$ \\
\hline Volwassen drempel (jaar) & $7-9$ \\
\hline Bevissing & Commercieel en recreatief bevist \\
\hline
\end{tabular}




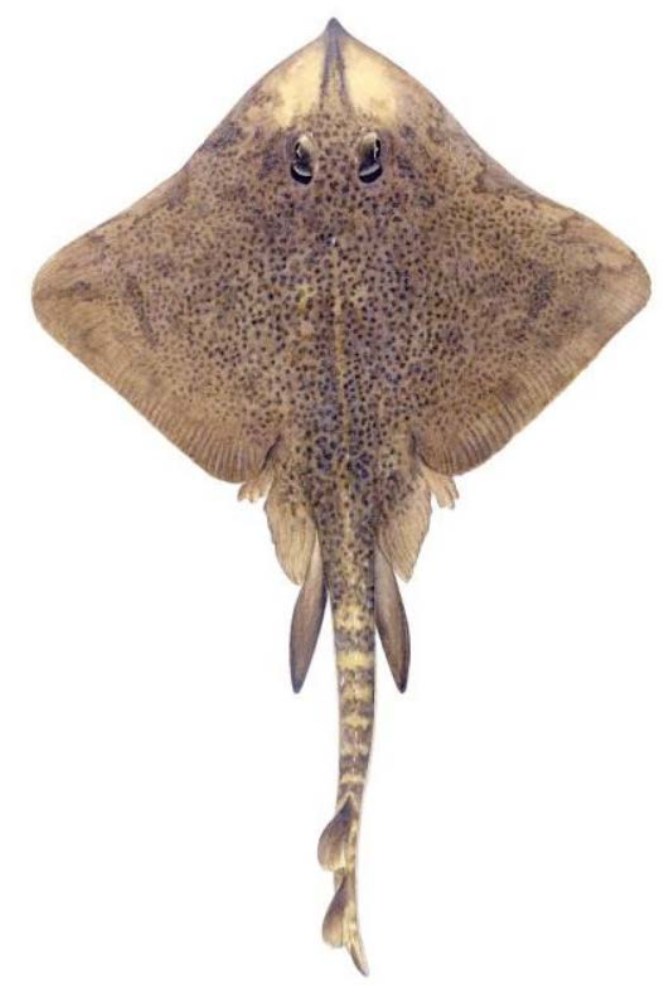

Figuur 5 Stekelrog (Raja clavata) Bron: Walker et al. (2015)

\subsection{Historische verspreiding van de stekelrog in de Noordzee}

Een historisch overzicht wordt gegeven in een ecoprofiel voor roggen in de Noordzee (Walker, 1996). Halverwege de vorige eeuw trad een afname van de stekelrog op (Walker \& Heessen, 1996). De Zuiderzee was het belangrijkste paai- en opgroeigebied voor de stekelrog van de Nederlandse wateren. In de Nederlandse kustwateren en zuidelijke estuaria werden vroeger voornamelijk stekelroggen (90\%) en pijlstaartroggen (10\%) gevangen. De Zeeuwse estuaria waren belangrijker dan die in Zuid-Holland of de Waddenzee (Walker, 1996). De visserij vond voornamelijk plaats gedurende de lente en de zomer, waarna de roggen naar dieper water migreerden. De achteruitgang in aantallen voltrok zich hier later dan in de Waddenzee. Tot de jaren zestig werd gevist op stekelrog, maar tussen 1979 en 1985 werden in Zeeuwse estuaria geen stekelroggen meer gevangen door beroepsvissers (Walker \& Kingma, 2013).

Tegenwoordig concentreert de stekelrog zich in het zuidwestelijk deel van de Noordzee. De abundantie aldaar is toegenomen in de afgelopen 5 jaar (Walker \& Kingma, 2013; Sguotti et al., 2016). ICES (2016) concludeert dat de stekelrog hoofdzakelijk stabiel/toenemend is in recente jaren wanneer wordt uitgegaan van visserij onafhankelijke gegevens van de International Bottom Trawl Survey (IBTS) in winter en zomer, en van verschillende boomkorsurveys (in zomer).

Sguotti et al. (2016) bestudeerden langetermijnveranderingen in de verspreiding en abundantie van roggen in de zuidelijke Noordzee, gebaseerd op extensieve historische tijdseries (1902-2013) van visserij-onafhankelijke survey data. De stekelrog vertoonde over die periode een significante afname. Binnen de Noordzee was de dichtheid hoger in het zuidwestelijke en noordwestelijke deel ten opzichte van het oostelijke deel (zie Figuur 6). De Zeeuwse deltawateren vallen onder het oostelijke deel. Dit is in overeenstemming met de constateringen van de ICES Working Group on Elasmobranch Fishes (ICES, 2016) dat de stekelrog in de eerste decennia van de 20ste eeuw breder verspreid was over de zuidelijke Noordzee, met hoge abundantie in de zuidwestelijke Noordzee en in de Duitse Bocht, ten noorden van Helgoland. De soort is verdwenen uit de zuidoostelijke Noordzee (Duitse Bocht), en vangsten in de Zuidelijke Bocht zijn beperkt tot het westelijke deel. 

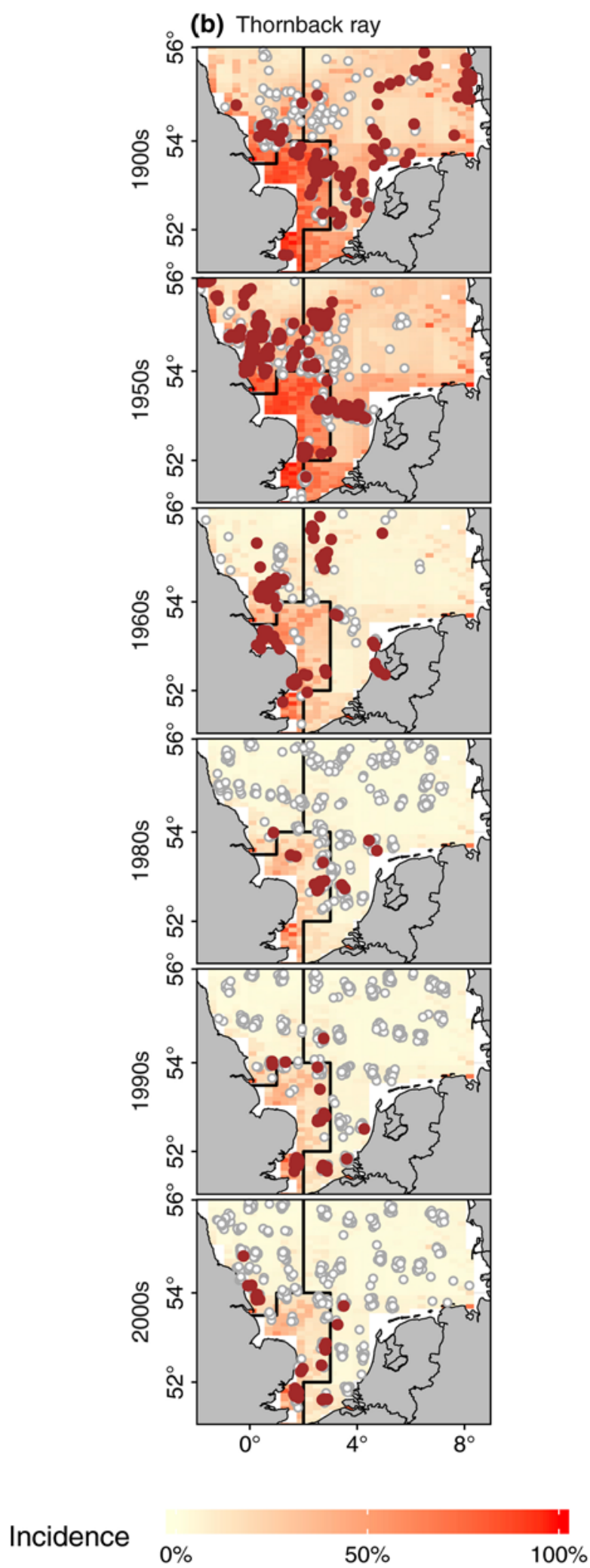

Figuur $6 \quad$ Veranderingen in gemodelleerde ruimtelijke verspreiding van stekelrog op de Noordzee. Kaarten tonen de voorspelde verspreidingspatronen in zes goed bemonsterde decennia: symbolen representeren survey trekken (rood gevuld als tenminste 1 individu was gevonden, anders ongevuld) en graduele achtergrond kleuren tonen het voorspelde voorkomen. Bewerking van een kaart uit Sguotti et al. (2016). 


\subsection{Recente verspreiding van de stekelrog op de internationale Noordzee}

Het verspreidingsgebied en abundantie van de stekelrog is gedurende de laatste eeuw afgenomen, met een resterende concentratie in de zuidwestelijke Noordzee en een uitbreiding tot in het Kanaal zie Figuur 7). In recente jaren zijn de survey catch trends in ICES Divisies 4.c (Zuidelijke Noordzee) en 7.d (Oostelijke Kanaal) stabiel/toenemend. De status in Divisies 4.a-b is onzeker (ICES, 2016).

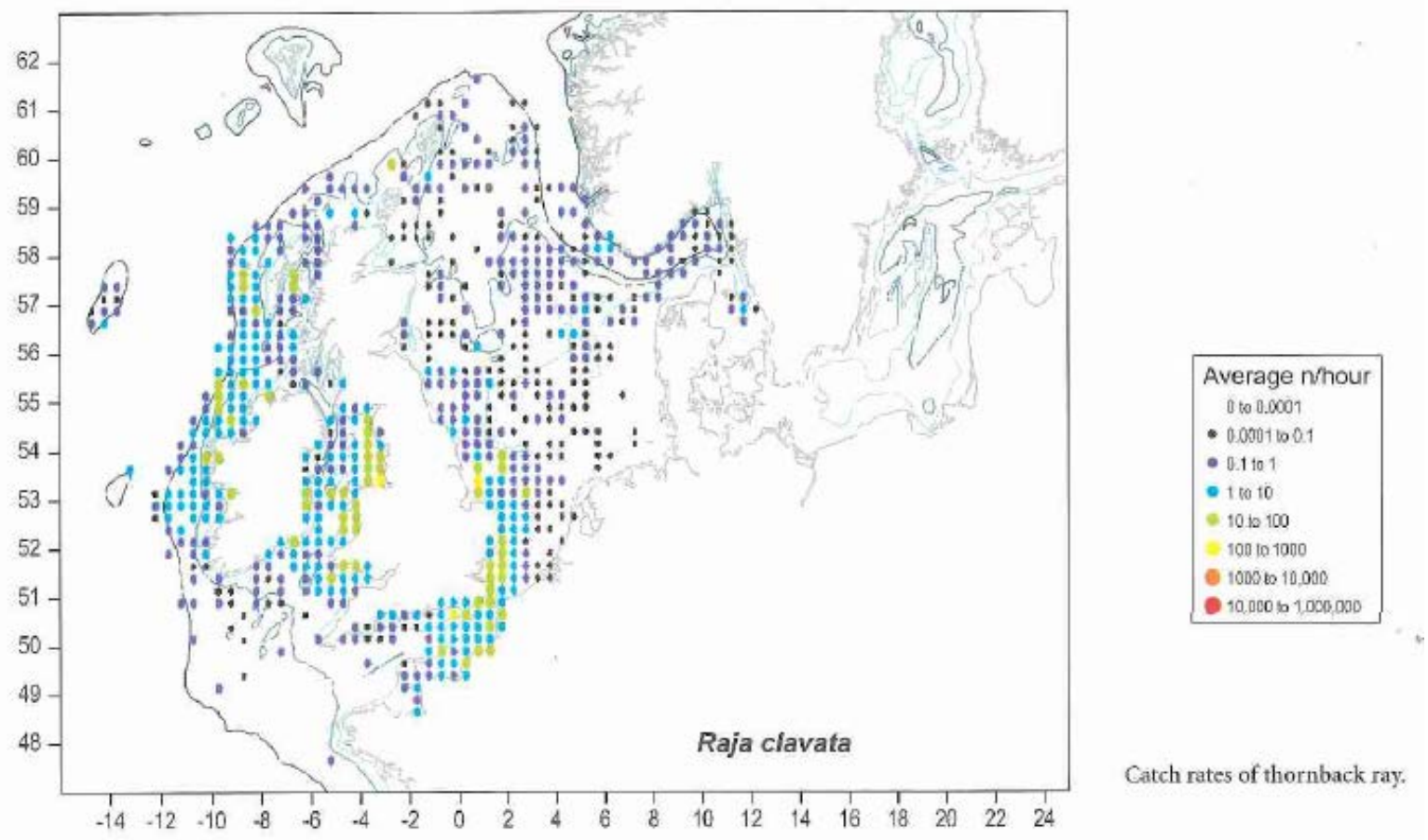

Figuur 7 Vangst (in gemiddeld aantal per uur) van stekelrog in surveys in de ecoregio's Noordzee, Keltische Zee, Oostzee, in de periode 1977-2013. Bron: Heessen et al. (2015)

\subsection{Migratie van de stekelrog}

Er zijn verschillende experimenten uitgevoerd naar de ruimtelijke en temporele verspreiding en eventuele seizoenmigratie van stekelroggen in en rond de Noordzee (Walker et al., 1997; Hunter et al. 2005; Chevolot et al., 2006; Humphries et al., 2016). Hierbij zijn de stekelroggen gemerkt met conventionele externe merken of met data storage tags (DST). De DST geven veel gedetailleerdere informatie over de migratieafstanden. Er treedt seizoenmigratie op, waarbij het overgrote deel van de stekelroggen binnen enkele tientallen kilometers blijft van de locatie waar de roggen waren gemerkt (het Theems estuarium: Walker et al., 1997; Hunter et al., 2005). Een klein deel maakt echter lange tochten, meestal tot $130 \mathrm{~km}$ of soms veel meer. Dit laatste bleek uit een individuele stekelrog die in het Theems estuarium was gemerkt met een DST en in de herfst migreerde naar het zuidelijke deel van de centrale Noordzee en daar rondzwierf. In het voorjaar keerde deze rog terug naar het Theems estuarium om te paren (Hunter et al., 2005). De afstanden die deze rog aflegde tijdens de migratie waren dus aanzienlijk. Met name de DST-studies met individuele stekelroggen maken duidelijk dat er seizoenmigratie optreedt met de tendens om terug te keren naar belangrijke habitats voor paren en het afzetten van de eieren (Heessen et al., 2015). Het is dus de vraag of de Voordelta en de Oosterschelde gebieden zijn of kunnen worden die ook de rol van die belangrijke habitats kunnen spelen. 


\subsection{Habitateisen}

Estuaria en kustgebieden zijn belangrijke habitats voor vele soorten haaien en roggen. Factoren die habitats minder geschikt kunnen maken zijn onder andere: infrastructurele werken, eutrofiering, verlies aan biobouwers, zoals zeegras en mosselbanken (Walker et al., 2015).

Er zijn bij roggen drie levensfasen te onderscheiden die specifieke eisen aan ecologische habitats stellen: (a) eileggebieden; (b) kinderkamergebieden; (c) gebieden voor grote samenscholingen voor foerageren en paren. Er is weinig bekend over de eileggebieden, alhoewel zich in delen van de zuidelijke Noordzee, zoals het Theems estuarium, grote aantallen juveniele stekelroggen bevinden en daardoor eileggebieden worden verwacht in het buiten Theems estuarium en The Wash (Walker, 1996). De exacte habitateisen van elk van deze drie specifieke habitats zijn dus niet bekend. Dat betekent dat de Oosterschelde en Voordelta niet kunnen worden beoordeeld op geschiktheid voor eileglocaties, opgroeilocaties, samenscholingslocaties voor voortplanting of foerageren.

Stekelroggen komen voor binnen bepaalde grenzen aan abiotische factoren (bodemdynamiek, waterdiepte, saliniteit, watertemperatuur, stroomsnelheid (i.v.m. retentie van eikapsels en juvenielen) en biotische factoren (voldoende voedsel, zoals kreeftachtigen, weinig predatie, weinig uitval door ziektes, populatie groot genoeg voor voldoende reproductie). Op basis van de habitateisen van de stekelrog, en de habitatkarakteristieken van de Oosterschelde en Voordelta, is nagegaan wat de mogelijkheden zijn voor de ontwikkeling van een stekelrogpopulatie in die gebieden.

Bodemdynamiek en stroomsnelheid en de aanwezigheid van structuren op de bodem zijn waarschijnlijk belangrijke factoren voor de overleving van eikapsels en jongen van roggen. Onder deze omstandigheden is de kans op het wegspoelen van de eikapsels en de jongen kleiner. Bovendien is er dan meer bescherming tegen predatoren.

Vier life-history-processen bepalen in belangrijke mate de voorwaarden voor een duurzame ontwikkeling van een populatie van de stekelrog: overleving, groei, reproductie en rekrutering. Er is echter nog erg weinig bekend over de invloed van habitatkenmerken op deze life-history-processen. Onderhavige studie heeft zich daarom alleen gericht op de verspreiding en abundantie van stekelroggen en de relatie met abiotische en biotische omgevingsfactoren.

\subsection{Modellen voor habitatgeschiktheid}

Er zijn veel methoden voor het genereren van habitatgeschiktheidskaarten. Deze methoden kunnen worden ingedeeld in 2 groepen: 'data based'(data-gebaseerd) voor 'response curves' (responscurves) en 'knowledge based' (kennis-gebaseerd) voor 'knowledge rules' (kennisregels). Alle habitatgeschiktheidskaarten zijn afhankelijk van de kwaliteit van de kaarten van de milieufactoren waarop deze moeten worden gebaseerd (Schellekens et al., 2012).

Er zijn verschillende modellen beschikbaar waarmee voor soorten de habitatgeschiktheid kan worden afgeleid en voorspellingen kunnen worden gemaakt van potentiele dichtheden in gebieden. Vaak worden Generalised Linear Modes (GLM) en Additive Models (GAMs) toegepast. Boosted Regression Trees (BRTs) zijn volgens Dedman et al. (2015) geschikter voor data-arme soorten, zoals de stekelrog. In onderhavige studie zal geen onderscheid worden gemaakt tussen het soort modellen dat is toegepast voor de analyse van de gegevens voor de stekelrog.

Habitatgeschiktheidsmodellen hebben een aantal beperkingen, vooral voor meer mobiele soorten zoals vissen en zeezoogdieren (Glorius et al., 2012). Er wordt in dergelijke modellen geen rekening gehouden met processen die variëren in de tijd, zoals kolonisatietijd en populatiedynamiek, alsmede de invloed van predatie of competitie of een gebrek aan voedselsoorten. Dit zal ook gelden voor de stekelrog, waarbij het de vraag is hoe mobiel deze soort is en hoe groot de invloed daarvan kan zijn.

Er zijn in ieder geval twee verschillende modelbenaderingen beschikbaar om habitatkwaliteit voor vissoorten met verschillende levensstadia te schatten: 1) Habitat Suitability Index (HSI) Modelling en 2) Dynamic Energy Budget (DEB) Modelling. Dit is bijvoorbeeld toegepast voor de steur (Winter et al., 
2015). De keuze voor de modellen zal afhangen van de databeschikbaarheid voor omgevingsparameters en van habitateisen, die kunnen variëren tussen de verschillende regio's en levensstadia. Voor de voorspelling van het potentiele groeihabitat voor stekelrog kan een fysiologisch model (Dynamic Energy Budget: DEB) worden gekoppeld aan een ecosysteem model (GETM-ERSEM). Voor een gedetailleerde beschrijving van de modellen en hun gebruik wordt verwezen naar Teal et al. (2015).

In onderhavige studie zijn veel gegevens betrokken uit publicaties waarin alle bovengenoemde methoden en modellen, behalve de Dynamic Energy Budget (DEB) Modelling, zijn gebruikt. Er is in deze studie geen modellering uitgevoerd met deze methoden en modellen van de habitatgeschiktheid van de Oosterschelde en de Voordelta voor de stekelrog. Er zijn daarvoor naar verwachting te weinig data beschikbaar en de studie is beperkt van opzet, zoals al is aangeduid in paragraaf 1.2. 


\section{$3 \quad$ Vangsten van stekelroggen in Noordzee, Oosterschelde en Voordelta}

In dit hoofdstuk worden resultaten over roggen gepresenteerd uit databestanden met de aanlandingen van de Nederlandse vissersvloot en van diverse soorten surveys met onderzoeksvaartuigen in de Nederlandse kustwateren. Hierbij is een selectie gemaakt op de stekelrog en het gebied waarin de Oosterschelde en de Voordelta vallen.

De stekelrog valt, net zoals enkele andere roggensoorten, onder de Visserijwet 1963. ICES geeft adviezen over de vangstmogelijkheden voor de Europese vloot op roggen als groep, de zg. Total Allowable Catch (TAC) (ICES, 2016). Er is geen gerichte commerciële visserij op roggen in Nederlandse wateren. Roggen worden wel als waardevol beschouwd en aangeland (Walker en Kingma, 2013). Nederland heeft een roggenquotum, dat een bijvangstquotum is. Stekelrog mag worden aangeland, met verplichte vermelding in het logboek. Het roggenquotum is restrictief, waardoor slechts een deel van alle vangsten wordt aangeland en de rest wordt teruggegooid in zee (discarding) (Walker et al., 2015). Sinds 1 januari 2016 is de aanlandplicht voor de demersale vloot in werking getreden en vanaf 2019 zal het discarden van roggen worden verboden (EC, 2017).

\subsection{Nederlandse aanlandingsgegevens (VISSTAT)}

\subsubsection{Methode}

In het officieel Visserij Registratie Informatie Systeem (VIRIS) van het Ministerie van Economische Zaken staan aanlandingen van commerciële soorten geregistreerd per schip, reis, gebied (ICES kwadrant) en gebruikt vistuig. Vissers registreren dit soort gegevens in verplichte EU-logboeken en leveren ze wekelijks in. De aanlandingen- en inspanningsregistratie is bedoeld voor visserijbeheer en het uitvoeren en handhaven van quoteringen. Daarnaast zijn de gegevens ook beschikbaar voor onderzoek. WMR heeft de beschikbare gegevens opgeslagen in haar VISSTAT database.

\subsubsection{Selectie van gegevens}

Aangezien het voor de visserij sinds 2008 verplicht is om het gewicht van roggen per soort te vermelden bij aanlandingen, zijn voor deze rapportage de aanlandingsgegevens van alle roggensoorten uit de database geëxtraheerd. Roggen aanlandingsgegevens zijn beschikbaar voor de periode 1967-1983 ${ }^{1}$ en 1998-2016. Daarbij moet worden opgemerkt dat de gegevens van 1979 en 1981 onvolledig zijn. Om (stekel)rog gegevens over de Voordelta en Oosterschelde te verkrijgen zijn de volgende selectiecriteria op de gegevens toegepast:

1. Alleen Nederlandse schepen

2. Alle roggensoorten

3. De ICES-kwadranten 31F3, 32F3, 31F4, 32F4 (Figuur 2) ${ }^{2}$

\footnotetext{
${ }^{1}$ Als gevolg van een recentelijk uitgevoerde kwaliteitscontrole op de aanlandingsgegevens van de periode 1967-1983 wijken de gepresenteerde gegevens voor deze periode in voorliggend rapportage enigszins af van de gegevens gepresenteerd in Van Overzee et al. (2014).

${ }^{2}$ De ruimtelijke aanlandingsgegevens voor de periode 1967-1983 moeten met voorzichtigheid geïnterpreteerd worden; indertijd werden de bijvangstgegevens namelijk aan het kwadrant toegekend waar de meeste vis gevangen was per reis (Van Overzee et al., 2014).
} 
Daarnaast zijn de vangst- en inspanningsgegevens gebruikt om het gemiddeld aanlandingssucces (LpUE - Landings per Unit Effort) voor roggen voor de Nederlandse vloot vissend met sleepnetten en zegen te berekenen. Ruimtelijke patronen in het gemiddeld aanlandingssucces voor de aflopen zes jaar worden in voorliggend rapport gepresenteerd.

\subsubsection{Resultaten}

De Nederlandse aanlandingsgegevens in het studiegebied (d.w.z. ICES-kwadranten 31F3, 32F3, 31F4, 32F4) zijn per soort(groep) weergegeven in Figuur 9. In Figuur 8 worden de totale Nederlandse aanlandingsgegevens van roggen gepresenteerd. Opvallend is dat aanlandingen uit het studiegebied in de periode 1967-1983 over het algemeen hoger zijn dan in de periode 1998-2016. Aanlandingen zijn voornamelijk afkomstig uit ICES-kwadranten 31F3 en 32F3 (Figuur 10). Dit zijn de westelijk gelegen kwadranten. De gegevens laten tevens zien dat de relatieve bijdrage van de Nederlandse roggenaanlandingen in het studiegebied t.o.v. de totale Nederlandse roggenaanlandingen varieerde tussen $0,1 \%-13,5 \%$ voor de periode $1967-1983$ en tussen $0,1 \%-1,9 \%$ voor de periode 1998-2016 (Tabel 1 en Tabel 2).

Vanaf 2008 is de visserij verplicht om het gewicht van roggen per soort te vermelden. Sinds deze verplichting is het mogelijk om specifiek ontwikkelingen in aanlandingen van stekelrog in het studiegebied te volgen. De aanlandingen van roggen uit het studiegebied bestonden voor de periode 2008-2016 voor 38\%-58\% uit stekelrog. Hierbij is het wel de vraag hoe accuraat de soortidentificatie is en in hoeverre dit verbeterd moet worden (ICES, 2016).

Het gemiddelde aanlandingssucces (LpUE - Landings per Unit Effort) in de Noordzee in de periode 2011-2016 is het hoogst voor de Oost-Engelse kust in de strook die noord tot zuid loopt van de estuaria van de Humber, The Wash en de Theems tot de straat van Dover. De laatste jaren neemt de LpUE af voor de Oost Engelse kust, terwijl deze toeneemt ten noorden van de Nederlandse en Duitse Waddeneilanden, zoals met name te zien is voor 2015 en 2016 (Figuur 11). 
Roggen aanlandingen Nederlandse schepen

800

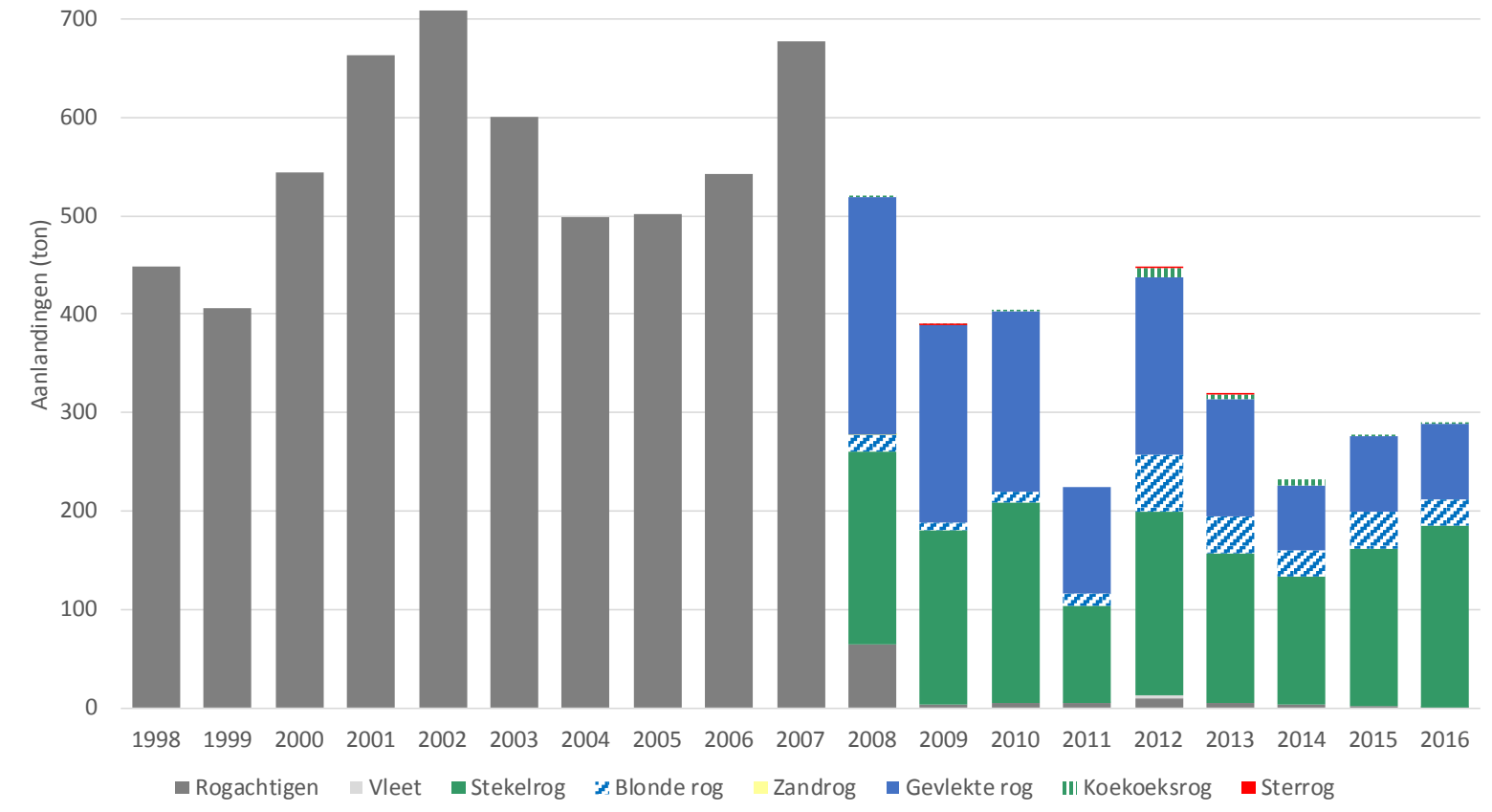

Figuur $8 \quad$ Nederlandse aanlandingen van roggen (in ton) per soort(groep) voor de periode 1967-1983 (boven) en 1998-2016 (onder). De gegevens voor 1979 en 1981 zijn onvolledig. (Gegevens afkomstig uit de WMR VISSTAT database). 


\section{Roggen aanlandingen Nederlandse schepen in studiegebied}

80

70

60

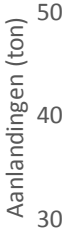

20

10

0

1967
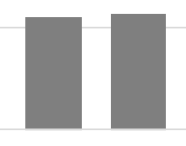

19691970

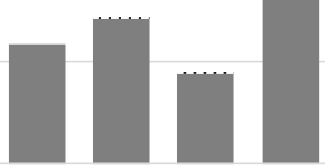

19711972

- Rogachtigen $\quad$ Vleet

Pijlstaartrog

Roggen aanlandingen Nederlandse schepen in studiegebied

8

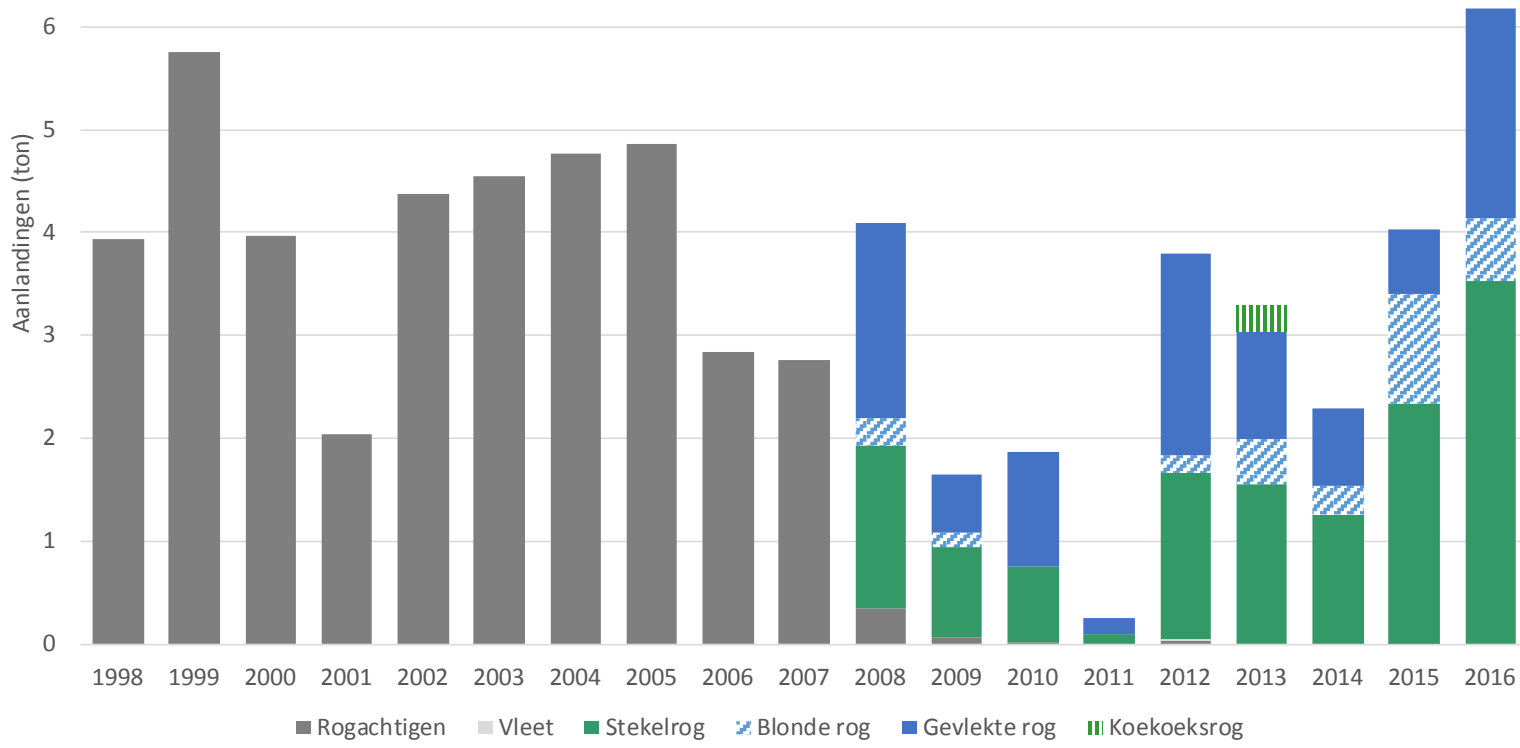

Figuur 9 Nederlandse aanlandingen van roggen (in ton) per soort(groep)* voor de periode 1967-1983 (boven) en 1998-2016 (onder) uit het studiegebied (d.w.z. ICES-kwadranten 31F3, 32F3, 31F4, 32F4). De gegevens voor 1979 en 1981 zijn onvolledig. (Gegevens afkomstig uit de WMR VISSTAT database). $*$ Let op: de y-assen van de twee figuren verschillen met een factor 10. 
70

60

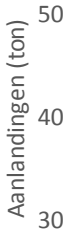

20

10

1967

19681969
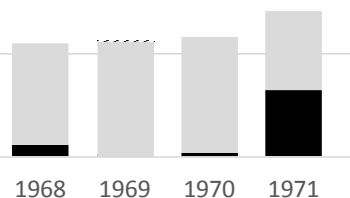

19711972

Roggen aanlandingen Nederlandse schepen in studiegebied

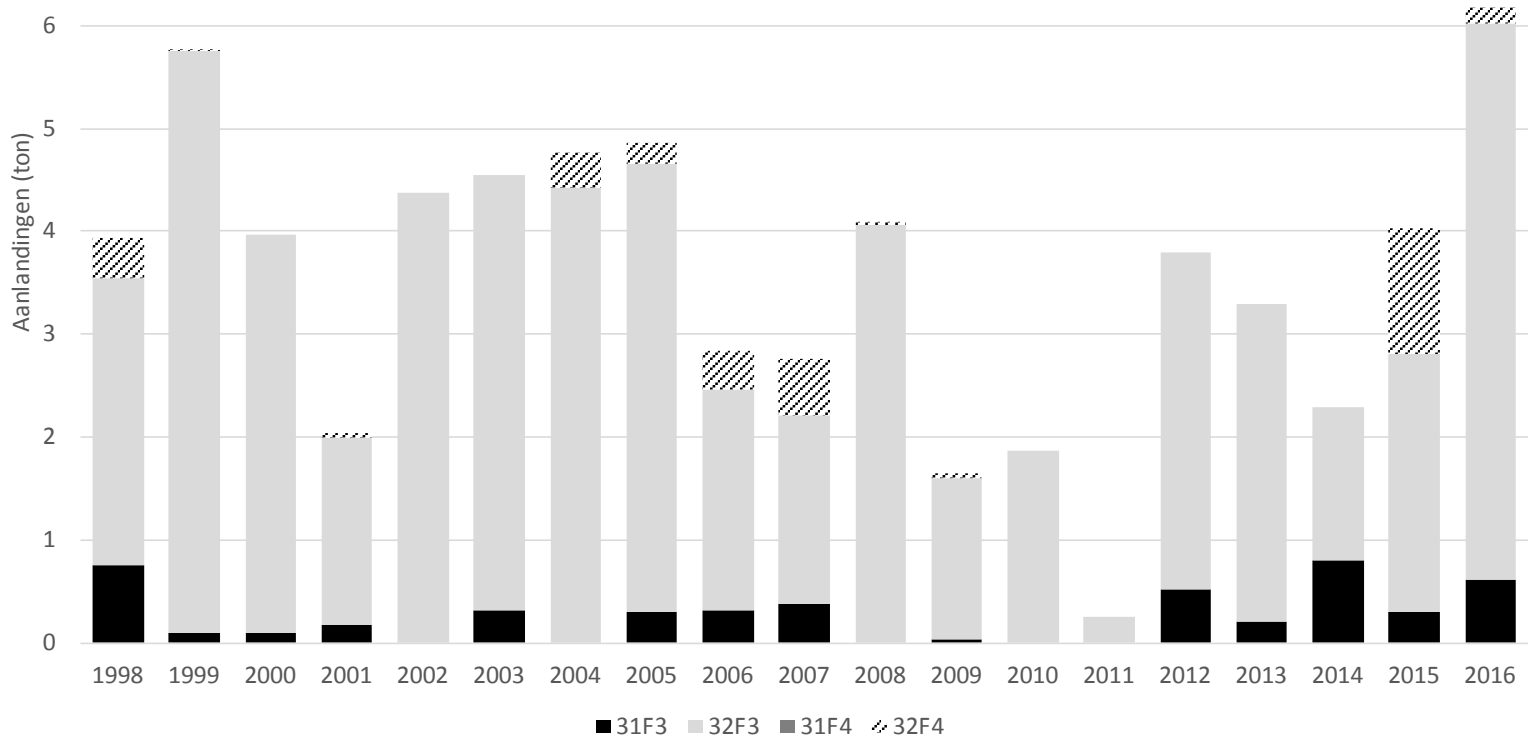

Figuur $10 \quad$ Nederlandse aanlandingen van roggen (in ton) per ICES kwadrant* binnen het studiegebied voor de periode 1967-1983 (boven) en 1998-2016 (onder). De gegevens voor 1979 en 1981 zijn onvolledig. (Gegevens afkomstig uit de WMR VISSTAT database). * Let op: de y-assen van de twee figuren verschillen met een factor 10 . 
Tabel $1 \quad$ Relatieve bijdrage (uitgedrukt in proportie) per soort(groep) en alle roggensoorten samen van de Nederlandse aanlandingen in het studiegebied t.o.v. totale Nederlandse aanlandingen voor de periode 1967-1983.

* Deze proportie is gebaseerd op de gegevens van rogachtigen, vleet en pijlstaartrog.

\begin{tabular}{|c|c|c|c|c|}
\hline & Rogachtigen & Vleet & Pijlstaartrog & Alle roggen soorten* \\
\hline 1967 & 0.062 & 0.006 & & 0.046 \\
\hline 1968 & 0.163 & & & 0.128 \\
\hline 1969 & 0.130 & & & 0.113 \\
\hline 1970 & 0.138 & 0.002 & & 0.127 \\
\hline 1971 & 0.152 & $<0.001$ & 1 & 0.135 \\
\hline 1972 & 0.071 & 0.002 & 0.164 & 0.065 \\
\hline 1973 & 0.128 & & 0.863 & 0.120 \\
\hline 1974 & 0.094 & & & 0.091 \\
\hline 1975 & 0.065 & $<0.001$ & & 0.063 \\
\hline 1976 & 0.034 & & & 0.033 \\
\hline 1977 & 0.029 & & & 0.029 \\
\hline 1978 & 0.004 & & & 0.004 \\
\hline 1979 & 0.004 & & & 0.004 \\
\hline 1980 & 0.001 & & & 0.001 \\
\hline 1981 & 0.002 & & 1 & 0.003 \\
\hline 1982 & 0.002 & & & 0.002 \\
\hline 1983 & 0.129 & & & 0.129 \\
\hline
\end{tabular}

Tabel 2 Relatieve bijdrage (uitgedrukt in proportie) per soort(groep) en alle roggensoorten samen van de Nederlandse aanlandingen in het studiegebied t.o.v. totale Nederlandse aanlandingen voor de periode 1998-2016.

* Deze proportie is gebaseerd op de gegevens van rogachtigen, vleet, stekelrog, blonde rog, gevlekte rog en koekoeksrog.

\begin{tabular}{|c|c|c|c|c|c|c|c|}
\hline & Rogachtigen & Vleet & Stekelrog & Blonde rog & Gevlekte rog & Koekoeksrog & Alle roggen soorten* \\
\hline 1998 & 0.006 & & & & & & 0.006 \\
\hline 1999 & 0.014 & & & & & & 0.014 \\
\hline 2000 & 0.007 & & & & & & 0.007 \\
\hline 2001 & 0.003 & & & & & & 0.003 \\
\hline 2002 & 0.006 & & & & & & 0.006 \\
\hline 2003 & 0.007 & & & & & & 0.007 \\
\hline 2004 & 0.009 & & & & & & 0.009 \\
\hline 2005 & 0.009 & & & & & & 0.009 \\
\hline 2006 & 0.004 & & & & & & 0.004 \\
\hline 2007 & 0.003 & & & & & & 0.003 \\
\hline 2008 & 0.005 & & 0.008 & 0.015 & 0.008 & & 0.008 \\
\hline 2009 & 0.026 & & 0.005 & 0.018 & 0.003 & & 0.004 \\
\hline 2010 & 0.004 & & 0.004 & & 0.006 & & 0.005 \\
\hline 2011 & & & 0.001 & & 0.001 & & 0.001 \\
\hline 2012 & 0.003 & 0.005 & 0.008 & 0.003 & 0.009 & & 0.007 \\
\hline 2013 & & & 0.010 & 0.009 & 0.008 & $0.057 \#$ & 0.010 \\
\hline 2014 & & & 0.008 & 0.010 & 0.003 & & 0.006 \\
\hline 2015 & 0.008 & & 0.012 & 0.009 & 0.004 & & 0.009 \\
\hline 2016 & & & 0.018 & 0.021 & 0.021 & & 0.019 \\
\hline
\end{tabular}

\# Koekoeksrog komt niet voor in Oosterschelde en Voordelta, want is een soort die alleen veel noordelijker voorkomt. Zie de Fish Atlas (Heessen et al., 2015). Dit is dus waarschijnlijk een vergissing bij de determinatie (Henk Heessen, pers. meded., 13 juni 2017). 
Gemiddelde LpUE roggen voor Nederlandse vloot met sleepnetten en zegen
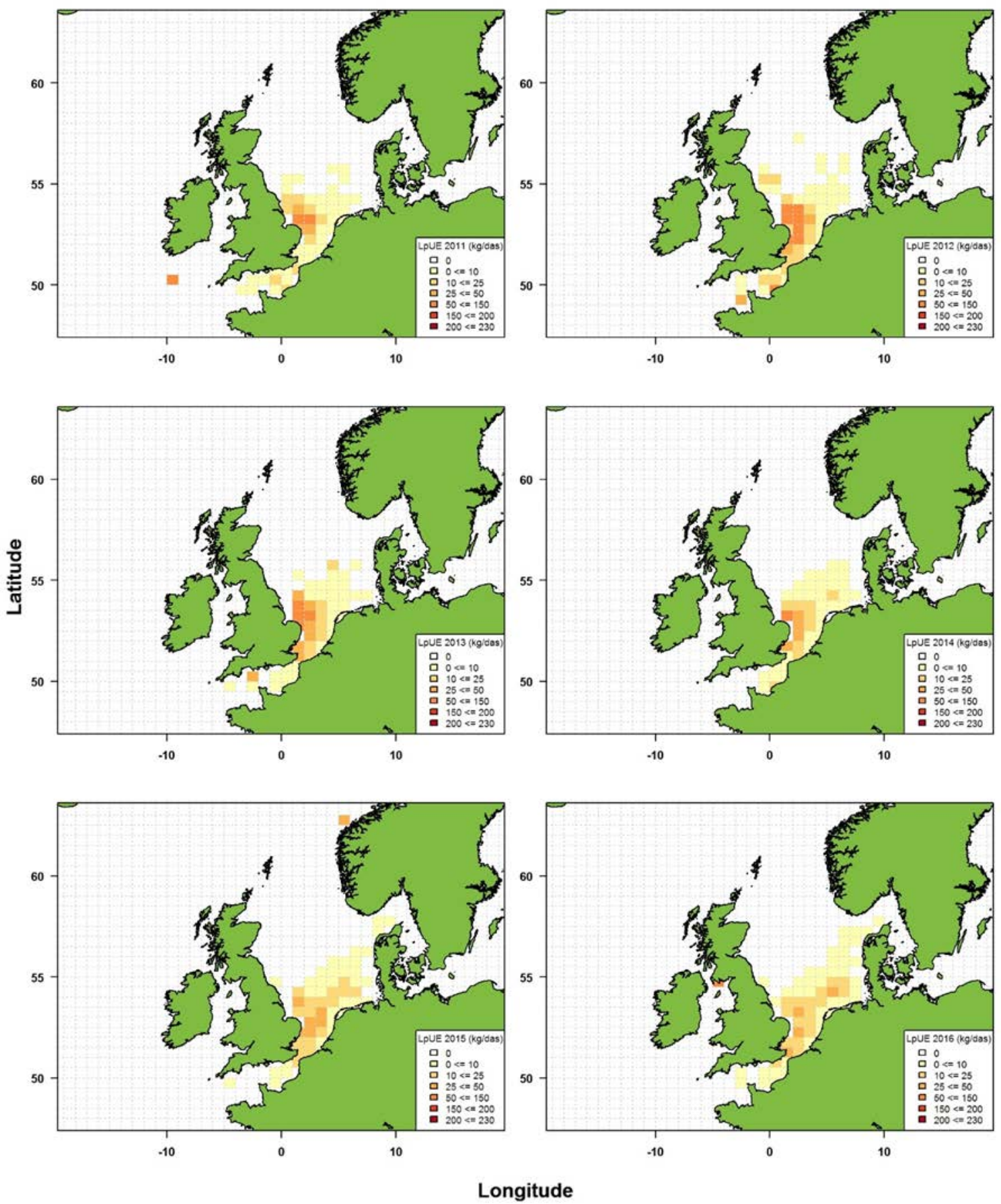

Figuur 11 Ruimtelijk gemiddeld aanlandingssucces roggen (uitgedrukt in LpUE - kg per dagen op zee) per jaar voor de Nederlandse sleepnetten- en zegenvisserij voor de periode 2011-2016. (Gegevens afkomstig uit de WMR VISSTAT database). 


\subsection{Demersale surveys}

In de Nederlandse kustwateren worden diverse surveys met onderzoeksvaartuigen uitgevoerd waarin ook stekelroggen kunnen worden aangetroffen. In deze rapportage wordt onderscheid gemaakt tussen de Voordelta en de Oosterschelde, want de Voordelta wordt bemonsterd in 4 surveys en de Oosterschelde in één survey. De kenmerken van de 4 soorten surveys zijn schematisch opgenomen in Bijlage 2.

\subsubsection{Voordelta}

Alle data uit de WMR Frisbe database zijn doorzocht op het voorkomen van roggen. In de Frisbe database staan gegevens die door WMR zijn verzameld. Dat zijn gegevens van vissurveys en commerciële bemonsteringen. Vervolgens is er een selectie gemaakt op basis van het Natura 2000gebied de Voordelta en zijn de consistent uitgevoerde demersale surveys geselecteerd (DFS, IBTS, BTS, MVII). In totaal zijn er sinds 19701621 vistrekken geregistreerd in de Voordelta. Een overzicht van die vistrekken is te vinden in Bijlage 3. Hierin zijn echter maar 10 stekelroggen gevangen. Geen enkele andere roggensoort is in het gebied de Voordelta door een van de surveys gevangen. Al deze stekelroggen zijn gevangen in 2 verschillende jaren $(2007,2013)$ tijdens surveys uitgevoerd in het kader van de Maasvlakte II (MVII). In beide kwartalen ( $2^{e}$ en $3^{e}$ ) zijn stekelroggen gevangen (Tabel 3). In onderstaande kaartje staan ook nog waarnemingen van andere programma's zoals het discardprogramma van de commerciële boomkor.

Tabel 3 Aantal stekelroggen dat is aangetroffen in 4 demersale surveys (DFS, IBTS, BTS, MVII)

\begin{tabular}{|l|c|c|c|c|c|}
\hline Survey & 2007 & 2007 & 2013 & 2013 & $\begin{array}{c}\text { Totaal periode } \\
1970-2017\end{array}$ \\
\hline DFS & 2 2e kwartaal & 3e kwartaal & 2 2e kwartaal & 3e kwartaal & \\
\hline IBTS & & & & & 0 \\
\hline BTS & & & & & 0 \\
\hline MVII & & & & & 0 \\
\hline
\end{tabular}




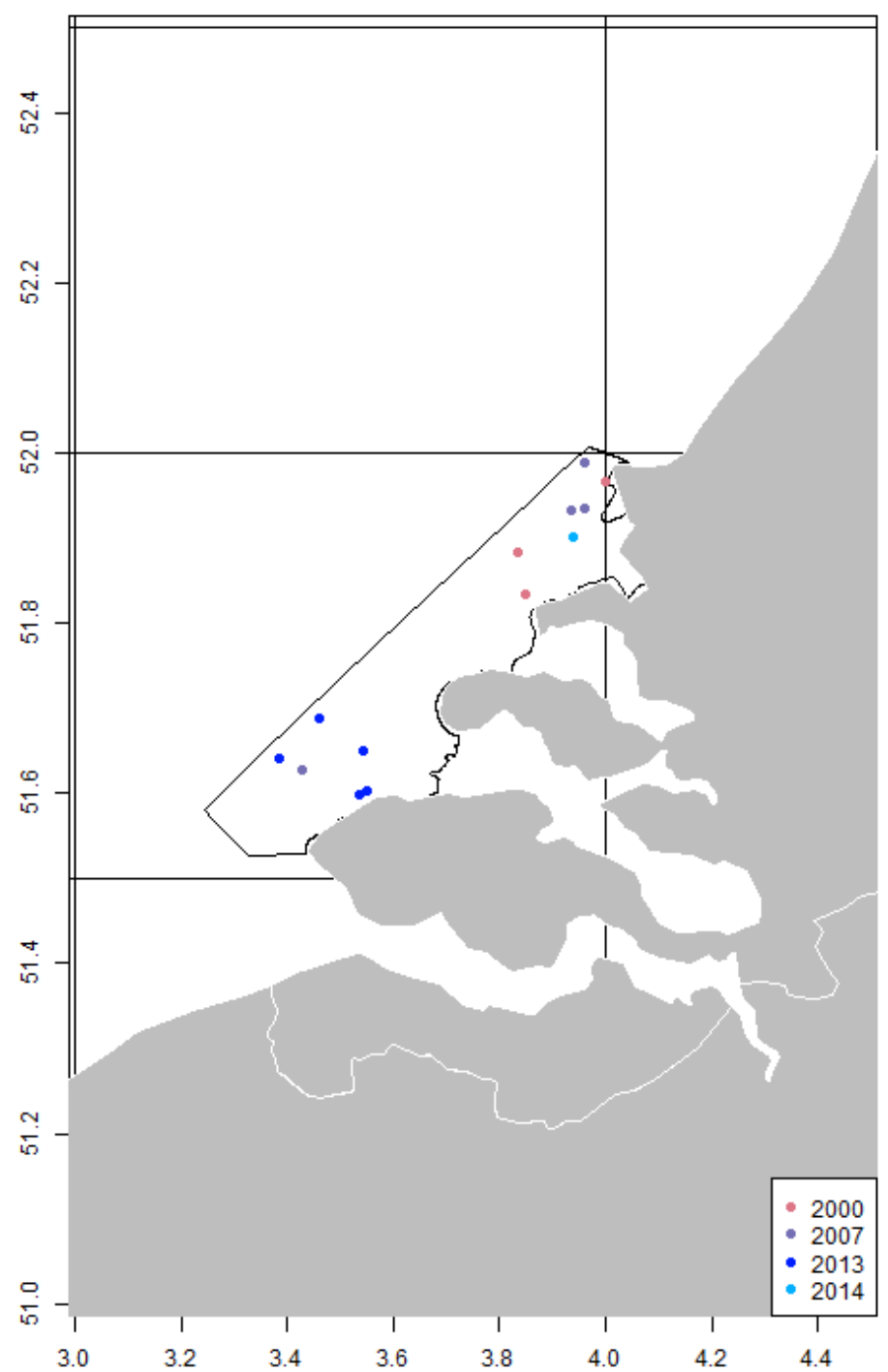

Figuur 12 Locaties waar stekelroggen in de Voordelta zijn gevangen in demersale vissurveys (DFS, IBTS, BTS, MVII) in de periode $1970 \mathrm{t} / \mathrm{m} 1^{\mathrm{e}}$ kwartaal 2017 en andere programma's (discard programma van de commerciële boomkor (DISBT), N2000CR programma). Vangsten: 2000 in DISBT; 2007 en 2013 in MVII; 2014 in N2000CR. Geen vangsten gedaan in DFS, IBTS, BTS.

\subsubsection{Oosterschelde}

De Oosterschelde is bemonsterd sinds 1970 als onderdeel van de DFS. In 1970 is 1 maal een stekelrog geregistreerd. In geen van de jaren erna is de stekelrog gevangen. In 1981 is er een niet geïdentificeerde rog gevangen. In 1983, 1999, en 2009 is er 1 pijlstaartrog gevangen. In 2013 zijn er 3 pijlstaartroggen gevangen.

Hierbij kan worden opgemerkt dat er voor de Oosterschelde slechts een beperkte dekking is met surveys. Het vistuig dat is gebruikt voor DFS is niet zo effectief voor het vangen van (sub)adulte stekelroggen. Hierop wordt in de discussie (sectie 6.1) verder ingegaan. 


\section{$4 \quad$ Habitateisen van de stekelrog}

Er zijn een tiental publicaties geselecteerd die goed kunnen worden gebruikt voor de huidige studie naar de habitatgeschiktheid van gebieden voor de stekelrog. Deze publicaties worden hieronder besproken. Hierbij wordt onderscheid gemaakt tussen abiotische en biotische factoren die worden beschreven in verschillende paragrafen. De studies hebben betrekking op verschillende gebieden. De focus lag op de zuidelijke Noordzee vanwege de vergelijkbaarheid met de Oosterschelde en Voordelta. Echter daar het aantal studies beperkt bleek te zijn, zijn ook studies over andere gebieden geselecteerd, zoals andere delen van de Noordzee, het Kanaal, Keltische Zee, lerse Zee, Middellandse Zee. In de meeste studies is de habitatgeschiktheid gemodelleerd met behulp van correlaties tussen de presentie van stekelroggen en de omgevingsfactoren.

\subsection{Abiotische factoren}

Martin et al. (2012) gebruikten Generalised Linear Models (GMLS), gecombineerd met GIS om de habitats van stekelrog in het Kanaal te voorspellen. Dit was gebaseerd op jaarlijkse visserijonafhankelijke bottom trawl surveys gedurende een periode van 21 jaar. Habitat modelberekeningen leverden gemiddelde dichtheidsniveau's voor de stekelrog. De belangrijkste ( $1^{\mathrm{e}}$ orde) voorspellers voor stekelroghabitats in het Kanaal waren diepte, bodemschuifspanning en saliniteit, gevolgd door $2^{\mathrm{e}}$ orde voorspellers bodemsedimenttype en watertemperatuur. Een toelichting op bodemschuifspanning wordt gegeven in paragraaf 5.1. Stekelrog vertoont in het Kanaal een breed habitatgebruik met een brede range voor de waarden van bovengenoemde abiotische factoren. Dit habitatgebruik is wel sterk leeftijdsafhankelijk, waarbij Martin et al. (2012) onderscheid maken tussen enerzijds pasgeborenen en jongen en anderzijds subadult en adult. De pasgeborenen en jongen (0-1 jaar groep) prefereren ondiepe kustwateren, beschermd tegen getijdestromingen en met zachter sediment (slib en zand). De subadulten en adulten ( $2+$ groep) prefereren harde sedimenten (gravel en kiezels), wat dieper water met matige tot sterke getijdenstroming. Dit is consistent met eerdere studies in dit gebied en in andere gebieden.

J onge stekelroggen zijn waarschijnlijk beperkt in hun zwemcapaciteiten en daardoor extra kwetsbaar voor predatoren in ongeschikte habitats. Ondiepe kustwateren zijn wel gunstig want deze bieden bescherming bieden tegen predatie, overvloedig voedselaanbod en warmer water waarmee de groei wordt versneld. Martin et al. (2012) concluderen dat voor de stekelrog meer kennis nodig is voordat ruimtelijk management op betrouwbare wijze kan worden toegepast voor deze soort.

Maxwell et al. (2009) benutten survey data van een 14 jarige periode om met regressiemodellen en geostatistische tools een verspreidingskaart voor stekelrog in drie hydrografische regio's rond de UK (Engelse deel van het Kanaal, delen van Ierse Zee en Keltische zee) te construeren. Zij betrokken hierbij de omgevingsvariabelen: diepte, bodemtemperatuur, zeebodemschuifspanning en sediment type, als voorspellers. Het voorkomen van de stekelrog was positief gerelateerd aan ondiepe gebieden, een zeebodemschuifspanning tussen 0 en $1.5 \mathrm{~N} / \mathrm{m}^{2}$, en de aanwezigheid van zandig sediment. De voorspelde aanwezigheid was in goede overeenstemming met de survey waarnemingen.

De stekelrogmodellen waren vergelijkbaar voor het Engelse Kanaal en de Keltische Zee met de conclusie dat diepte, zeebodemschuifspanning, temperatuur voorspellers zijn van de verspreiding van stekelroggen. De I erse Zee toonde een verschil met het Engelse Kanaal en de Keltische Zee, want voor de lerse Zee is temperatuur geen voorspeller, maar sediment type wel een voorspeller van de verspreiding van stekelroggen. De auteurs vermelden dat dit laat zien dat men voorzichtig moet zijn met de modellering van de verdeling van de soort over een groter geografisch gebied en de extrapolatie naar andere gebieden. 
Er zijn overeenkomsten en verschillen tussen de conclusies van Martin et al. (2012) en Maxwell et al. (2009) m.b.t. de stekelrog in het Kanaal. Beide concluderen dat diepte en zeebodemschuifspanning zeer belangrijke voorspellers zijn. Martin et al. (2012) noemen daarbij nog saliniteit, terwijl Maxwell et al. (2009) temperatuur noemen. De verschillen in de opzet van de analyses kunnen dit verschil mogelijk verklaren. Martin et al. (2012) hebben namelijk het hele gebied van het Kanaal bestudeerd, terwij I Maxwell et al. (2009) alleen het Engelse deel van het Kanaal hebben bestudeerd. Daarnaast hebben Martin et al. (2012) in tegenstelling tot Maxwell et al. (2009) onderscheid gemaakt tussen twee ontwikkelingsstadia van de stekelrog.

Sguotti et al. (2016) vonden met een habitatmodel een nauwe associatie van de stekelrog met warmer zeewater (jaargemiddelde temperatuur in bovenste deel van de range van 9.5 tot $12{ }^{\circ} \mathrm{C}$ ), waarbij ondieper water (hoofdzakelijk 5-40 m), en hard, grof, gemengd en onbekende sedimenten werden geprefereerd. De relatie tussen bodemschuifspanning en saliniteit en het voorkomen van de stekelrog is niet door Sguotti et al. (2016) onderzocht.

Hunter et al. (2005) onderzochten de ruimtelijke en temporele verspreiding van in het Theems estuarium gevangen stekelroggen door deze te merken met data storage tags (DSTs) of met plastic tags. Ongeveer de helft van de tags werd geretourneerd. Bijna alle teruggevangen stekelroggen waren afkomstig uit het Theems estuarium. De gemiddelde dagtemperatuur en zeebodemdiepte werden geregistreerd. Beide parameters vertoonden een jaarlijkse cyclus. De maximum en minimum temperaturen waren respectievelijk $22.2^{\circ} \mathrm{C}$ en $4.9{ }^{\circ} \mathrm{C}$, terwijl de diepte varieerde tussen 60 en $1 \mathrm{~m}$. De roggen bevonden zich gedurende herfst en winter in dieper water van 20-35m en ook > $35 \mathrm{~m}$. daarna migreerden ze in het voorjaar naar ondiep water $(<20 \mathrm{~m}$ diepte) en gedurende de reproductieperiode (maart - oktober) bevonden de meeste roggen zich in water ondieper dan $10 \mathrm{~m}$.

De aanwezigheid van stekelroggen in de ondiepe estuaria en de Waddenzee in de zomermaanden wijst op de voorkeur voor warm water en hun tolerantie voor estuariën water met een laag zoutgehalte. De verspreiding van roggen wordt niet duidelijk beïnvloed door waterstroming (Walker, 1996).

Fock (2014) analyseerde de gegevens van de verspreiding van stekelroggen in de Duitse Bocht gedurende 3 perioden tussen 1902 en 2009. Hij concludeerde dat in de periode 1902-1908, toen de visserijdruk laag was, stekelroggen voorkwamen in habitats geassocieerd met voedselgebieden. $\mathrm{Er}$ was toen een negatief verband tussen stekelrogverspreiding en gravel- en slibgronden. In de recentere perioden (bijvoorbeeld 1930-1932) was de visserijdruk groot en werd minder riskant habitat door stekelroggen bezet, dat zwakker geassocieerd was met foerageergebieden, zonder verband met sedimenttype. Daarna werd de visserijdruk zo groot dat de stekelrog uiteindelijk verdween (vanaf 1991). Dit illustreert dat habitatgebruik door de stekelrog niet de voorkeur van de stekelrog hoeft te weerspiegelen in aanwezigheid van een grote visserijdruk.

Humphries et al. (2016) onderzochten de geprefereerde diepterange van 43 stekelroggen in het Kanaal met behulp met electronic data storage tags. Er was een duidelijke geprefereerde relatief nauwe diepterange tussen 5 en $20 \mathrm{~m}$. De meeste exemplaren hielden zich op rond $10 \mathrm{~m}$ diepte en de gemiddelde diepte was $18 \mathrm{~m}$. Er was enig bewijs voor een verschuiving met seizoen met een iets grotere diepte gedurende de zomer. De diepte tijdens een etmaal varieerde relatief weinig en was iets dieper tijdens de dag en iets ondieper tijdens de nacht. De watertemperatuur waar de getagde stekelroggen zich ophielden varieert ca. $7{ }^{\circ} \mathrm{C}$ gedurende het jaar, met de hoogste temperatuur van $15.5^{\circ} \mathrm{C}$ eind zomer en de laagste temperatuur van $8.5^{\circ} \mathrm{C}$ eind winter. Het studiegebied betreft goed gemengde wateren die geen afname van temperatuur met diepte hebben zoals op veel andere locaties geldt. Er is geen relatie tussen diepte en temperatuur gevonden. Voor de gemerkte dieren lijkt daarom temperatuur geen sturende factor en ook geen gevolg te zijn van habitatvoorkeur. De diepte is wel een sturende factor voor de stekelrog in dit gebied.

De informatie over roggen is data arm in vergelijking met commercieel geëxploiteerde beenvissen. Dit hindert het inzicht in de abundantie verspreiding en de relatie hiervan met de omgevingsfactoren voor zowel adulte als juveniele levensstadia. Dedman et al. (2015) hebben een methode toegepast die geschikt is voor data arme soorten zoals roggen in de Ierse Zee. Dit is de delta log-normal boosted 
regression trees. Hieruit bleek dat de verspreiding van de stekelrog werd gestuurd door een voorkeur voor zand en grovere substraten, hogere saliniteiten, hogere temperaturen, grotere stroomsnelheden. Vergelijking tussen abundantieverspreiding en locaties van commerciële visserij indiceerde dat de belangrijkste hotspots van roggen zich buiten de belangrijkste commerciële visserijgebieden bevinden.

In de centrale Middellandse Zee bleken 5 omgevingsfactoren de habitatgeschiktheid voor stekelroggen te sturen, namelijk diepte, watertemperatuur, saliniteit, sediment type en ruwheid van de zeebodem. Stekelroggen prefereren de ondiepe wateren van kustgebieden en bepaalde banken, alsmede zeebodem met zachte substraten Lauria et al. (2015).

Juveniele stekelroggen, met een leeftijd tussen 13 en 21 maanden en een vin tot vinbreedte tussen 15 en $32 \mathrm{~cm}$, zijn door Greenway et al. (2016) getest in aquaria in hun keuze en gedrag met betrekking tot type en kleur van substraat en gebruik van schuilplaats. Deze dieren bleken zacht geel zand te prefereren boven grof gravel. Kunstmatige en natuurlijke schuilplaatsen werden niet gebruikt.

Een compilatie van de milieuomgevingsfactoren en de bijbehorende waarden uit de studies die hierboven zijn beschreven studies is gemaakt in Tabel 4.

Tabel $4 \quad$ Waarden voor abiotische milieufactoren als sturende factoren in studies naar habitatgeschiktheid van stekelroggen in diverse gebieden in en nabij de zuidelijke Noordzee

\begin{tabular}{|c|c|c|c|c|}
\hline $\begin{array}{l}\text { Milieu- } \\
\text { factor }\end{array}$ & Gebied & $\begin{array}{l}\text { Waarden in } \\
\text { onderzochte } \\
\text { gebied }\end{array}$ & $\begin{array}{l}\text { Waarden door stekelrog } \\
\text { geprefereerd }\end{array}$ & Referentie \\
\hline Diepte & $\begin{array}{l}\text { Engels Kanaal } \\
\text { (UK deel) }\end{array}$ & $0-82 \mathrm{~m}$ & Ondiepe gebieden* & $\begin{array}{l}\text { Maxwell et al. } \\
(2009)\end{array}$ \\
\hline Diepte & lerse Zee & $8-134 m$ & Ondiepe gebieden & $\begin{array}{l}\text { Maxwell et al. } \\
(2009)\end{array}$ \\
\hline Diepte & $\begin{array}{l}\text { Keltische Zee } \\
\text { (UK deel) }\end{array}$ & $8-113 m$ & Ondiepe gebieden & $\begin{array}{l}\text { Maxwell et al. } \\
(2009)\end{array}$ \\
\hline Diepte ${ }^{1}$ & Engels Kanaal & $0-82 \mathrm{~m}$ & $\begin{array}{l}\text { Brede range en leeftijdsafhankelijk: } \\
\text { ondiep (juv.) tot dieper ( } 82 \mathrm{~m} \text { ) (ad.) }\end{array}$ & $\begin{array}{l}\text { Martin et al. } \\
(2012)\end{array}$ \\
\hline Diepte & Noordzee & $0-120 \mathrm{~m}$ & Ondiep (voornamelijk 5-40 m) & $\begin{array}{l}\text { Sguotti et al. } \\
(2016)\end{array}$ \\
\hline Diepte & $\begin{array}{l}\text { Middellandse Zee } \\
\text { (centraal) }\end{array}$ & $1-1793$ & Ondiep & $\begin{array}{l}\text { Lauria et al. } \\
(2015)\end{array}$ \\
\hline Diepte & lerse Zee & Niet gerapporteerd & & $\begin{array}{l}\text { Dedman et al. } \\
(2015)\end{array}$ \\
\hline Diepte & $\begin{array}{l}\text { Engels Kanaal } \\
\text { (west) }\end{array}$ & $0-80 m$ & $\begin{array}{l}\text { 5-20 m met gemiddelde van } 18 \mathrm{~m} \\
\text { en max. abundantie rond } 10 \mathrm{~m}\end{array}$ & $\begin{array}{l}\text { Humphries et al } \\
(2016)\end{array}$ \\
\hline Diepte & $\begin{array}{l}\text { Zuidelijke } \\
\text { Noordzee }\end{array}$ & Niet gerapporteerd & $\begin{array}{l}20-35 \mathrm{~m} \text { gedurende herfst en } \\
\text { winter; }<20 \text { m gedurende voorjaar } \\
\text { en zomer }\end{array}$ & $\begin{array}{l}\text { Hunter et al. } \\
(2005)\end{array}$ \\
\hline Diepte \# & Duitse Bocht & Niet gerapporteerd & Ondiep & Fock (2014) \\
\hline $\begin{array}{l}\text { Bodemschuifs } \\
\text { panning }\end{array}$ & $\begin{array}{l}\text { Engels Kanaal } \\
\text { (UK deel) }\end{array}$ & $0.1-3.0 \mathrm{~N} / \mathrm{m} 2$ & $\begin{array}{l}\text { Bodemschuifspanning tussen } 0 \text { en } \\
1.5 \mathrm{~N} / \mathrm{m} 2\end{array}$ & $\begin{array}{l}\text { Maxwell et al. } \\
(2009)\end{array}$ \\
\hline $\begin{array}{l}\text { Bodemschuifs } \\
\text { panning }\end{array}$ & slerse Zee & $0.02-3.0 \mathrm{~N} / \mathrm{m} 2$ & $\begin{array}{l}\text { Bodemschuifspanning tussen } 0 \text { en } \\
1.5 \mathrm{~N} / \mathrm{m} 2\end{array}$ & $\begin{array}{l}\text { Maxwell et al. } \\
(2009)\end{array}$ \\
\hline $\begin{array}{l}\text { Bodemschuifs } \\
\text { panning }\end{array}$ & $\begin{array}{l}\text { Keltische Zee } \\
\text { (UK deel) }\end{array}$ & $0.01-3.0 \mathrm{~N} / \mathrm{m} 2$ & $\begin{array}{l}\text { Bodemschuifspanning tussen } 0 \text { en } \\
1.5 \mathrm{~N} / \mathrm{m} 2\end{array}$ & $\begin{array}{l}\text { Maxwell et al. } \\
(2009)\end{array}$ \\
\hline $\begin{array}{l}\text { Bodemschuifs } \\
\text { panning }{ }^{1}\end{array}$ & Engels Kanaal & $0-3 \mathrm{~N} / \mathrm{m} 2$ & $\begin{array}{l}\text { Brede range en leeftijdsafhankelijk } \\
\text { van zwak (juv.) tot intermediair tot } \\
\text { sterke getijdestromingen (adults) }\end{array}$ & $\begin{array}{l}\text { Martin et al. } \\
(2012)\end{array}$ \\
\hline Saliniteit ${ }^{1}$ & Engels Kanaal & 32.4-34.9 ppt & $\begin{array}{l}\text { Vrij breed (iets lagere saliniteit voor } \\
\text { juvenielen) }\end{array}$ & $\begin{array}{l}\text { Martin et al. } \\
(2012)\end{array}$ \\
\hline
\end{tabular}




\begin{tabular}{|c|c|c|c|c|}
\hline $\begin{array}{l}\text { Milieu- } \\
\text { factor }\end{array}$ & Gebied & $\begin{array}{l}\text { Waarden in } \\
\text { onderzochte } \\
\text { gebied }\end{array}$ & $\begin{array}{l}\text { Waarden door stekelrog } \\
\text { geprefereerd }\end{array}$ & Referentie \\
\hline Saliniteit & $\begin{array}{l}\text { Middellandse Zee } \\
\text { (centraal) }\end{array}$ & $37.9-38.1$ & Variabel (polynoom) & $\begin{array}{l}\text { Lauria et al. } \\
(2015)\end{array}$ \\
\hline Saliniteit & I erse Zee & $\begin{array}{l}\text { Niet gerapporteerd } \\
\text { (check suppl. data) }\end{array}$ & Hoge saliniteit (piek bij 34.5ppm) & $\begin{array}{l}\text { Dedman et al. } \\
(2015)\end{array}$ \\
\hline \begin{tabular}{|l|} 
Temperatuur \\
(bodem)
\end{tabular} & $\begin{array}{l}\text { Engels Kanaal } \\
\text { (UK deel) }\end{array}$ & $12.7-19.0{ }^{\circ} \mathrm{C}$ & Niet gerapporteerd & $\begin{array}{l}\text { Maxwell et al. } \\
(2009)\end{array}$ \\
\hline \begin{tabular}{|l|} 
Temperatuur \\
(bodem)
\end{tabular} & $\begin{array}{l}\text { Keltische Zee } \\
\text { (UK deel) }\end{array}$ & $9.8-17.9^{\circ} \mathrm{C}$ & Niet gerapporteerd & $\begin{array}{l}\text { Maxwell et al. } \\
(2009)\end{array}$ \\
\hline \begin{tabular}{|l|} 
Temperatuur \\
(zeewateropp \\
ervlakte) ${ }^{2}$
\end{tabular} & Engels Kanaal & $\begin{array}{l}\text { alleen gerapporteerd } \\
\text { voor oktober: } 14.7- \\
16.5^{\circ} \mathrm{C}\end{array}$ & Niet gerapporteerd & $\begin{array}{l}\text { Martin et al. } \\
(2012)\end{array}$ \\
\hline \begin{tabular}{l|} 
Temperatuur \\
(zeewateropp \\
ervlakte)
\end{tabular} & Noordzee & $9.5-12{ }^{\circ} \mathrm{C}$ & Warm & $\begin{array}{l}\text { Sguotti et al. } \\
(2016)\end{array}$ \\
\hline $\begin{array}{l}\text { Temperatuur } \\
\text { (zeewateropp } \\
\text { ervlakte) }\end{array}$ & $\begin{array}{l}\text { Middellandse Zee } \\
\text { (centraal) }\end{array}$ & $17.6-20.9^{\circ} \mathrm{C}$ & Warm & $\begin{array}{l}\text { Lauria et al. } \\
\text { (2015) }\end{array}$ \\
\hline $\begin{array}{l}\text { Temperatuur } \\
\text { (zeewater) }\end{array}$ & Ierse Zee & $\begin{array}{l}\text { Niet gerapporteerd } \\
\text { (check suppl. data) }\end{array}$ & Warm & $\begin{array}{l}\text { Dedman et al. } \\
(2015)\end{array}$ \\
\hline $\begin{array}{l}\text { Temperatuur } \\
\text { (zeewater) }\end{array}$ & $\begin{array}{l}\text { Zuidelijke } \\
\text { Noordzee }\end{array}$ & Niet gerapporteerd & $\begin{array}{l}\text { tussen } 6 \text { (einde winter) en } 18.5^{\circ} \mathrm{C} \\
\text { (einde zomer) }\end{array}$ & $\begin{array}{l}\text { Hunter et al. } \\
(2005)\end{array}$ \\
\hline \begin{tabular}{l|} 
Sediment \\
type
\end{tabular} & lerse Zee & $\begin{array}{l}\text { Slib }(11.5 \%), \text { zand } \\
(61.2 \%), \text { gravel } \\
(25.8 \%), \text { gemengd } \\
(1.5 \%)\end{array}$ & Zandig sediment & $\begin{array}{l}\text { Maxwell et al. } \\
(2009)\end{array}$ \\
\hline $\begin{array}{l}\text { Sediment } \\
\text { type }^{2}\end{array}$ & Engels Kanaal & $\begin{array}{l}\text { Slib, fijn zand, grof } \\
\text { zand, gravel, kiezels }\end{array}$ & $\begin{array}{l}\text { Brede range (slib, fijn zand, grof } \\
\text { zand, gravel, kiezels) en } \\
\text { leeftijdsafhankelijk van slib en } \\
\text { zandig (juv. stekelrog) tot gravel } \\
\text { and kiezels (ad. stekelrog) }\end{array}$ & $\begin{array}{l}\text { Martin et al. } \\
(2012)\end{array}$ \\
\hline $\begin{array}{l}\text { Sediment } \\
\text { type }\end{array}$ & Noordzee & $\begin{array}{l}\text { Slib tot zandig slib, } \\
\text { zand tot slibbig zand, } \\
\text { grof sediment, } \\
\text { gemengd sediment, } \\
\text { stenen of harde } \\
\text { substraten, onbekend } \\
\text { sediment }\end{array}$ & $\begin{array}{l}\text { Gemengd, onbekend }>\text { stenig, grof } \\
\text { zand }>\text { zand, slib }\end{array}$ & $\begin{array}{l}\text { Sguotti et al. } \\
(2016)\end{array}$ \\
\hline $\begin{array}{l}\text { Sediment } \\
\text { type }\end{array}$ & lerse Zee & $\begin{array}{l}\text { Niet gerapporteerd } \\
\text { (check suppl. data) }\end{array}$ & Zand en grovere substraten & $\begin{array}{l}\text { Dedman et al. } \\
(2015)\end{array}$ \\
\hline $\begin{array}{l}\text { Sediment } \\
\text { type } \#\end{array}$ & Duitse Bocht & $\begin{array}{l}\text { Slib, zand, slibbig } \\
\text { zand, en gravel }\end{array}$ & $\begin{array}{l}\text { Zand in afwezigheid van grote } \\
\text { bodemvisserijdruk }\end{array}$ & Fock (2014) \\
\hline $\begin{array}{l}\text { Tijdstrend } \\
\text { (decade) }\end{array}$ & Noordzee & $1900-2014$ & Afname & $\begin{array}{l}\text { Sguotti et al. } \\
(2016)\end{array}$ \\
\hline
\end{tabular}

$\mathrm{Er}$ is getracht uit Tabel 4 een algemene lijn te destilleren voor elke van belang zijnde omgevingsfactor. Dit blijkt voor 3 van de 5 factoren complex te zijn, vanwege de geconstateerde verschillen. Deze factoren zijn diepte, watertemperatuur en sediment type. 
Bijvoorbeeld in geval van het sedimenttype prefereren adulte stekelroggen in enkele gebieden, zoals I erse Zee (Maxwell et al., 2009) en de Middellandse Zee (Lauria et al., 2015), zachte substraten, vooral zand, terwijl dat in andere gebieden zoals de Noordzee (Sguotti et al., 2016) en het Kanaal (Martin et al., 2012) en de Keltische Zee grovere sedimenttypen zijn. Dit kan te maken hebben met een andere oorzaak, zoals effect van verdringing van stekelroggen naar moeilijker bevisbare gebieden die een grover sedimenttype hebben. Hiervoor heeft Fock (2014) aanwijzingen gevonden in zijn analyse. Dit is als zodanig beknopt vermeld in Tabel 4 en Tabel 5. Tabel 5 geeft een overzicht van de geprefereerde waarden van de belangrijkste - kwantificeerbare - factoren nadat er een harmonisatie op de resultaten van Tabel 4 is toegepast.

Tabel 5 Afgeleide waarden voor de door stekelroggen geprefereerde range van de abiotische milieufactoren die voorspellers zijn van stekelrog habitats

\begin{tabular}{|l|l|}
\hline Factoren & Waarden door stekelrog geprefereerd \\
\hline Diepte & $\begin{array}{l}\text { Brede range en leeftijdsafhankelijk: ondiep voor juvenielen en dieper (tot } 40 \mathrm{~m} \text { en } \\
\text { tot } 82 \mathrm{~m} \text { ) voor adulten. In Noordzee seizoensafhankelijk: dieper (20-35 } \mathrm{m} \text { ) } \\
\text { gedurende herfst en winter; ondieper (<20 m) gedurende voorjaar en zomer }\end{array}$ \\
\hline $\begin{array}{l}\text { Bodemschuifspanning } \\
\text { (stroming en golven) }\end{array}$ & $\begin{array}{l}\text { Brede range en leeftijdsafhankelijk van zwak (juv.) tot intermediair tot sterke } \\
\text { getijdestromingen (adulten) (Martin et al. 2012). Tussen } 0 \text { en } 1.5 \mathrm{~N} / \mathrm{m} 2 \text { (Maxwell et } \\
\text { al., 2009) }\end{array}$ \\
\hline Saliniteit & Vrij brede range inclusief 32.4-34.9 ppt \\
\hline Watertemperatuur & $\begin{array}{l}\text { Hogere temperatuur in de range 9.5-19 }{ }^{\circ} \text { C. Juvenielen prefereren hogere temp, dan } \\
\text { adulten. Anderzijds is temperatuur geen voorspeller volgens Humphries et al. } \\
\text { (2016) }\end{array}$ \\
\hline Sediment type & $\begin{array}{l}\text { Brede range (slib, fijn zand, grof zand, gravel, kiezels) en leeftijdsafhankelijk van } \\
\text { slib en zandig (juv.) tot gravel en kiezels (ad.) en afhankelijk van visserijdruk }\end{array}$ \\
\hline
\end{tabular}

\subsection{Biotische factoren}

Biotische factoren die van belang zijn voor de ontwikkeling van een stekelrogpopulatie zijn:

- Voedselaanbod

- Concurrentie

- Predatie

- Parasieten en ziekten

Voedsel en voedselaanbod

Stekelroggen tot $80 \mathrm{~cm}$ eten hoofdzakelijk kreeftachtigen. Grotere roggen verschuiven hun voedselvoorkeur van benthische naar semi-pelagische prooi, en van kreeftachtigen naar vis. De roggen zijn opportunistisch in hun voedselkeuze en kunnen overschakelen van het ene naar het andere voedseltype, afhankelijk van de abundantie per seizoen. Het is onwaarschijnlijk dat de verspreiding van de soort wordt beperkt door de beschikbaarheid van hun prooi (Walker, 1996; Heessen et al., 2015).

\section{Concurrentie}

De stekelrog heeft veel meer kreeftachtigen in het dieet (79\%) dan de kleinoogrog (Raja microocellata) die in het Kanaal dezelfde diepterange bewoont en meer vis in het dieet heeft. Dit voorkomt wellicht concurrentie tussen beide soorten (Humphries et al., 2016). Daarnaast speelt het verschil in afmetingen van potentieel concurrerende roggensoorten mogelijk een rol bij de verdeling van de benutting van voedselbronnen op een fijnere schaal (Humphries et al., 2016). 


\section{Predatie, parasieten en ziekten}

Over predatoren, parasieten en ziekten van juveniele en adulte stekelroggen en de invloed die dat kan hebben op de populatieomvang in habitats van stekelroggen is naar wij weten nauwelijks iets bekend. Het is aannemelijk dat stekelroggen in ondiep water beter beschermd zijn tegen roofvissen dan in diep water.

\section{Habitatveranderingen}

Sommige veranderingen in habitat, zoals verdwijnen van ondergedoken zeegras (Zostera marina) en oppervlaktestructuur van habitat, kunnen negatief doorwerken op de gevoelige vroege levensstadia, bijvoorbeeld door het verlies aan verankering van eikapsels en bescherming tegen predatoren op juvenielen, en veranderingen in bentisch voedselaanbod voor juvenielen (Walker, 1996).

\subsection{Conclusies}

Het voorkomen van stekelroggen is afhankelijk van hoe de vijf abiotische omgevingsfactoren, zoals aangeduid in Tabel 4 en Tabel 5, en de vier biotische omgevingsfactoren van invloed zijn. Verschillende variabelen werken interactief. De tolerantie en de voorkeur van de stekelrog voor deze factoren moet een venster opleveren waarbinnen het habitat geschikt geacht wordt voor de stekelrog. Voor de abiotische factoren is dit waarschijnlijk redelijk in kaart te brengen. Dat geldt echter niet voor de biotische factoren. Daarvoor kunnen met de huidige kennis nog geen tolerantiegrenzen worden gegeven. 


\section{$5 \quad$ Habitatgeschiktheid Oosterschelde en Voordelta voor de stekelrog}

In dit hoofdstuk wordt een eerste analyse gemaakt van de potentiele geschiktheid van de Oosterschelde en de Voordelta als habitat voor de stekelrog. Daarvoor wordt bestudeerd in hoeverre de door de stekelrog geprefereerde habitatkenmerken, zoals samengevat in Tabel 5, aanwezig zijn in de Oosterschelde en Voordelta. Uit de gegevens die zijn gepresenteerd in hoofdstuk 3 blijkt dat de stekelrog dermate sporadisch voorkomt in Oosterschelde en Voordelta dat daarom een habitatgeschiktheidsanalyse met regressiemodellen op basis van correlaties tussen aangetroffen stekelroggen en milieuvariabelen van Oosterschelde en Voordelta nu niet haalbaar is. Er kan wel een andere soort habitatgeschiktheidsanalyse worden gedaan en die is $\mathrm{m}$.b.v. rekenregels ( $k$ wantitatief of kwalitatief) voor de aan- en afwezigheid gekoppeld aan waarden voor elke milieuvariabele zoals die werd gevonden voor andere gebieden dan de Oosterschelde en Voordelta. Hierbij wordt aangenomen dat de gebieden onderling dermate vergelijkbaar zijn dat de extrapolatie naar Oosterschelde en Voordelta kan worden toegepast. Een dergelijke aanpak, maar dan kwantitatief, is uitgevoerd in habitatgeschiktheidsstudies voor Platte oesters in windparken op de Noordzee (Smaal et al., 2017) en vogels in de Oosterschelde (Henkens et al., 2012).

\subsection{Abiotische factoren}

In hoofdstuk 4 van dit rapport is geconcludeerd dat de belangrijkste abiotische milieufactoren als voorspellers voor habitat voor stekelrog zijn:

- Diepte

- Bodemschuifspanning

- Zoutgehalte

- Watertemperatuur

- Sedimenttype

We gaan er hierbij vanuit dat deze milieufactoren met de bijbehorende door stekelroggen geprefereerde waarden in andere gebieden dan de Oosterschelde en Voordelta ook het meest gunstig zullen zijn voor stekelroggen in Oosterschelde en Voordelta. Vervolgens wordt in dit hoofdstuk informatie verzameld over de waarden (ranges) voor de milieufactoren in de Oosterschelde en de Voordelta.

- Voor Oosterschelde en Voordelta apart wordt elke milieufactor gekarakteriseerd als gunstig, minder gunstig, ongunstig.

- De habitatgeschiktheid in een (deel)gebied wordt bepaald door het totaal van de milieufactoren in dat (deel) gebied. In het geval dat een factor ongunstig is en de andere factoren gunstig zijn, zal de habitatgeschiktheid ongunstig zijn. M.a.w. de zwakste schakel bepaalt sterk de habitatgeschiktheid.

- Voor Oosterschelde en Voordelta wordt een globale ruimtelijk analyse gemaakt van de verdeling van gunstige, minder gunstige en ongunstige deelgebieden en hun omvang.

- Hierbij moet worden bedacht dat sommige variabelen aan elkaar gecorreleerd zijn. Niet elke variabele die een correlatie lijkt te hebben met de presentie van een soort, hoeft mechanistisch gezien een relatie te hebben met de habitatgeschiktheid van die soort. Bijvoorbeeld grotere waterstroming en grover sediment zijn vaak met elkaar gecorreleerd. Het is mogelijk dat slechts 1 van deze variabelen de habitatgeschiktheid voor de stekelrog echt beïnvloedt.

Onderhavige analyse is een potentiele habitatgeschiktheidsanalyse. De roggen moeten de

Oosterschelde en Voordelta kunnen bereiken vanuit de gebieden bij de Engelse oostkust of het Kanaal 
om zich te kunnen vestigen (Jeroen Wijsman, WMR, pers. mededeling). De migratieroute, migratieafstand en de aanwezigheid van fysieke obstakels spelen mee. Daarnaast kan er een te grote mortaliteit optreden door bepaalde menselijke activiteiten in het gebied, bijvoorbeeld visserij, zandsuppleties, e.d..

In het restant van deze paragraaf wordt voor elke milieufactor een korte beschrijving gegeven, waarbij hierbij gebruikte kaarten en grafieken zijn opgenomen in bijlagen. Een overzicht van alle behandelde factoren en de daaraan verbonden conclusies is te vinden in Tabel 6 en Tabel 7. Hierbij is onderscheid gemaakt tussen de beide studiegebieden Oosterschelde en Voordelta en tussen twee levensstadiagroepen van de stekelrog: 0 en $1^{\mathrm{e}}$ jaars, $2^{\mathrm{e}}$ jaars en ouder.

\section{Diepte}

De Oosterschelde is door de getijdenwerking een zeer variabel gebied, ook wat de waterdiepte betreft. Een kaart van de waterdiepte is te vinden in Bijlage 6. De maximale waterdiepte is $65 \mathrm{~m}$, maar er komt ook een groot oppervlak aan ondiep water voor. Voor juveniele stekelroggen is een geringe waterdiepte gunstig, mits de watertemperatuur daardoor niet extreem warm of koud kan worden (zie hieronder bij watertemperatuur). (Sub)adulte stekelroggen prefereren dieper water dan de juvenielen. Dit diepere water is ook veel te vinden in de Oosterschelde. Ondiep water is geschikt voor adulte stekelroggen wanneer ze zich voort willen planten en die gebieden komen in de Oosterschelde ook voor. Er kan dus worden geconcludeerd dat waterdiepte in de Oosterschelde geen beperkende factor is voor juveniele en adulte stekelroggen.

De Voordelta vertoont veel variatie in diepte (zie Bijlage 4 en Bijlage 7). Voor juveniele stekelroggen is de waterdiepte van de Voordelta geschikt. Voor subadulte en adulte stekelroggen zijn de meest ondiepe delen van de Voordelta (tot ca. $5 \mathrm{~m}$ ) minder gunstig, maar die vormen een relatief klein oppervlak van de Voordelta.

\section{Bodemschuifspanning}

Bodemschuifspanning kan worden gebruikt als een maat voor lokale bodemdynamiek.

Bodemschuifspanning is de kracht die bewegend water op de bodem uitoefent. Het is het resultaat van zowel stroming als van golven. In diep water dringen golven niet door tot op de bodem, in ondiep water is de kracht van golfwerking meestal dominant. De bodemschuifspanning bepaalt of deeltjes (bv. slib, zand of oesterlarven) opgewerveld worden of bezinken. Er zijn geen directe meetgegevens van bodemschuifspanning beschikbaar. Dit soort gegevens is alleen te verkrijgen uit modellen. De bodemschuifspanning is een functie van bodemruwheid en stroomsnelheid. De aanwezigheid van structuren (zoals epifauna, biogene riffen, lege schelpen) kan de bodemruwheid beïnvloeden. De waterbeweging door getij en golven is het sturende proces achter substraatdynamiek. Het substraat is meer of minder bewegelijk, afhankelijk van sediment, stroomsnelheid en aangevoerde golfenergie. De aanwezigheid van een lage bodemschuifspanning is van belang voor eikapsels en juveniele stekelroggen.

Er zijn geen studies gevonden waarin de bodemschuifspanning van de Oosterschelde is bepaald. Er is wel informatie over de stroomsnelheden in de Oosterschelde (zie Bijlage 10) en over de dynamiek voor de verschillende ecotopen in de Oosterschelde, in de vorm van een ecotopenkaart (zie Bijlage 15). Hier wordt $0.8 \mathrm{~m} / \mathrm{s}$ als grens gebruikt tussen laag en hoogdynamisch in het sublittoraal. De ecotopenkaart is een statische weergave van een dynamisch systeem en geeft een globaal overzicht van begrenzing van aanwezige ecotopen. In werkelijkheid verschuiven deze grenzen continu door de dynamiek in een systeem. In de Oosterschelde komen hoogdynamische (sub)litorale en laagdynamische (sub) litorale ecotopen voor. Het grootste deel van de ecotopen in de Oosterschelde zijn sublittorale ecotopen; Sublittoraal hoog dynamisch, Geulen laag dynamisch, Ondiep laag dynamisch en Middel littoraal laag dynamisch. De verhoudingen waarin deze ecotopen voorkomen variëren echter per bekken. De hoogdynamische sublitorale gebieden van de ecotopenkaart (Bijlage 15) en de gebieden met een hoge stroomsnelheid (Bijlage 10) hebben waarschijnlijk een grotere bodenschuifspanning, maar of die waarden bereikt worden die dermate hoog zijn dat die ongunstig worden voor eikapsels en juveniele stekelroggen is niet bekend. Deze gebieden maken een beperkt deel uit van het gehele sublitoraal van de Oosterschelde waardoor er met het oog op 
bodemschuifspanning waarschijnlijk voldoende gebied over blijft dat wel gunstig is voor eikapsels, juveniele en (sub) adulte stekelroggen.

De bodemschuifspanning in de Voordelta is gemodelleerd in de PMR-studies (Van Banning \& Adema, 2014). Een aantal kaarten van de bodemschuifspanning is opgenomen in Bijlage 9. Het blijkt dat de bodemschuifspanning zeer variabel is binnen het gebied. De gemiddelde waarden bevinden zich tussen 0 en $0.7 \mathrm{~N} / \mathrm{m}^{2}$ en zijn het hoogste in de winterperiode. Er kunnen enkele keren per jaar veel hogere waarden voor bodemschuifspanning optreden, namelijk tot ca. $10 \mathrm{~N} / \mathrm{m}^{2}$. Die hoge waarden zijn ongunstig voor juveniele stekelrog, maar het deel van de Voordelta waar die waarden optreden is beperkt. Hierdoor wordt de Voordelta m.b.t. de factor bodemschuifspanning als minder geschikt beoordeeld. (Sub)adulte stekelroggen komen in andere gebieden zoals het Kanaal ook relatief frequent voor bij grote bodemschuifspanning en waterstroming. De Voordelta is daarom voor bodemschuifspanning niet beperkend en als gunstig te kwalificeren.

\section{Zoutgehalte}

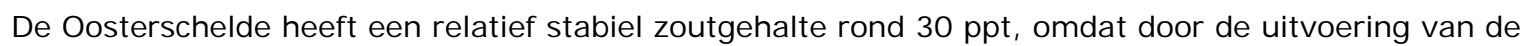
Deltawerken zoetwater aanvoer is geminimaliseerd $\left(25 \mathrm{~m}^{3} / \mathrm{s}\right)$ en de Oosterschelde veranderde van estuarium naar een zoute getijde baai (Schellekens et al., 2012). De saliniteit van de Oosterschelde is relatief stabiel (zie Bijlage 12) en valt binnen de range die gunstig is voor juveniele en (sub)adulte stekelrog.

De saliniteit in de Voordelta bevindt zich in de range: 10-30 ppt, en hoofdzakelijk 25-30 ppt. Lage saliniteit (in de range 10-25 ppt) komt voor bij de monding van het Haringvliet (Van Banning \& Adema, 2014; Bijlage 11). Dit betekent dat de Voordelta m.b.t. saliniteit te kwalificeren is als minder geschikt voor (sub)adulte stekelroggen en geschikt voor juveniele stekelroggen.

\section{Watertemperatuur}

De variatie in de watertemperatuur van de Oosterschelde gedurende het jaar is weergegeven in een grafiek in Bijlage 14 en deze blijkt zeer groot te zijn. De watertemperatuur varieert voornamelijk tussen 5 en $25^{\circ} \mathrm{C}$ (Wijsman \& Smaal 2011). Uit de studie van Martin et al. (2012) is bekend dat stekelroggen in het Kanaal de hogere temperaturen prefereren in de daar voorkomende range 9.5$19^{\circ} \mathrm{C}$, waarbij de juvenielen hogere temperaturen prefereren dan de adulten. Hieruit zou afgeleid kunnen worden dat de temperatuur in de Oosterschelde van november tot april te laag kan zijn voor adulte en vooral voor juveniele stekelroggen. In het voorjaar en de zomer (mei-oktober) is de temperatuur in de Oosterschelde wel gunstig voor stekelroggen. Stekelroggen zullen in dit gebied dus in de winter waarschijnlijk naar diepere wateren gaan en pas in het voorjaar weer naar de ondiepe kustwateren van de Oosterschelde gaan. Het vermogen om deze seizoensmigratie uit te kunnen voeren maakt onderdeel uit van de geschiktheid van een habitat. Stekelroggen voor de Engelse kust vertonen een dergelijke seizoensmigratie, zoals bleek uit experimenten met gemerkte stekelroggen (Walker et al., 1997; Hunter et al., 2005) en beschreven in paragraaf 2.4.

In de Voordelta varieert de maandgemiddelde temperatuur gedurende het jaar tussen 6 en $17^{\circ} \mathrm{C}$ (zie Bijlage 13). De maandgemiddelde temperaturen zijn minimaal $4{ }^{\circ} \mathrm{C}$ (in februari) en maximaal $18{ }^{\circ} \mathrm{C}$, namelijk in augustus. De geschiktheid voor de stekelroggen is sterk afhankelijk van de tijd van het jaar. Deze wordt ingeschat als geschikt in het zomerhalfjaar. De periode december $\mathrm{t} / \mathrm{m}$ april kan de temperatuur minder geschikt zijn voor (sub)adulte stekelroggen en ongeschikt zijn voor juveniele stekelroggen. Voor de stekelroggen in de Voordelta geldt, net zoals hierboven opgemerkt voor de Oosterschelde, dat ze seizoensmigratie moeten kunnen uitvoeren om met deze

temperatuurswisselingen om te gaan. Met behulp van monitoring van gemerkte stekelroggen zou het vermoeden van de seizoensmigratie van stekelroggen van de Oosterschelde en de Voordelta moeten worden aangetoond.

\section{Sedimenttype}

$\mathrm{Er}$ is geen kaart met een gedetailleerde aanduiding van de sedimenttypen van de Oosterschelde gevonden. Uit de kaarten van sediment en droogvalduur (Bijlage 8) en de Ecotopenkaart van de Oosterschelde (Bijlage 14) blijkt dat het sediment van het sublitoraal bestaat uit zacht substraat. Er zijn 3 sublitorale ecotopen: hoogdynamisch sublitoraal, laagdynamisch diep sublitoraal, laagdynamisch 
ondiep sublitoraal. Het is daarom aan te nemen dat het bijbehorende sedimenttype van het hoogdynamische sublitoraal zandig is en dat van de laagdynamische sublitoraal slib tot zandig slib is. Het sedimenttype van de litorale ecotopen wordt wel aangeduid en is hard, fijnzandig, slibrijk. Een relatief groot oppervlak ( $>10 \%$ ) van het gebied is bedekt met oesters op cultuurpercelen en op vlakten (Schellekens et al., 2012).

We kunnen hieruit concluderen dat een groot deel van het sediment van de Oosterschelde bestaat uit zand en slibrijk is. Dit betekent dat het sedimenttype van de Oosterschelde geschikt is voor juveniele stekelroggen en waarschijnlijk ook geschikt is voor (sub)adulte stekelroggen. Uit het voorgaande hoofdstuk blijkt namelijk dat de stekelrog wel gekoppeld kan worden aan een brede range van sedimenttypen (slib, fijn zand, grof zand, gravel, kiezels), maar dat dit leeftijdsafhankelijk is, met voorkeur van juvenielen voor slib en zand, en van (sub)adulten voor zand, gravel en kiezels. In de wetenschappelijke literatuur wordt namelijk vermeld dat (sub)adulten vaker voorkomen boven grover sediment, maar Fock (2014) heeft na analyse geconcludeerd dat dit verdringing van stekelroggen van zand naar grover sediment kan zijn veroorzaakt door langdurende grote visserijdruk.

Een gedetailleerde sedimentkaart van de Voordelta is te vinden in Bijlage 7. Deze kaart is wel ouder want stamt uit de jaren tachtig van de vorige eeuw en is afkomstig van Johan Craeymeersch (WMR). Het slibgehalte van het sediment van de Voordelta is niet hoog en varieert van $0-10 \%$ (www.emodnethydrography.eu). Meer dan 50\% van de oppervlakte van de Voordelta heeft een slibgehalte beneden $5 \%$. Het sedimenttype van de Voordelta is dus grotendeels zandig. Dit is een sedimenttype dat geschikt is voor juveniele stekelrog en waarschijnlijk ook geschikt is voor adulte stekelrog.

Tabel 6 Waarden van milieufactoren in de Oosterschelde en een eerste inschatting van de geschiktheid daarvan voor de stekelrog

\begin{tabular}{|c|c|c|c|c|}
\hline Factoren & Waarden & Reference & $\begin{array}{l}\text { Geschiktheid van } \\
\text { gebied voor } \\
\text { juvenielen (0-1 } \\
\text { groep) }\end{array}$ & $\begin{array}{l}\text { Geschiktheid van } \\
\text { gebied voor } \\
\text { (sub) adulten }(2+ \\
\text { groep) }\end{array}$ \\
\hline Diepte & Tussen 0 en $65 \mathrm{~m}$ & $\begin{array}{l}\text { Schellekens } \\
\text { et al. (2012) }\end{array}$ & Geschikt & Geschikt \\
\hline Dynamiek & $\begin{array}{l}\text { Sublitoraal hoog dynamisch, } \\
\text { Geulen laag dynamisch, Ondiep } \\
\text { laag dynamisch en Middel } \\
\text { litoraal laag dynamisch. Het } \\
\text { grootste deel is } \\
\text { laag dynamisch. }\end{array}$ & $\begin{array}{l}\text { Schellekens } \\
\text { et al. (2012) }\end{array}$ & Geschikt & Geschikt \\
\hline Saliniteit & $\begin{array}{l}\text { Tussen } 28 \text { en } 33 \text { ppt. Data in } \\
\text { grafieken en niet in ruimtelijke } \\
\text { kaart of frequentieverdeling. }\end{array}$ & $\begin{array}{l}\text { Schellekens } \\
\text { et al. (2012) }\end{array}$ & Geschikt & Geschikt \\
\hline $\begin{array}{l}\text { Water- } \\
\text { temperatuur }\end{array}$ & $\begin{array}{l}\text { Tussen } 5 \text { en } 25^{\circ} \mathrm{C}(\text { Wijsman } \& \\
\text { Smaal 2011). }\end{array}$ & $\begin{array}{l}\text { Schellekens } \\
\text { et al. (2012) }\end{array}$ & $\begin{array}{l}\text { Minder geschikt. } \\
\text { Geschiktheid is sterk } \\
\text { afhankelijk van de tijd } \\
\text { van het jaar. Geschikt } \\
\text { van mei-okt en } \\
\text { ongeschikt van nov- } \\
\text { april. }\end{array}$ & $\begin{array}{l}\text { Minder geschikt. } \\
\text { Geschiktheid is sterk } \\
\text { afhankelijk van de tijd } \\
\text { van het jaar. Geschikt } \\
\text { van mei-nov en } \\
\text { ongeschikt van dec- } \\
\text { april. }\end{array}$ \\
\hline $\begin{array}{l}\text { Sediment } \\
\text { type }\end{array}$ & $\begin{array}{l}\text { Hoofdzakelijk zandig en slibrijk. } \\
\text { Een relatief groot oppervlak } \\
\text { (>10 \%) van het gebied is } \\
\text { bedekt met oesters op cultuur } \\
\text { percelen en op vlakten }\end{array}$ & $\begin{array}{l}\text { Schellekens } \\
\text { et al. (2012) }\end{array}$ & Geschikt & Waarschijnlijk geschikt \\
\hline
\end{tabular}


Tabel 7 Waarden van milieufactoren in de Voordelta en een eerste inschatting van de geschiktheid daarvan voor de geschiktheid voor de stekelrog

\begin{tabular}{|c|c|c|c|c|}
\hline Factoren & Waarden & Reference & $\begin{array}{l}\text { Geschiktheid } \\
\text { van gebied voor } \\
\text { juvenielen } \\
\text { ( } 0 \text {-1 groep) }\end{array}$ & $\begin{array}{l}\text { Geschiktheid van } \\
\text { gebied voor } \\
\text { (sub)adulten } \\
\text { ( } 2+\text { groep) }\end{array}$ \\
\hline Diepte & $\begin{array}{l}\text { Diepte } 0-\text { ca. } 25 \mathrm{~m} \text {. met } \\
\text { ca. } 60 \% \text { onder } 10 \mathrm{~m} .\end{array}$ & $\begin{array}{l}\text { Min lenM/RWS } \\
(2016) ; \\
\text { Craeymeersch, } \\
\text { WMR (pers. } \\
\text { med.) }\end{array}$ & Geschikt & Geschikt \\
\hline $\begin{array}{l}\text { Bodemschuif-spanning } \\
\text { (stroming en golven) }\end{array}$ & $\begin{array}{l}\text { Range: } 0-10 \mathrm{~N} / \mathrm{m}^{2} \text {, zeer } \\
\text { variabel binnen het gebied }\end{array}$ & $\begin{array}{l}\text { Van Banning \& } \\
\text { Adema (2014) }\end{array}$ & $\begin{array}{l}\text { Minder geschikt } \\
\text { (deel van het gebied } \\
\text { wel geschikt) }\end{array}$ & Geschikt \\
\hline Zoutgehalte & $\begin{array}{l}\text { Range: } 0 \text { - } 30 \text { ppt. } \\
\text { hoofdzakelijk } 25 \text { - } 30 \text { ppt. }\end{array}$ & $\begin{array}{l}\text { Van Banning \& } \\
\text { Adema (2014) }\end{array}$ & Geschikt & $\begin{array}{l}\text { Minder geschikt. } \\
\text { Groot deel gebied } \\
\text { geschikt. Klein deel } \\
\text { van gebied minder tot } \\
\text { ongeschikt }\end{array}$ \\
\hline Watertemperatuur & Tussen 6 en $17^{\circ} \mathrm{C}$. & $\begin{array}{l}\text { Van Banning \& } \\
\text { Adema } \\
\text { (2014); Smaal } \\
\text { et al. (2017) }\end{array}$ & $\begin{array}{l}\text { Minder geschikt. } \\
\text { Geschiktheid is sterk } \\
\text { afhankelijk van de } \\
\text { tijd van het jaar. } \\
\text { Geschikt van mei- } \\
\text { nov. en ongeschikt } \\
\text { van dec-april. }\end{array}$ & $\begin{array}{l}\text { Minder geschikt. } \\
\text { Geschiktheid is sterk } \\
\text { afhankelijk van de } \\
\text { tijd van het jaar. } \\
\text { Geschikt van mei- } \\
\text { nov. en minder } \\
\text { geschikt van dec.- } \\
\text { april. }\end{array}$ \\
\hline Sediment type & $\begin{array}{l}\text { Slibgehalte } 0-10 \% \text {. Meer } \\
\text { dan } 50 \% \text { van oppervlakte } \\
\text { beneden } 5 \% \text { slib. }\end{array}$ & $\begin{array}{l}\text { Craeymeersch, } \\
\text { WMR (pers. } \\
\text { med.) }\end{array}$ & Geschikt & $\begin{array}{l}\text { Waarschijnlijk } \\
\text { geschikt }\end{array}$ \\
\hline
\end{tabular}

Met de bovenvermelde conclusies van alle behandelde abiotische milieufactoren kunnen voor elk van de gebieden conclusies worden getrokken over de geschiktheid voor de levensstadia van de stekelrog, waarbij ook de ruimtelijke en temporele componenten worden betrokken.

\section{Oosterschelde}

Luvenielen:

De gehele Oosterschelde is geschikt in de periode mei - oktober

Ongeschikt in de periode november - april, vanwege de lage watertemperatuur

(Sub)adulten:

Oosterschelde is geschikt in de periode mei - november

Ondiepe delen van de Oosterschelde zijn minder geschikt in de periode mei - oktober

Gebied is ongeschikt in de periode december - april, vanwege de lage watertemperatuur

\section{Voordelta}

Luvenielen:

Gebied is geschikt in periode mei - november met uitzondering van een klein deel van de Voordelta waar de bodemschuifspanning te hoog is.

Ongeschikt van december - april, vanwege de lage watertemperatuur

(Sub)adulten:

Gebied is minder geschikt in periode mei - oktober en een kleine deel van de Voordelta is ongeschikt (voor Haringvlietbrug) waar de saliniteit laag is.

Gebied is minder geschikt van december - april, vanwege de lage watertemperatuur. 
Het is niet te zeggen of een van beide gebieden geschikter habitat biedt voor juveniele of (sub)adulte stekelroggen. Beide gebieden hebben milieufactoren die in het geprefereerde range liggen en ook milieufactoren die niet optimaal zijn of ongunstig zijn. Met de huidige kennis zijn daar geen verdere conclusies over te trekken.

Het blijkt dat de watertemperatuur voor de habitatgeschiktheid van de stekelrog een milieufactor is met een grote beperking voor beide gebieden. Bodemschuifspanning en saliniteit veroorzaken ook beperkingen maar op een kleinere ruimtelijke of temporele schaal. In november zullen juveniele stekelroggen de Oosterschelde wellicht willen verlaten om in warmere gebieden te overwinteren. In november kunnen deze dieren wellicht nog terecht in de Voordelta omdat de watertemperatuur daar iets hoger is dan in de Oosterschelde, maar daarna zullen ze nog verder moeten trekken naar geschikte overwinteringsgebieden. Men dient voorzichtig te zijn met deze veronderstelling. Humphries et al. (2016) concludeerden namelijk dat de ruimtelijke en temporele verspreiding van stekelroggen in het Kanaal niet werd gestuurd door de temperatuur en in de winter was de temperatuur waarbij de stekelroggen voorkwamen tussen 8.5 en $10.0^{\circ} \mathrm{C}$. Onderzoek met electronic data storage tags aan stekelroggen die worden losgelaten in de Oosterschelde of Voordelta zou uitsluitsel kunnen geven.

\subsection{Biotische factoren}

Biotische factoren kunnen naast abiotische factoren van groot belang zijn voor de geschiktheid van habitats van de stekelrog. De biotische factoren die in de literatuur worden genoemd, als in zijn algemeenheid van belang voor soorten zijn voedselaanbod, concurrentie, predatie, ziekten en parasieten. Deze biotische factoren zijn, voor zover bekend niet specifiek onderzocht in relatie tot de habitatgeschiktheid van gebieden voor de stekelrog. De enige biotische factor waar in de analyse wel nader op kan worden ingegaan is voedselaanbod. Kleine kreeftachtigen zoals garnalen zijn een belangrijk voedseltype voor juveniele stekelroggen. Of garnalen beperkend of niet beperkend aanwezig zijn voor stekelroggen kan niet worden beoordeeld. Dat hangt af van de garnalenproductie en de aanwezigheid van andere garnalenpredatoren (en garnalenvisserij) in het gebied. De kaarten met de garnalendichtheid in Oosterschelde en Voordelta gegevens in Bijlage 4 en de overige voor de periode vanaf 1970 (in de database van WMR) geven een momentopname in september. Over de andere biotische factoren is er momenteel te weinig bekend en daarom kunnen deze voor de Oosterschelde en Voordelta ook niet worden behandeld.

De mening van experts op het gebied van roggen verschilt enigszins met betrekking tot de vraag of zij de Oosterschelde en Voordelta zien als geschikte habitats voor een stekelrogpopulatie. Hiervoor wordt verwezen naar de paragraaf 6.5 in het hoofdstuk Discussie. 


\section{$6 \quad$ Discussie}

\subsection{Data beschikbaarheid stekelrog}

De surveys waarvan de vangstgegevens van stekelroggen in deze studie zijn gepresenteerd, zijn wellicht minder efficiënt voor het monitoren van stekelroggen dan voor de soorten waarvoor de surveys zijn bedoeld. De efficiëntie van de vangst van roggen zal samenhangen met veel factoren, zoals netbreedte, nethoogte, maaswijdte, trekduur, vissnelheid en visperiode (zie Bijlage 2). De verwachte efficiëntie is IBTS>BTS>SNS>DFS wanneer er gevist wordt in dezelfde periode. Maar m.b.t. roggen is de visperiode, namelijk januari-februari, zeer ongunstig voor IBTS. DFS lijkt het minst efficiënt door een smal net, korte trekduur en lage vaarsnelheid. In de Oosterschelde is alleen de DFS uitgevoerd, waardoor dit een zeer beperkt beeld, en daardoor een onderschatting, op levert voor het voorkomen van de stekelrog in dit gebied. Uit de literatuur is bekend dat de vangbaarheid efficiëntie (catchability efficiency) van IBTS voor roggen varieert tussen 7 en 11\% (Fraser et al. 2007; Greenstreet et al. 2007, Piet et al. 2009). Verder worden de surveys slechts in een beperkte periode van het jaar uitgevoerd. Hierdoor wordt er geen inzicht verkregen in de fluctuaties van het voorkomen van stekelroggen gedurende het jaar. Een betrouwbare registratie van de bijvangst van roggen en roggeneikapsels in de commerciële garnalenvisserij in garnalenkorren zonder zeef-lap zou kunnen helpen deze lacune in te vullen (Paddy Walker, persoonlijke mededeling, 19 juni 2017).

De hier gepresenteerde gegevens over aantallen stekelroggen zijn hoofdzakelijk afkomstig van de visserij of van visserijonafhankelijk surveys. Dergelijke studies zijn grootschalig en missen informatie over fijnschalige verspreiding en gedrag. Op sommige locaties vertonen stekelroggen een grote plaatstrouwheid, terwijl elders duidelijke migratie optreedt. Er zijn ook levensfase verschillen zoals met juvenielen die verblijven boven zandige gebieden en oudere individuen die over grotere en diepere gebieden zijn verspreid (Martin et al. 2012). Om fijnschalige verspreiding van stekelroggen te detecteren en de habitatvoorkeur hieruit af te leiden, is gedetailleerd onderzoek, bijvoorbeeld met electronic data storage tags nodig.

De vangstgegevens van de sportvisserij zijn waardevol om meer inzicht te krijgen in de verspreiding en abundantie van roggen in het studiegebied. Roggen zijn namelijk goed met de hengel te vangen. Het aantal vangsten van roggen en haaien in de logboeken van sportvissers was beperkt (van der Hammen \& de Graaf, 2015). Door sportvissers en met weervisserij in de Oosterschelde worden veel meer pijlstaartroggen gevangen dan met surveys. Door een sportvisser is in de Voordelta op augustus 2013 een stekelrog gevangen (Niels Brevé, SVN, pers. meded., 17 juli 2017). Bij de Oosterscheldekering worden meer roggen gevangen hetgeen waarschijnlijk samenhangt met de dynamiek (Niels Brevé, SVN, pers. meded., 17 juli 2017).

\subsection{Abiotische factoren en habitatgeschiktheid}

In het algemeen wordt habitatgebruik door en - geschiktheid voor stekelroggen, en andere kraakbeenvissen, nog onvoldoende begrepen (Humphries et al. 2016). Het is niet bekend of de niches waar roggen worden waargenomen het resultaat is van fundamentele voorkeuren of het gevolg van competitieve interacties (Humphries et al., 2016). Abundantie van soorten is vaak het resultaat van verschillende factoren die op verschillende schaal werken. Zelfs wanneer een omgevingsfactor gunstig is voor de soort, en een andere (onbekende) factor ongunstig is, dan kan de soort absent of beperkt aanwezig zijn (Liebig's law of the minimum) (Cozzoli et al., 2014).

Walker \& Kingma (2013) en Walker et al. (2015) onderzochten de voorwaarden voor succesvol herstel van haaien- en roggenpopulaties in de Noordzee, waarmee ze inzicht verkregen in de factoren die de ontwikkeling van de populaties haaien en roggen beïnvloeden. Er zal eerst een antwoord gegeven moeten worden op de vraag in welk stadium van hun ontwikkeling de inheemse roggensoorten het 
meest gehinderd worden. Sterfte van volwassen roggen, exemplaren in een juveniel stadium of de roggeneieren zelf kunnen de beperkende factor zijn voor de herkolonisatie van het Nederlands Continentale Plat (Walker \& Kingma, 2013). Zij concluderen dat er gebrek is aan data over biologie, voorkomen en verspreiding van vrijwel alle soorten, inclusief de stekelrog. Een belangrijke aanbeveling is om te investeren in de kennisbasis waarop het beleid gebaseerd kan worden.

\subsection{Beperkte biologische kennis}

De biologische kennis over roggen in het algemeen en stekelrog in het bijzonder is beperkt. Dit geldt voor de vier life-history-processen (overleving, groei, reproductie en rekrutering) die de populatiedynamiek bepalen. Daarnaast is ook over de specifieke habitateisen van de stekelrog behorende bij de drie levensstadia (eileg gebieden; kinderkamergebieden; foerageer- en reproductiegebieden) weinig bekend (Walker \& Kingma, 2013). Dat betekent dat er veel onderzoek nodig is om deze kennislacunes op te lossen om daarmee de betrouwbaarheid van evaluaties waaronder habitatgeschiktheidsanalyses van gebieden, zoals in onderhavige studie, te verbeteren.

\subsection{Migratie en bereikbaarheid}

In de inleiding is beschreven dat de stekelroggen in het Theems estuarium en in het Kanaal seizoenmigratie vertonen, maar dat voor de meeste individuen de migratieafstand beperkt blijft tot enkele tientallen kilometers (Hunter et al., 2005). Voor de stekelrog in het Kanaal is die migratieafstand nog beperkter (Humphries et al., 2016). Een klein deel van de stekelroggen van het Theems estuarium migreert echter tot op grote afstanden van meer dan $100 \mathrm{~km}$. Er zou met voorzichtigheid kunnen worden geconcludeerd dat de afstand tussen de Voordelta en het Theems estuarium, die ca. $150 \mathrm{~km}$ bedraagt, goed overbrugbaar is voor stekelroggen. Het is echter onduidelijk of stekelroggen in de herfst vanuit het Theems estuarium in oostelijke richting migreren en dan in redelijke aantallen de Voordelta en eventueel vervolgens de Oosterschelde bereiken. De meest logische periode voor een dergelijke migratie tot in de Voordelta en de Oosterschelde zijn het voorjaar en de zomer, vanwege de dan gunstige temperatuur. Aan het einde van het najaar zullen roggen de Oosterschelde en de Voordelta waarschijnlijk willen verlaten om warmere gebieden te zoeken. Het is onduidelijk welke gebieden dat zullen zijn, maar het is aannemelijk dat dat dezelfde gebieden zullen zijn waar de in het voorjaar en zomer in het buiten Theems estuarium verblijvende stekelroggen in de winter verblijven.

Het is onduidelijk of de Oosterscheldekering een serieuze barrière is voor roggen die van de Voordelta naar de Oosterschelde en vice versa willen verplaatsen. Meer duidelijkheid over dit aspect betreffende de stekelroggen kan worden verkregen door roggen die in het gebied zijn gevangen en weer losgelaten te merken en te volgen. Datzelfde geldt met betrekking tot stekelroggen die in gevangenschap zijn gekweekt en vervolgens worden losgelaten in de Oosterschelde.

Voor populatie-onderzoek is van wezenlijk belang in welke mate de stekelroggen migreren. Als de meerderheid honkvast is, bestaat de mogelijkheid dat er werkelijk verschillende populaties bestaan, die in ruimte van elkaar gescheiden zijn. Er kan dan door toeval nog wel genetische uitwisseling plaatsvinden. Als echter een aanzienlijk deel of zelfs alle roggen op een bepaald moment in hun levensfase de Noordzee rondzwemmen is er dus niet sprake van verschillende populaties. In dat laatste geval is het vooral de vraag waarom de stekelroggen dan nog maar beperkt gebruik maken van de Nederlandse kust.

Daarnaast kan de zogenaamde Occupancy-Abundance relationship een rol spelen bij het verspreidingspatroon van de stekelrog. Als de abundantie toeneemt, neemt een soort meestal meer ruimte in, waardoor minder geschikte habitats ook worden benut. De abundantie van de stekelrog in de Noordzee is dit moment niet heel hoog waardoor ze waarschijnlijk voldoende mogelijkheid hebben om de meest gunstige gebieden uit te kiezen. Dat zijn het Theems estuarium en de Engelse kust. 


\subsection{Expert judgement}

Er zijn aan de twee experts Henk Heessen en Paddy Walker een aantal vragen gesteld die betrekking hebben op de inschatting van de habitatgeschiktheid van gebieden voor stekelroggen.

\section{Vraag 1}

Zijn de Oosterschelde en de Voordelta nu in potentie geschikte habitats voor de stekelrog?

\section{Antwoord van Henk Heessen}

Deze gebieden zijn in potentie geschikt wanneer dat wordt gebaseerd op de abiotische en biotische omstandigheden. Er zijn gebieden zoals het Theems estuarium en het Kanaal waar relatief veel stekelroggen voorkomen en de Oosterschelde en de Voordelta zijn, betreffende de abiotische en biotische factoren, behoorlijk vergelijkbaar. Ondiepe kustwateren zijn blijkbaar geschikte gebieden voor stekelroggen, dus ook de Oosterschelde en de Voordelta. Enkele vormen van visserij zullen bepalend zijn of zich een aanzienlijke stekelrogpopulatie kan opbouwen. In het Theems estuarium is er minder boomkorvisserij dan in de Voordelta. Er wordt daar wel gericht gevist op stekelrog met de beug (lijn met zijlijnen met haken en aas). De nabijheid van de Theems estuarium voor de Voordelta is gunstig voor de populatie in de Voordelta. De data storage tag gegevens van de stekelrog, zoals o.a. vermeld in de Fish Atlas (Heessen et al., 2015), laten zien dat stekelroggen zich bewegen in grotere gebieden.

De bodemschuifspanning is een van de bepalende factoren. Deze zou volgens de literatuur niet groot moeten zijn. Echter in het Kanaal is veel doorstroming en grover sediment en toch komen er relatief meer roggen voor. Dit is moeilijk verklaarbaar. Er is in het Kanaal minder boomkorvisserij dan in de Voordelta en dat zou een verklaring kunnen zijn. Er zijn gevallen bekend van vissoorten waarvan het verspreidingsgebied moeilijk is te relateren aan omgevingsfactoren. Een voorbeeld daarvan is de golfrog die in een beperkt gebied voorkomt (zie Heessen et al., 2015).

\section{Antwoord van Paddy Walker}

Dit weet Paddy Walker niet. Er zijn meerdere kennislacunes is het spel. Het habitat van Oosterschelde en Voordelta is blijkbaar niet erg geschikt, want dan zou de stekelrog daar wel veel meer voorkomen dan nu het geval is. Deze gebieden zijn namelijk wel goed bereikbaar voor stekelroggen vanuit de Oost-Engelse kust waar relatief veel stekelroggen voorkomen en vanuit het offshore gebied waar een recente toename van stekelroggen is opgetreden. Er zouden nog onbekende factoren kunnen zijn die limiterend zijn voor stekelroggen in Oosterschelde en Voordelta. Er is dus meer kennis nodig over deze factoren en de migratie.

Er is waarschijnlijk een gebrek aan goed habitat voor de Hollandse kust (buiten de Zeeuwse Delta en Waddenzee) en dit staat los van de mortaliteit door visserij. Het is onduidelijk wat daarbij precies een rol speelt. Mogelijk blijven de eikapsels niet liggen, vanwege de heersende bodemschuifspanning in combinatie met het ontbreken van een geschikte structuur van en op de zeebodem. Daarnaast is het de vraag of het voedselaanbod en de watertemperatuur gunstig zijn. Dit zijn namelijk belangrijke factoren die de populatiegroei van stekelrog stimuleren (zie ICES, 2016).

Het enige wat je weet is dat als de stekelrog in een gebied over een lange periode veel voorkomt, het gebied voldoet aan de habitateisen van de stekelrog. Dit lijkt in de Noordzee het geval te zijn voor het Kanaal, het Theems estuarium en de Wash. De afwezigheid van stekelroggen kan erop wijzen dat er niet wordt voldaan aan de habitateisen van de stekelrog, maar dat hoeft niet zo te zijn want het kan ook zijn dat de habitateisen wel op orde zijn wat de abiotische en biotische factoren, maar dat er een of meerdere menselijke activiteiten in het gebied optreden die het aantal stekelroggen laag houden.

\section{Vraag 2}

Zijn de habitatkenmerken van het verspreidingsgebied van de stekelrog voldoende in beeld?

\section{Antwoord van Paddy Walker:}

We weten nog onvoldoende over alle van belang zijnde kenmerken van het verspreidingsgebied ( habitateisen) van de stekelrog en ook hoe de kenmerken van de Oosterschelde en de Voordelta zijn. 
De kaarten van de voor habitatgeschiktheid relevante abiotische factoren in de Oosterschelde en Voordelta zijn dus een belangrijk resultaat van deze studie en deze kunnen bijdragen tot meer inzicht.

\section{Vraag 3}

Zijn er naast de in deze analyse betrokken abiotische factoren (diepte, bodemschuifspanning, saliniteit, temperatuur, sediment type) andere abiotische factoren die van groot belang kunnen zijn voor de geschiktheid van habitats van de stekelrog?

\section{Antwoord van Paddy Walker}

Dit is heel goed mogelijk, maar dat zijn kennislacunes. Zoals eerder genoemd is een dergelijke abiotische factor de structuur van de zeebodem die de geschiktheid als eileggebied bepaalt.

De verspreiding van m.n. juveniele stekelroggen kan niet geheel worden verklaard aan de hand van de bekende abiotische factoren, zoals blijkt uit Martin et al. (2012). Er zijn waarschijnlijk andere abiotische en ook menselijke activiteiten die een substantieel effect hebben op de verspreiding van de stekelrog, maar die zijn nog onvoldoende bekend.

\section{Vraag 4}

Is er voldoende voedsel in het uitzetgebied aanwezig waarmee de stekelrog zich kunnen voeden?

\section{Antwoord van Henk Heessen}

Het voedsel voor kleine roggen is in overvloed aanwezig. Dat voedsel bestaat uit kleine kreeftachtigen (garnalen).

\section{Antwoord van Paddy Walker:}

$\mathrm{Er}$ is waarschijnlijk wel voldoende aanwezig. Hierbij is gunstig dat stekelroggen opportunisten zijn.

\section{Vraag 5}

Wat is er bekend over de biotische factoren, behalve voedselaanbod, die voor de stekelrog van belang zijn voor de geschiktheid van habitats van de stekelrog?

Antwoord van Paddy Walker:

Het voorkomen en de invloed van predatie op en ziekten en plagen voor de stekelrog zijn niet bekend, maar kunnen belangrijk blijken te zijn.

\section{$\underline{\text { Vraag } 6}$}

Zijn er menselijke activiteiten in de Oosterschelde en de Voordelta die de ontwikkeling van een stekelrogpopulatie kunnen belemmeren?

\section{Antwoord van Henk Heessen}

Intensieve boomkorvisserijen en garnalenvisserij zullen de opbouw van een stekelrogpopulatie onmogelijk maken. Dit speelt dus een belangrijke rol in de Nederlandse kustwateren.

\section{Antwoord van Paddy Walker:}

De stekelrog heeft een beperkte verspreiding en veel beperkter in de Noordzee dan decennia geleden het geval was. Langs de Engelse oostkust en in het Kanaal komt de stekelrog echter nog steeds in redelijke aantallen voor en dit is alleen mogelijk als de soort zich op beschermde plaatsen kan ophouden. Dat deze soort verdwenen is uit grote gedeelten van de Noordzee, komt waarschijnlijk door de daar plaatsvindende bodemvisserij (Walker, 1999). Zandsuppletie wordt ook gezien als een belangrijke menselijke activiteit die het habitat van stekelroggen ongeschikt kan maken. Over de exacte omvang is nog weinig bekend. 
Vraag 7

Is er ook een seizoen dat het meest geschikt is voor het uitzetten van stekelroggen?

\section{Antwoord van Henk Heessen}

Dit is heel moeilijk te zeggen. Het winterseizoen zou vanwege de lage temperaturen geschikter zijn wanneer wordt nagestreefd het stressniveau voor de uitgezette stekelroggen zo laag mogelijk te houden.

\section{$\underline{\text { Vraag } 8}$}

Zijn er binnen het gebied ook locaties die het meest geschikt zijn voor het uitzetten van stekelroggen?

\section{Antwoord van Henk Heessen}

De aanbeveling is te kiezen voor het uitzetten van stekelroggen voor gebieden binnen de Oosterschelde en Voordelta waarin niet wordt gevist.

Antwoord van Paddy Walker:

Dit is nu niet bekend. Eerst moet worden bekeken hoe dit gebied er op een gedetailleerde schaal uitziet. Bovendien moet er ook worden bestudeerd hoeveel stekelroggen en van welk stadium erop welke plaats zijn gevangen.

De stekelroggen moeten niet worden uitgezet in gebieden waar zandsuppleties of relatief veel visserij voorkomen. We weten niet wat de jonge stekelroggen willen en welke gebieden ze dus opzoeken. Een advies is wel een plek in de Oosterschelde en de Voordelta te kiezen waar ze eerder zijn gevangen. De locaties waar juveniele stekelroggen zijn gevangen kunnen een goede habitat zijn. Dat hoeven daarmee nog geen geschikte habitats voor de adulte stekelroggen te zijn.

\section{$\underline{\text { Vraag } 9}$}

Wat is een geschikte leeftijd van jonge stekelrog, in de range tussen de 0 en 1 jaar, om uitgezet te worden?

\section{Antwoord van Henk Heessen}

De stekelroggen zouden groter en dus ouder moeten zijn in geval deze vlak voordat ze worden uitgezet, worden voorzien van een merk.

\section{Toelichting van Michael Laterveer}

Op dit moment (augustus 2017) worden de data van de groeicurven en voedselopname van stekelrog jongen gedurende de eerste 12 levensmaanden uitgewerkt. De omgevingstemperatuur speelt hierbij een rol, waarbij er een snellere ontwikkeling is bij hogere temperatuur. Na 3 maanden nemen de jonge roggen ook garnalen aan als voedsel wat gunstig is voor de overlevingskansen in het wild. Fysiek kunnen er pas na zo'n 9 maanden merkjes (tags) op de dieren worden aangebracht. Dit laatste is bepalend voor de leeftijd waarop de dieren gemerkt uitgezet kunnen worden. Tag-retentie onderzoek is nu gaande in het kweekcentrum met 55 dieren en 4 type merkjes. Roggen herstellen snel van wonden, er is geen uitval en normaal gedrag bij alle type tags.

\section{Antwoord van Paddy Walker:}

Dat is niet bekend omdat we niet weten wat juveniele stekelroggen nodig hebben en hoe dat varieert met de leeftijd.

\section{Vraag 10}

Zijn er in de Nederlandse kustwaren andere gebieden die even geschikt of geschikter zouden kunnen zijn voor het uitzetten van jonge SR?

\section{Antwoord van Henk Heessen}

De Waddenzee zou in potentie ook een geschikte habitat voor stekelroggen kunnen zijn indien daar niet of beperkt wordt gevist met de garnalenkor. Dat is momenteel echter niet het geval. 
Antwoord van Paddy Walker:

De Waddenzee is hiervoor een kandidaat. Echter om verschillende gebieden langs de Nederlandse kust met elkaar te kunnen vergelijken op habitatgeschiktheid, zou er een habitatgeschiktheidsanalyse kunnen worden gedaan met de heersende abiotische en biotische factoren en de vangstgegevens van stekelroggen.

\section{$\underline{\text { Vraag } 11}$}

Kunnen waarden voor aantreffen van stekelroggen op de Noordzee, of specifiek in de Voordelta en de Oosterschelde, ook worden omgezet van aantal $(n)$ per uur visserij (IBTS) per oppervlakte-eenheid (1/4 ICES-kwadrant $\left(15 \times 15 \mathrm{~nm}\right.$ or $\left.780 \mathrm{~km}^{2}\right)$ naar een populatieomvang in de eenheid aantal $(\mathrm{n})$ per oppervlakte-eenheid $\left(\mathrm{n} / \mathrm{km}^{2}\right)$ ?

\section{Antwoord van Henk Heessen}

De vangbaarheid als percentage van het deel van de vissen die aanwezig zijn in het beviste oppervlak is van belang om te weten dan wel goed te kunnen schatten. Hierover zijn erg weinig gegevens beschikbaar. De omrekening introduceert veel onbetrouwbaarheid want dit is moeilijk te schatten en er moeten flinke aannames worden gedaan.

\section{Vraag 12}

Welke aanbevelingen stelt u voor?

\section{Antwoord van Henk Heessen}

Onderzoek aan de stekelrog in het Nederlands gebied is moeilijk omdat stekelrog zo weinig voorkomt. Het uitrusten van uit te zetten stekelroggen met data storage tags kan zeer interessante informatie opleveren over gedrag, diepte en migratie. Zie hiervoor pagina 116 in Fish Atlas over de stekelrog (Heessen et al., 2015). Het nadeel kan zijn dat DST in verhouding erg groot zijn voor juveniele stekelrog. Ook het toepassen van gewone merken en melden van terugvangsten is zinvol.

\section{Antwoord van Paddy Walker}

Onderzoek doen in de Nederlandse kustgebieden, zoals Oosterschelde, Voordelta en Waddenzee met camera's, tags, monitoring met visserij en surveys. Heel interessant zou een onderzoek zijn met garnalenkor, zonder zeef-lap, om bijvangst van roggen (eikapels, juvenielen, e.d.) te kunnen meten. Navraag binnen WMR leerde dat de demersal surveys technisch gezien op dit punt al geschikt, want ze zijn gericht op de vangst van kleine en jonge vis. Een belangrijk verschil tussen de visserij van de garnalenvloot en de DFS en MVII monitoring is de effort. Deze is veel groter bij de garnalenvisserij.

Met name experimenten met data storage tags zijn aan te raden. De technieken zijn sterk verbeterd. E DNA als methode is ook zinvol. In Australië zijn er goede resultaten mee gehaald, maar niet in alle andere regio's (Paddy Walker).

Onderzoek naar de structuur en het reliëf van de zeebodem vanwege de betekenis voor het aanhechten van eikapsels en het bieden van bescherming aan zeer jonge stekelroggen is aan te raden.

Daarnaast is modellering van habitatgeschiktheid voor de stekelrog aan te raden.

\section{Synthese}

Uit bovenstaande antwoorden blijkt dat de beide experts het over de meeste aspecten een vergelijkbare mening hebben, maar niet over alle aspecten. De experts verschillen namelijk van mening met betrekking tot de belangrijke vraag of de Oosterschelde en de Voordelta momenteel geschikte habitats voor de ontwikkeling van een stekelrog populatie zouden kunnen zijn in het geval de invloed van menselijke activiteiten, zoals visserij en zandsuppleties, buiten beschouwing wordt gelaten. Henk Heessen is van mening dat het habitat wel geschikt is, terwijl Paddy Walker zegt dat ze niet weet of het habitat wel of niet geschikt is. Volgens Paddy Walker is er nog onvoldoende bekend 
over alle van belang zijnde kenmerken van het verspreidingsgebied (habitateisen) van de stekelrog en ook hoe de kenmerken van de Oosterschelde en de Voordelta zijn. De lacunes in de habitateisen van de stekelrog zijn algemeen want die gelden niet specifiek voor de studiegebieden. Deze zullen daarom waarschijnlijk door onderzoekers van roggen in andere gebieden worden bestudeerd. Het is belangrijk dit te blijven volgen. De beide experts zijn het eens over het grote belang van onderzoek aan in Nederlandse wateren uitgezette stekelroggen met DST en andere merken. Dit sluit aan bij het plan van SVN en WNF om het succes van het uitzetten van de gekweekte stekelroggen te monitoren omdat er informatie nodig is over de verspreiding en de overleving. Verspui (in prep.) heeft ter voorbereiding daarvan de verschillende typen tags, met het gebruik en de voor- en nadelen, beschreven in een achtergronddocument. Hiermee kunnen de meeste geschikte tags gekozen voor het traceren van individuen voor langere perioden zonder significante invloed op foerageren en groei. 


\section{$7 \quad$ Conclusies en aanbevelingen}

\subsection{Conclusies}

Uit de gegevens over vangsten van stekelroggen in Nederlandse aanlandingen en surveys in Oosterschelde en Voordelta blijkt dat deze soort sporadisch wordt aangetroffen. Er is momenteel dus geen sprake van een stekelrogpopulatie in deze gebieden. Er kan daarom ook geen habitatgeschiktheidsanalyse worden gedaan m.b.v. correlaties tussen presentie van stekelroggen en omgevingsfactoren in Oosterschelde en Voordelta. Wel kan er gebruik worden gemaakt van correlaties die reeds zijn vastgesteld in andere gebieden in of nabij de Noordzee, waar stekelroggen relatief veel voorkomen (o.a. Theems estuarium, het Kanaal).

Op basis van de abiotische factoren (diepte, bodemschuifspanning, saliniteit, temperatuur en sediment type) en de biotische factor voedselaanbod (garnalen) zouden Oosterschelde en Voordelta van het voorjaar tot de late herfst geschikt kunnen zijn als habitat voor stekelroggen. De watertemperatuur is in de wintermaanden beperkend in Oosterschelde en Voordelta. Saliniteit en bodemdynamiek kan beperkend zijn in een klein deel van de Voordelta. De habitateisen verschillen tussen enerzijds juveniele ( 0 en 1 jarig) en anderzijds subadulte en adulte ( $2+$ jarige) stekelroggen.

Het is niet te zeggen of een van beide gebieden geschikter habitat biedt voor juveniele of (sub)adulte stekelroggen. Beide gebieden hebben milieufactoren die in het geprefereerde range liggen en ook milieufactoren die niet optimaal zijn of ongunstig zijn. Met de huidige kennis zijn daar geen verdere conclusies over te trekken.

Het is mogelijk dat er andere factoren zijn die mede het habitat bepalen. Het is niet bekend welke abiotische factoren dat zijn. Dit geldt bijvoorbeeld m.b.t. structuren op de bodem voor het afzetten van eikapsels. Daarnaast is te veronderstellen dat er biotische factoren zijn die hierbij een sturende rol spelen. Het voedselaanbod van juveniele stekelroggen lijkt voldoende te zijn en voor subadulte en adulte stekelroggen is dat waarschijnlijk ook het geval. Dit is echter niet met zekerheid te zeggen, want de concurrentie met andere predatoren van garnalen is niet bekend. Andere biotische factoren zijn predatie op eikapsels en juveniele stekelroggen en parasieten en ziekten. Daarvan is niet bekend welke rol deze kunnen hebben.

Uit de analyse op basis van de gegevens uit de literatuur en de mening van de betrokken experts blijkt dat het nog niet mogelijk is een schatting te geven voor het huidige en toekomstige aantal (dichtheid) stekelroggen per oppervlakte-eenheid in Oosterschelde en Voordelta.

In deze studie is geen analyse gemaakt van de invloed van menselijke activiteiten op de stekelroggen. De wetenschappelijke literatuur en de experts wijzen er wel op dat intensieve boomkorvisserij en garnalenvisserij stekelrog populaties hebben gereduceerd en de opbouw van populaties in de weg zullen staan.

\subsection{Aanbevelingen}

De volgende aanbevelingen worden gedaan:

- Onderzoek naar de invloed van een aantal biotische factoren, zoals predatie op eikapsels en juveniele stekelroggen, en parasieten en ziekten.

- Onderzoek naar de betekenis van de structuur en het reliëf van de zeebodem voor het aanhechten van eikapsels en het bieden van bescherming aan zeer jonge stekelroggen. Afhankelijk daarvan onderzoek naar de aanwezigheid van structuur en het reliëf van de zeebodem in de Oosterschelde en de Voordelta. 
- Uitvoeren van een kwantitatieve habitatgeschiktheidsanalyse met rekenregels en GIS om daarmee een voorspelling te doen van de (relatieve) habitatgeschiktheid van de stekelrog binnen de Oosterschelde en de Voordelta.

- Gezien de aannames en onzekerheden is empirische toetsing van de conclusies via een pilotexperiment en monitoring een noodzakelijke stap in de verdere ontwikkeling van stekelrogpopulatie in de Oosterschelde en de Voordelta en breder dan dat in de Zeeuwse Deltawateren. Het merken van alle uit te zetten individuen met externe merken, is essentieel om de verspreiding te kunnen volgen (merk-terugvangst). Een aantal zou ook met electronische data storage tags (DSTs) of inwendige zenders moeten worden uitgerust want dit levert meer informatie op.

- Studie naar de impact van menselijke activiteiten (o.a. visserij, zandsuppletie, klimaatverandering) op verspreiding en abundantie van de stekelrog.

- Verbetering van de identificatie van roggensoorten bij aanlandingen.

- De trapsgewijze aanpak van de habitatgeschiktheidsanalyse die is toegepast in deze studie (zie paragraaf 1.3) kan ook dienen als voorbeeld voor habitatgeschiktheidsanalyse voor andere roggen- en haaiensoorten in dit gebied. 


\section{Dankwoord}

De auteurs bedanken Niels Brevé (Sportvisserij Nederland) en Monique van de Water (Wereld Natuur Fonds) voor het verlenen van de opdracht en voor hun waardevol commentaar op de conceptversie. Dat laatste geldt ook voor Michaël Laterveer van Blue Linked. Onze dank gaat ook uit naar Johan Craeymeersch, Jeroen Wijsman, Erwin Winter, Henk Heessen en Paddy Walker die hun kennis hebben ingebracht betreffende de gebieden, surveys, ecologie van roggen, en Oscar Bos voor de review van het rapport.

\section{$9 \quad$ Kwaliteitsborging}

Wageningen Marine Research beschikt over een ISO 9001:2008 gecertificeerd kwaliteitsmanagementsysteem (certificaatnummer: 187378-2015-AQ-NLD-RvA). Dit certificaat is geldig tot 15 september 2018. De organisatie is gecertificeerd sinds 27 februari 2001. De certificering is uitgevoerd door DNV Certification B.V. 


\section{Literatuur}

Chevolot, M., J.R. Ellis, G. Hoarau, A.D. Rijnsdorp, Wytze T. Stam, Jeanine L. Olsen (2006) Population structure of the thornback ray (Raja clavata L.) in British waters J ournal of Sea Research 56 (2006) 305-316.

Cozzoli F, M. Eelkema, T.J. Bouma, T. Ysebaert, V. Escaravage et al. (2014) A Mixed Modeling Approach to Predict the Effect of Environmental Modification on Species Distributions. PLoS ONE 9(2): e89131. doi: 10.1371/journal. pone.0089131.

Dedman, S., R. Officer, D. Brophya, M. Clarke, D.G. Reid (2015) Modelling abundance hotspots for data-poor I rish Sea rays. Ecological Modelling 313: 77-90.

EC (2017) http://ec.europa.eu/fisheries/cfp/fishing_rules/discards/index_en.htm

Ellis, J., Dulvy, N., Walls, R. \& Serena, F. (2016) Raja clavata. The IUCN Red List of Threatened Species 2016: e.T39399A103111648. Downloaded on 31 July 2017. http://www. iucnredlist.org/details/39399/1

Fock, H. (2014) Patterns of extirpation. I. Changes in habitat use by thornback rays Raja clavata in the German Bight for 1902-1908, 1930-1932, and 1991-2009. Endangered Species Research 25: 197-207.

Fraser H.M., S.P.R. Greenstreet \& G.J. Piet (2007) Taking account of catchability in groundfish survey trawls: implications for estimating demersal fish biomass. ICES J ournal of Marine Science 64: 1800-1819.

Glorius, S.T., K.E. van de Wolfshaar, I. Tulp (2012) Abundance patterns of six fish species in the shallow coastal zone in The Netherlands. Report number C101/12.

Greenstreet, S.P.R., H. Fraser, G.J. Piet, L. Robinson, R. Callaway, H. Reiss, S. Ehrich, I. Kroncke \& J.A.M. Craeymeersch (2007) Species composition, diversity, biomass and production of the demersal fish community of the North Sea. Aberdeen : Fisheries Research Services Marine Laboratory, (Fisheries research services collaborative report no. 07/07) - 94 p.

Greenway, E., K.S. Jones, G.M. Cooke (2016) Environmental enrichment in captive juvenile thornback rays, Raja clavata (Linnaeus 1758). Applied Animal Behaviour Science 182 (2016) 86-93. http://dx.doi.org/10.1016/j.applanim.2016.06.008.

Heessen, H.J.L., N. Daan \& J.R. Ellis (2015) Fish atlas of the Celtic Sea, North Sea, and Baltic Sea. Based on international research-vessel surveys. Wageningen Academic Publishers, KNNV Publishing, The Netherlands.

Henkens, R.J.H.G., J.W.M. Wijsman, C.M. Goossen \& R. Jochem (2012) Duurzaam ruimtegebruik Oosterschelde; Toepassing van PARENA (Praktische Aanpak REcreatie en NAtuur) voor een duurzame combinatie van natuur, recreatie en schelpdiervisserij. Wageningen, Alterra, Alterrarapport 2284.

Humphries, N.E., S.J. Simpson, V.J. Wearmouth, D.W. Sims (2016) Two's company, three's a crowd: fine-scale habitat partitioning by depth among sympatric species of marine mesopredator. Marine Ecology Progress Series 561: 173-187. doi: 10.3354/meps11937.

Hunter, E., A.A. Buckley, C. Stewart \& J.D. Metcalfe (2005) Migratory behaviour of the thornback ray, Raja clavata, in the southern North Sea. J. Mar. Biol. Ass. U.K. 85, 1095-1105.

ICES (2016) Report of the Working Group on Elasmobranch Fishes (WGEF), 15-24 June 2016, Lisbon, Portugal. ICES CM/ACOM:20. 26 pp.

IUCN/SSC (2013) Guidelines for Reintroductions and Other Conservation Translocations. Version 1.0. Gland, Switzerland: IUCN Species Survival Commission, viiii + 57 pp.

Lauria, V., M. Gristina, M.J. Attrill, F. Fiorentino \& G. Garofalo (2015) Predictive habitat suitability models to aid conservation of elasmobranch diversity in the central Mediterranean Sea. Scientific Reports | 5: 13245 | DOI: 10.1038/srep13245.

Martin CS, Vaz S, Ellis JR, Lauria V, Coppin F, Carpentier A (2012) Modelled distributions of ten demersal elasmobranchs of the eastern English Channel in relation to the environment. Journal of Experimental Marine Biology and Ecology, 418-419, 91-103. 
Maxwell, D.L., V. Stelzenmüller, P.D. Eastwood \& S.I. Rogers (2009) Modelling the spatial distribution of plaice (Pleuronectes platessa), sole (Solea solea) and thornback ray (Raja clavata) in UK waters for marine management and planning Journal of Sea Research 61 (2009) 258-267.

Ministerie LNV (2009) Aanwijzingsbesluit Natura 2000-gebied Oosterschelde.

Ministerie van Infrastructuur en Milieu | Rijkswaterstaat (2016): Beheerplan Natura 2000 Voordelta.

Piet, G.J., van Hal R., Greenstreet S.P.R. (2009) Modelling the direct impact of bottom trawling on the North Sea fish community to derive estimates of fishing mortality for non-target fish species. ICES Journal of Marine Science 66: 1985-1998.

Schellekens, T., J.W.M. Wijsman, A. v.d. Brink (2012) A habitat suitability model for Pacific oysters (Crassostrea gigas) in the Oosterschelde Report number C057/11.

Sguotti, C., C.P. Lynam, B. Garcia-Carreras, J.R. Ellis, G.H. Engelhard (2016) Distribution of skates and sharks in the North Sea: 112 years of change. Global Change Biology (2016) 22, 2729-2743, doi: $10.1111 /$ gcb.13316.

Smaal, A., P. Kamermans, F. Kleissen, L. van Duren \& T. van der Have (2017) Platte oesters in offshorewindparken (POP). Wageningen, Wageningen Marine Research rapport C035/17. https://doi.org/10.18174/412950

Teal, L.R., et al. (2015) Physiology-based modelling approaches to characterize fish habitat suitability: Their usefulness and limitations, Estuarine, Coastal and Shelf Science, http://dx.doi.org/10.1016/j.ecss.2015.11.014

Van Banning, G. \& J. Adema (2014) PMR monitoring natuurcompensatie. Voordelta. Eindrapport le fase 2009-2013. Deel B. 7 Perceel Abiotiek. ARCADIS/Alkyon, ( ) Deltares.

Van der Hammen, T. \& M. de Graaf (2015) Recreational fisheries in the Netherlands: analyses of the 2012-2013 online logbook survey, 2013 online screening survey and 2013 random digit dialing screening survey. I MARES rapport C042/15. http://edepot. wur.nl/338449.

Van Hal (2005) RIVO Jaarrapportage Zoute Wateren 2004: monitoring van de visgemeenschap en de visserij. Intern rapport. Nummer: 05.009. http://edepot. wur.nl/148270.

Van Overzee, H.M.J., M.L. Kraan \& F.J. Quirijns (2014) Beleidsondersteunend onderzoek haaien en roggen. IMARES Rapport C009/14, 62 p.

Verspui, R. (in prep.) Background research for the reintroduction of sharks and rays in the North Sea an overview of tags used for studying elasmobranchs. Draft document, date: 03-05-2016, Sportvisserij Nederland.

Walker, P. \& I. Kingma (2013) Onderzoek naar haaien en roggen in Nederland in het kader van de Kaderrichtlijn Mariene Strategie. Eindrapportage fase 1: Referentiesoorten bepalen. Rapport van de Nederlandse Elasmobranchen Vereniging.

Walker, P. (1996) Ecoprofile rays and skates on the Dutch continental shelf and North Sea. Rapport RIKZ-96.005; NIOZ Publication No.: 3053. 76 pp.

Walker, P. A. \& H.J.L Heessen (1996) Long-term changes in ray populations in the North Sea. - ICES Journal of Marine Science, 53: 1085-1093.

Walker, P. A., Howlett, G. \& Millner, R. (1997) Distribution, movement and stock structure of three ray species in the North Sea and eastern English Channel. - ICES Journal of Marine Science, 54: 797808.

Walker, P., I. Kingma, M. van de Water, A. De Blaeij \& WJ. Strietman (2015) Onderzoek naar haaien en roggen in Nederland in het kader van de Kaderrichtlijn Mariene Strategie. Eindrapportage fase 2: Voorwaarden voor herstel van Haaien- en Roggenpopulaties in de Noordzee. Rapport van de Nederlandse Elasmobranchen Vereniging, LEI-Wageningen UR \& WING.

Walker, P.A. (1999) Fleeting images: Dynamics of North Sea Ray populations. PhD Thesis, University of Amsterdam, the Netherlands, $145 \mathrm{pp}$.

Wijsman, J.W.M. \& A.C. Smaal (2011) Growth of cockles (Cerastoderma edule) in the Oosterschelde described by a Dynamic Energy Budget model. Journal of Sea Research 66 (2011) 372-380.

Winter, H.V., L.R. Teal, K.E. van de Wolfshaar, A.B. Griffioen, B. Houben, N.W.P. Brevé (2015) Deskstudy on habitat quality for the European Sturgeon in the Dutch Rhine and southern North Sea. I MARES Report number C044/15. 


\section{Verantwoording}

Rapport C059/17

Projectnummer: 431.51000 .69

Dit rapport is met grote zorgvuldigheid tot stand gekomen. De wetenschappelijke kwaliteit is intern getoetst door een collega-onderzoeker en het verantwoordelijk lid van het managementteam van Wageningen Marine Research

Akkoord:

Dr. O.G. Bos

Handtekening:

Datum:

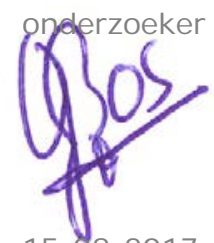

15-88-2017

Akkoord:

Drs. J. Asjes

MT-lid

Handtekening:

Datum:

16-08-2017 


\section{Bijlage 1 IUCN/SSC richtlijnen voor herintroductie van soorten}

Selectie uit de richtlijnen van IUCN/SSC (2013) van teksten die het meest relevant zijn met het oog op een habitatgeschiktheidsanalyse ten behoeve van de introductie van gekweekte juveniele stekelroggen in de Oosterschelde. Deze selectie is niet volledig en het wordt aanbevolen ook de volledige tekst van de richtlijnen van IUCN/SSC (2013) te raadplegen.

Referentie: I UCN/ SSC (2013). Guidelines for Reintroductions and Other Conservation Translocations. Version 1.0. Gland, Switzerland: I UCN Species Survival Commission, viiii + 57 pp. (https:/ / portals.iucn.org/ library/ sites/ library/ files/ documents/ 2013-009.pdf)

\section{Section 1 I ntroduction and scope of Guidelines}

These Guidelines focus on conservation translocations, namely a translocation that yields quantifiable conservation benefit. For this purpose the beneficiaries should be the populations of the translocated species, or the ecosystems that it occupies. Situations in which there is benefit only to the translocated individuals do not meet this requirement.

\section{Section 2 Definitions and classification}

Conservation translocations can entail releases either within or outside the species' indigenous range. The indigenous range of a species is the known or inferred distribution generated from historical (written or verbal) records, or physical evidence of the species' occurrence.

1. Population restoration is any conservation translocation to within indigenous range, and comprises two activities:

a. Reinforcement is the intentional movement and release of an organism into an existing population of conspecifics.

Reinforcement aims to enhance population viability, for instance by increasing population size, by increasing genetic diversity, or by increasing the representation of specific demographic groups or stages.

\section{Section 5 Feasibility and design}

5.1.1 Basic biological knowledge 1. Necessary knowledge of any translocation candidate species should include its biotic and abiotic habitat needs, its interspecific relationships and critical dependencies, and its basic biology.

\subsubsection{Habitat}

Feasibility and design

1. While reintroduction into indigenous range is always preferable, previous indigenous range may no longer be suitable habitat depending on ecological dynamics during the extinction period.

2. The last place in which a species/population was found may not be the best habitat for returning the species.

3. Suitable habitat should meet the candidate species' total biotic and abiotic needs through space and time and for all life stages. 
5.1.3 Climate requirements

1. The climate at destination site should be suitable for the foreseeable future.

\section{Section 7 Release and implementation}

7.1 Selecting release sites and areas

A release area should:

- Meet all the species' biotic and abiotic requirements,

- Be appropriate habitat for the life stage released and all life stages of the species,

- Be adequate for all seasonal habitat needs,

- Be large enough to meet the required conservation benefit,

- Have adequate connectivity to suitable habitat if that habitat is fragmented,

- Be adequately isolated from suboptimal or non-habitat areas which might be sink areas for the population.

\section{Section 8 Monitoring and continuing management}

\subsection{Monitoring}

3. The monitoring programme (Guidelines Section 4.3) is the means to measure the performance of released organisms against objectives, to assess impacts, and provide the basis for adjusting objectives or adapting management regimes or activating an exit strategy.

- Demographic performance Key aspects for any translocation should include monitoring of population growth and/or spread; more intensive monitoring to estimate individual survival, reproduction and dispersal may be needed depending on circumstances.

- Behavioural monitoring Monitoring the behaviour of translocated individuals can be a valuable, early indicator of translocation progress; but its value depends on comparative data from either comparable natural populations or the same individuals before removal from their source population.

\section{Annex 5 Feasibility and design}

3. Background ecological knowledge should include biotic and abiotic habitat requirements, intraspecific variation, adaptations to local ecological conditions, seasonality and phenology, dispersal, and interspecific relationships including feeding, predation, disease, commensalism, symbioses and mutualisms.

15. As even the most detailed habitat assessments may not capture the full range of environmental variation during the lifespan of individuals of the focal species, the loss through death or dispersal of translocated individuals at some sites or in particular years should be expected. 


\section{Bijlage 2 Kenmerken van surveys}

$\begin{array}{llllll} & \text { IBTS } & \text { BTS } & \text { MVII } & \text { DFS } & \text { DFS } \\ \text { Net } & \text { GOV } & 8 \mathrm{~m} \text { boomkor } & 6 \mathrm{~m} \text { boomkor } & 6 \mathrm{~m} \text { boomkor } & 3 \text { boomkor } \\ \text { Breedte (m) } & 20 & 8 & 6 & 6 & 3 \\ \text { Hoogte (m) } & 5 & 1 & 1 & 1 & 1 \\ \text { Maaswijdte (mm gestrekt) } & 16 & 40 & 20 & 20 & 20 \\ \text { Trekduur (min) } & 30 & 30 & 15 & 15 & 15 \\ \text { Vissnelheid (knopen) } & 4 & 4 & 2.5 & 2-3 & 2-3 \\ \text { Periode (maanden) } & \text { jan-feb } & \text { aug-sep } & \text { sep-okt } & \text { sep-okt } & \text { sep-okt } \\ \text { Gebied (m.b.t. deze studie) } & \text { Voordelta } & \text { Voordelta } & \text { Voordelta } & \text { Voordelta } & \text { Oosterschelde } \\ \text { Doelsoorten } & \text { Wijting } & \text { Schol } & \text { Schol } & \text { Schol } & \text { Schol } \\ & \text { Kabeljauw } & \text { Tong } & \text { Tong } & \text { Tong } & \text { Tong } \\ & \text { Schelvis } & \text { Schar } & \text { Schar } & \text { Schar } & \text { Schar }\end{array}$

Bron: Van Hal (2005): RIVO J aarrapportage Zoute Wateren 2004: monitoring van de visgemeenschap en de visserij. Intern rapport. Nummer: 05.009. http://edepot.wur.nl/148270 


\section{Bijlage 3 Inspanning demersal surveys Voordelta}

Aantal vis trekken in de Voordelta per survey, jaar en kwartaal.

\begin{tabular}{|c|c|c|c|c|c|}
\hline Jaar & Kwartaal & BTS & DFS & IBTS & MVII \\
\hline 1970 & 3 & & 5 & & \\
\hline \multirow[b]{2}{*}{1971} & 3 & & 2 & & \\
\hline & 4 & & 5 & & \\
\hline \multirow[b]{2}{*}{1972} & 2 & & 5 & & \\
\hline & 4 & & 8 & & \\
\hline \multirow[b]{2}{*}{1973} & 2 & & 5 & & \\
\hline & 4 & & 7 & & \\
\hline \multirow[b]{2}{*}{1974} & 2 & & 5 & & \\
\hline & 4 & & 12 & & \\
\hline \multirow[b]{2}{*}{1975} & 2 & & 9 & & \\
\hline & 3 & & 12 & & \\
\hline \multirow[b]{3}{*}{1976} & 2 & & 5 & & \\
\hline & 3 & & 8 & & \\
\hline & 4 & & 1 & & \\
\hline \multirow[b]{2}{*}{1977} & 2 & & 8 & & \\
\hline & 4 & & 17 & & \\
\hline \multirow[b]{2}{*}{1978} & 2 & & 15 & & \\
\hline & 4 & & 10 & & \\
\hline \multirow[b]{2}{*}{1979} & 2 & & 9 & & \\
\hline & 4 & & 8 & & \\
\hline \multirow[b]{3}{*}{1980} & 2 & & 17 & & \\
\hline & 3 & & 10 & & \\
\hline & 4 & & 5 & & \\
\hline \multirow[b]{3}{*}{1981} & 2 & & 17 & & \\
\hline & 3 & & 15 & & \\
\hline & 4 & & 3 & & \\
\hline \multirow[b]{3}{*}{1982} & 2 & & 19 & & \\
\hline & 3 & & 6 & & \\
\hline & 4 & & 14 & & \\
\hline \multirow[b]{3}{*}{1983} & 2 & & 19 & & \\
\hline & 3 & & 17 & & \\
\hline & 4 & & 1 & & \\
\hline \multirow[b]{2}{*}{1984} & 2 & & 7 & & \\
\hline & 4 & & 16 & & \\
\hline \multirow[b]{3}{*}{1985} & 2 & & 8 & & \\
\hline & 3 & & 5 & & \\
\hline & 4 & & 14 & & \\
\hline \multirow[t]{3}{*}{1986} & 2 & & 7 & & \\
\hline & 3 & & 5 & & \\
\hline & 4 & & 11 & & \\
\hline
\end{tabular}




\begin{tabular}{|c|c|c|c|c|c|}
\hline Jaar & Kwartaal & BTS & DFS & IBTS & MVII \\
\hline \multirow[t]{2}{*}{1987} & 3 & & 5 & & \\
\hline & 4 & & 13 & & \\
\hline 1988 & 4 & & 11 & 1 & \\
\hline 1989 & 4 & & 19 & & \\
\hline \multirow[t]{2}{*}{1990} & 3 & 1 & & & \\
\hline & 4 & & 19 & 1 & \\
\hline \multirow[t]{3}{*}{1991} & 1 & & & 2 & \\
\hline & 3 & 1 & & & \\
\hline & 4 & & 11 & & \\
\hline \multirow[t]{2}{*}{1992} & 3 & 1 & 1 & & \\
\hline & 4 & & 15 & 1 & \\
\hline \multirow[t]{2}{*}{1993} & 3 & 2 & & & \\
\hline & 4 & & 17 & 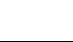 & \\
\hline \multirow[t]{3}{*}{1994} & 1 & & & 1 & \\
\hline & 3 & 1 & 1 & & \\
\hline & 4 & & 12 & & \\
\hline \multirow[t]{2}{*}{1995} & 3 & 1 & 1 & & \\
\hline & 4 & & 11 & & \\
\hline \multirow[t]{2}{*}{1996} & 3 & 1 & & & \\
\hline & 4 & & 13 & & \\
\hline 1997 & 4 & & 10 & & \\
\hline 1998 & 4 & & 8 & & \\
\hline 1999 & 4 & & 12 & & \\
\hline \multirow[t]{2}{*}{2000} & 3 & 1 & & & \\
\hline & 4 & & 11 & & \\
\hline 2001 & 3 & 2 & & & \\
\hline \multirow[t]{2}{*}{2002} & 3 & 1 & & & \\
\hline & 4 & & 14 & & \\
\hline \multirow[t]{2}{*}{2003} & 3 & 1 & 10 & & \\
\hline & 4 & & 3 & & \\
\hline \multirow[t]{2}{*}{2004} & 3 & 1 & & & \\
\hline & 4 & & 12 & & 10 \\
\hline \multirow[t]{4}{*}{2005} & 1 & & & 1 & 14 \\
\hline & 2 & & & & 163 \\
\hline & 3 & 1 & & & 107 \\
\hline & 4 & & 12 & & \\
\hline \multirow[t]{3}{*}{2006} & 2 & & & & 14 \\
\hline & 3 & 2 & & & \\
\hline & 4 & & 10 & & \\
\hline \multirow[t]{3}{*}{2007} & 2 & & & & 46 \\
\hline & 3 & 1 & & & 40 \\
\hline & 4 & & 13 & & \\
\hline \multirow[t]{2}{*}{2008} & 3 & 1 & & & \\
\hline & 4 & & 11 & & \\
\hline \multirow[t]{3}{*}{2009} & 2 & & & & 52 \\
\hline & 3 & 1 & & & 53 \\
\hline & 4 & & 12 & & \\
\hline \multirow[t]{2}{*}{2010} & 2 & & & & 53 \\
\hline & 3 & 2 & & & 49 \\
\hline
\end{tabular}




\begin{tabular}{|c|c|c|c|c|c|}
\hline Jaar & Kwartaal & BTS & DFS & IBTS & MVI \\
\hline & 4 & & 12 & & \\
\hline \multirow[t]{3}{*}{2011} & 2 & & & & 53 \\
\hline & 3 & 1 & & & \\
\hline & 4 & & 10 & & \\
\hline \multirow[t]{4}{*}{2012} & 1 & & & 1 & \\
\hline & 2 & & & & 42 \\
\hline & 3 & 1 & & & 40 \\
\hline & 4 & & 12 & & \\
\hline \multirow[t]{3}{*}{2013} & 2 & . & & & 44 \\
\hline & 3 & 1 & & & 42 \\
\hline & 4 & & 12 & & \\
\hline \multirow[t]{2}{*}{2014} & 1 & & & 1 & \\
\hline & 3 & 1 & 12 & & \\
\hline \multirow[t]{2}{*}{2015} & 3 & 1 & & & \\
\hline & 4 & & 12 & & 10 \\
\hline \multirow[t]{2}{*}{2016} & 3 & 1 & & & 8 \\
\hline & 4 & & 4 & & 10 \\
\hline 2017 & 1 & & & 1 & \\
\hline Totaal & & 28 & 733 & 10 & 850 \\
\hline
\end{tabular}




\section{Bijlage 4 Kaart garnalendichtheid Voordelta en Oosterschelde}

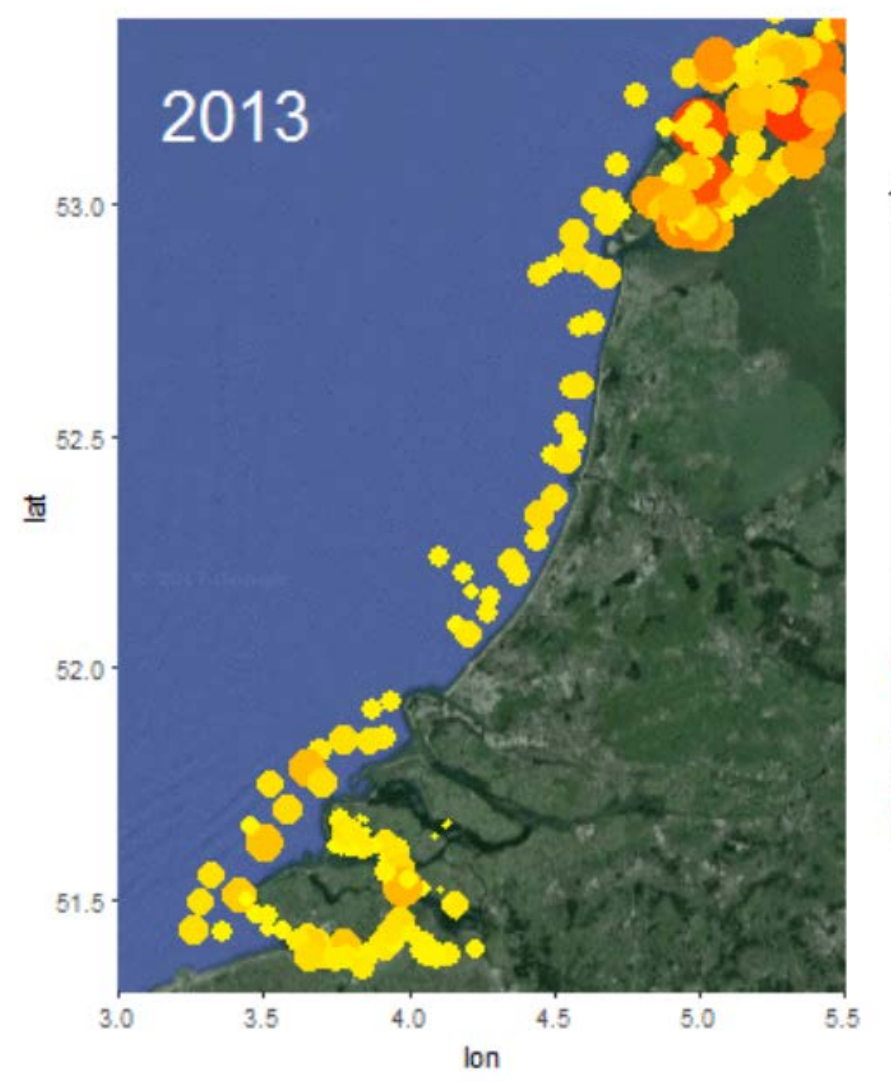

$\sqrt{\text { dichtheid garnaal }(\mathrm{n} / \mathrm{ha})}$

0

50

100

200

300

400

500

600

700

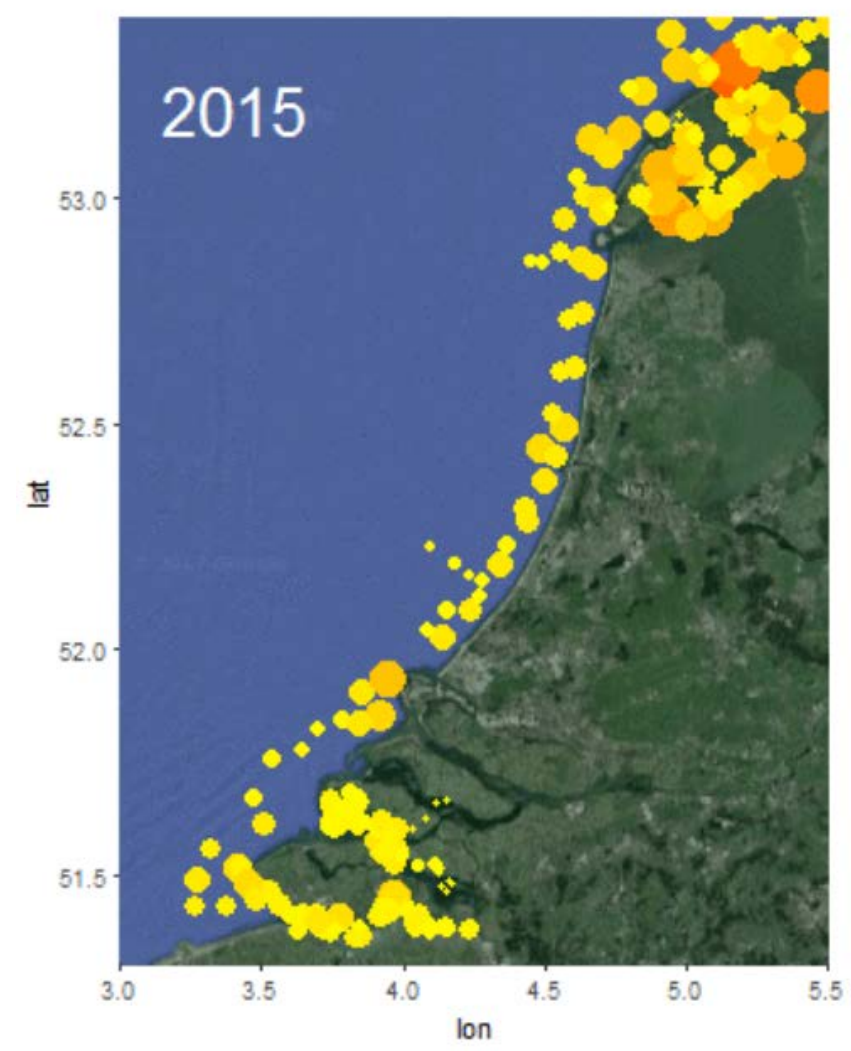

$\sqrt{\text { dichtheid garnaal (n/ha) }}$

0

50

100

200

300

400

500

600

700

Bron: WMR database 


\section{Bijlage 5 Kaart diepte Voordelta}

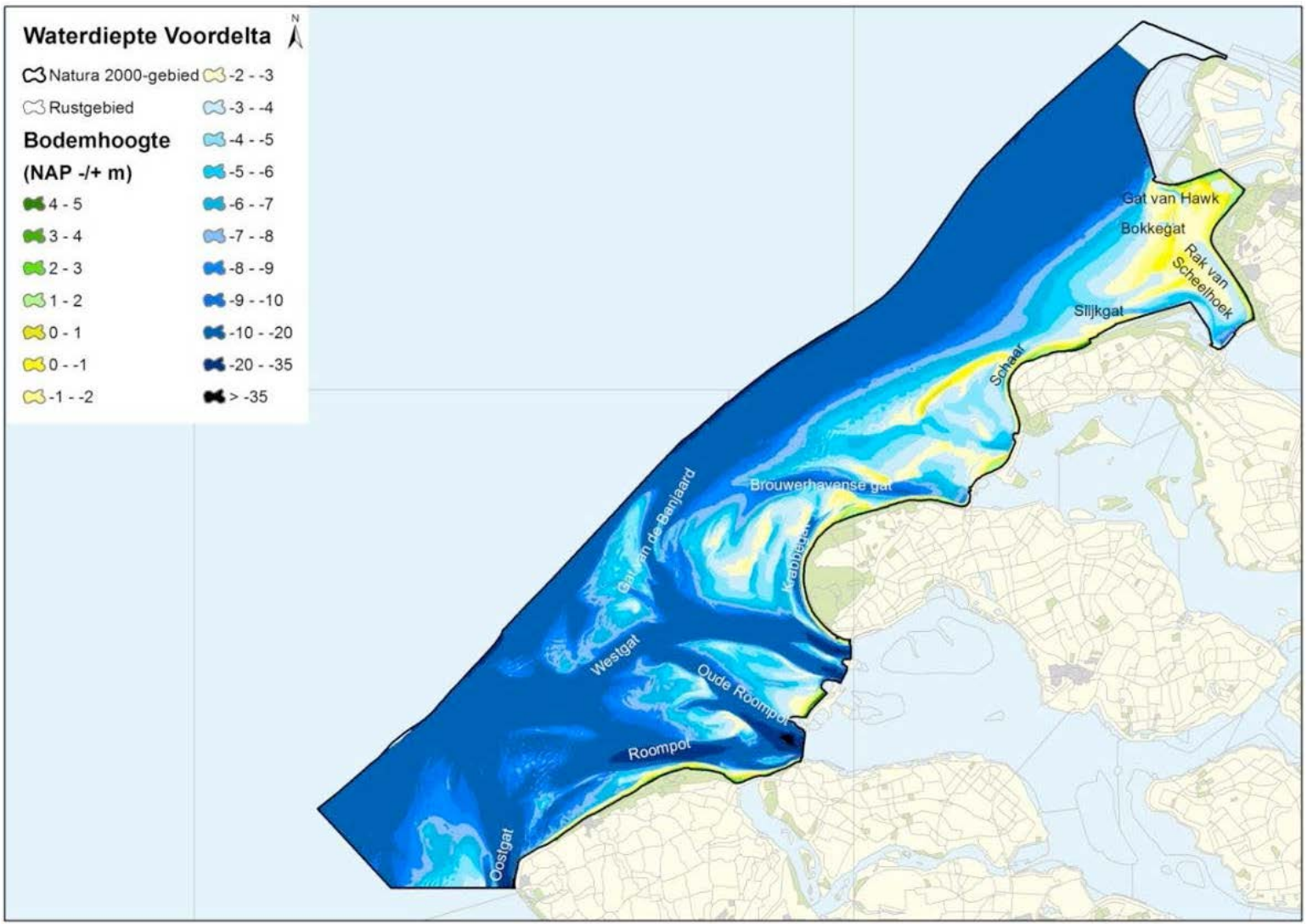

Bron: Ministerie van Infrastructuur en Milieu | Rijkswaterstaat (2016) 


\section{Bijlage 6 Kaart diepte Oosterschelde}

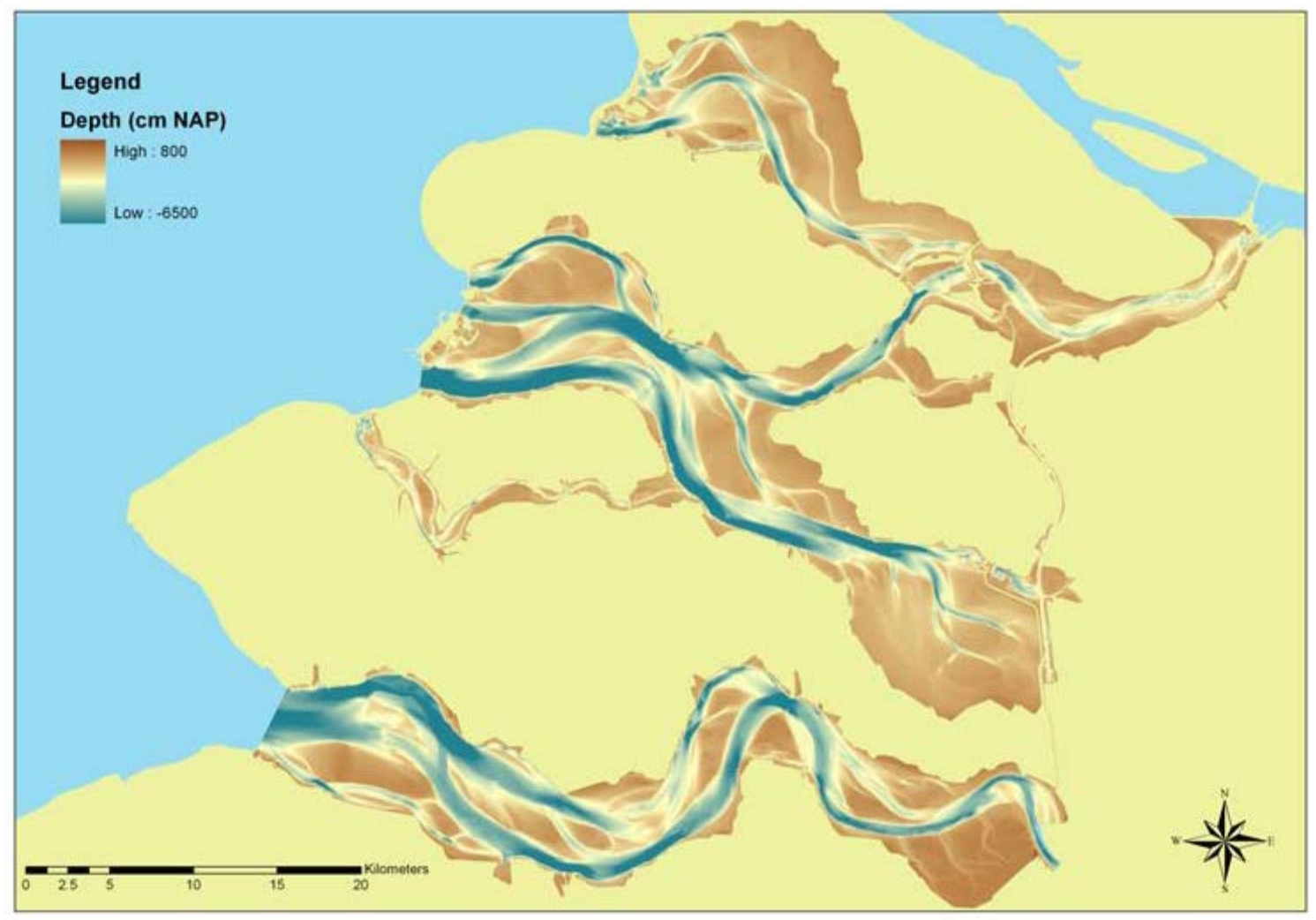

Bron: Schellekens et al. (2012) 


\section{Bijlage 7 Kaart sediment Voordelta}

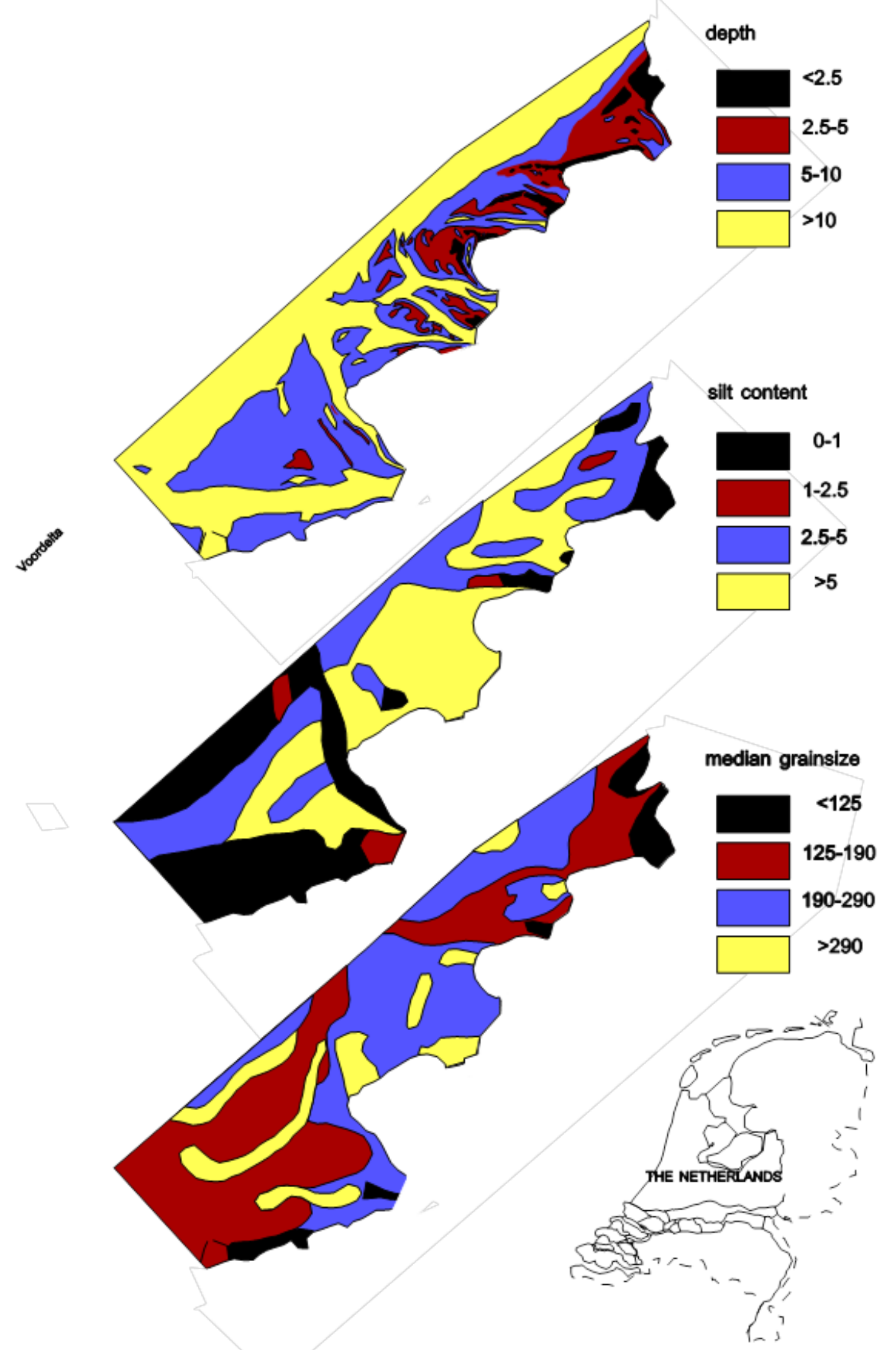

Sedimenttypering van de Voordelta. Oude kaart (eindjaren tachtig). Via J ohan Craeymeersch (WMR). 


\section{Bijlage 8 Kaart sediment en droogvalduur Oosterschelde}
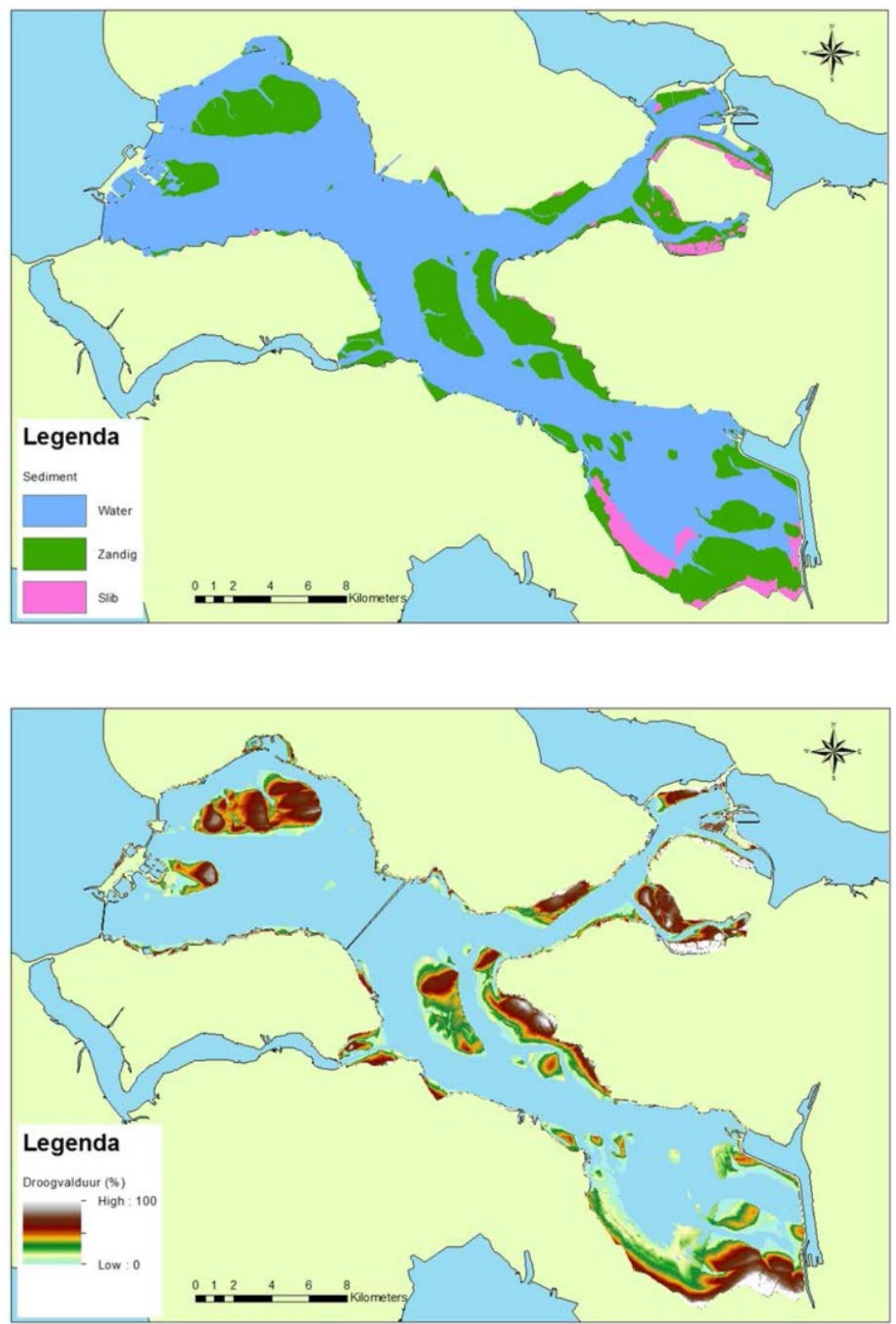

Bron: Henkens et al. (2012) 


\section{Bijlage 9 Kaart bodemschuifspanning Voordelta}
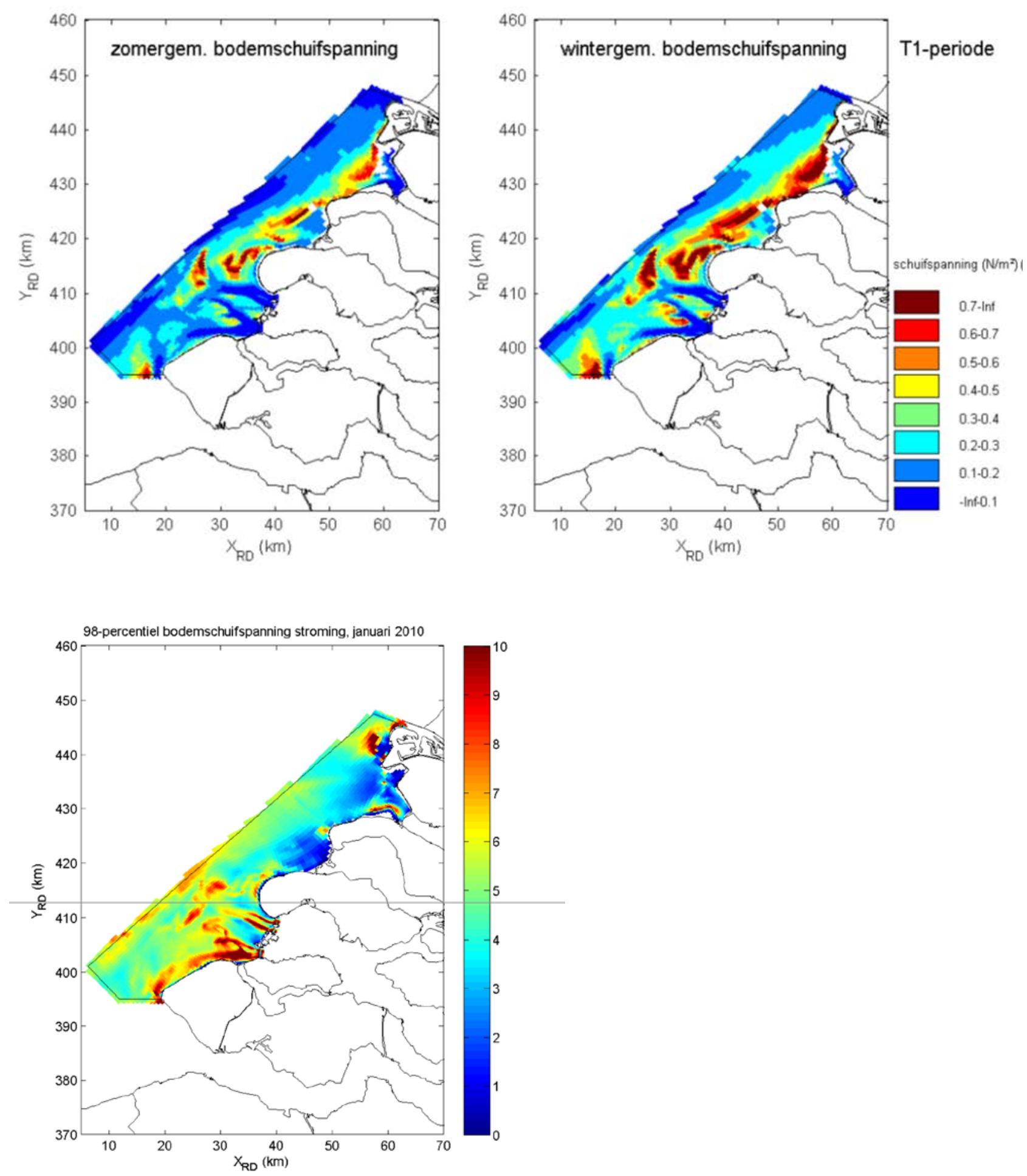

Bron: PMR monitoring natuurcompensatie Voordelta - Eindrapport 1e fase 2009-2013 Deel B, 1200672-000 (Van Banning \& Adema, 2014) 


\section{Bijlage 10 Kaart stroomsnelheid Oosterschelde}

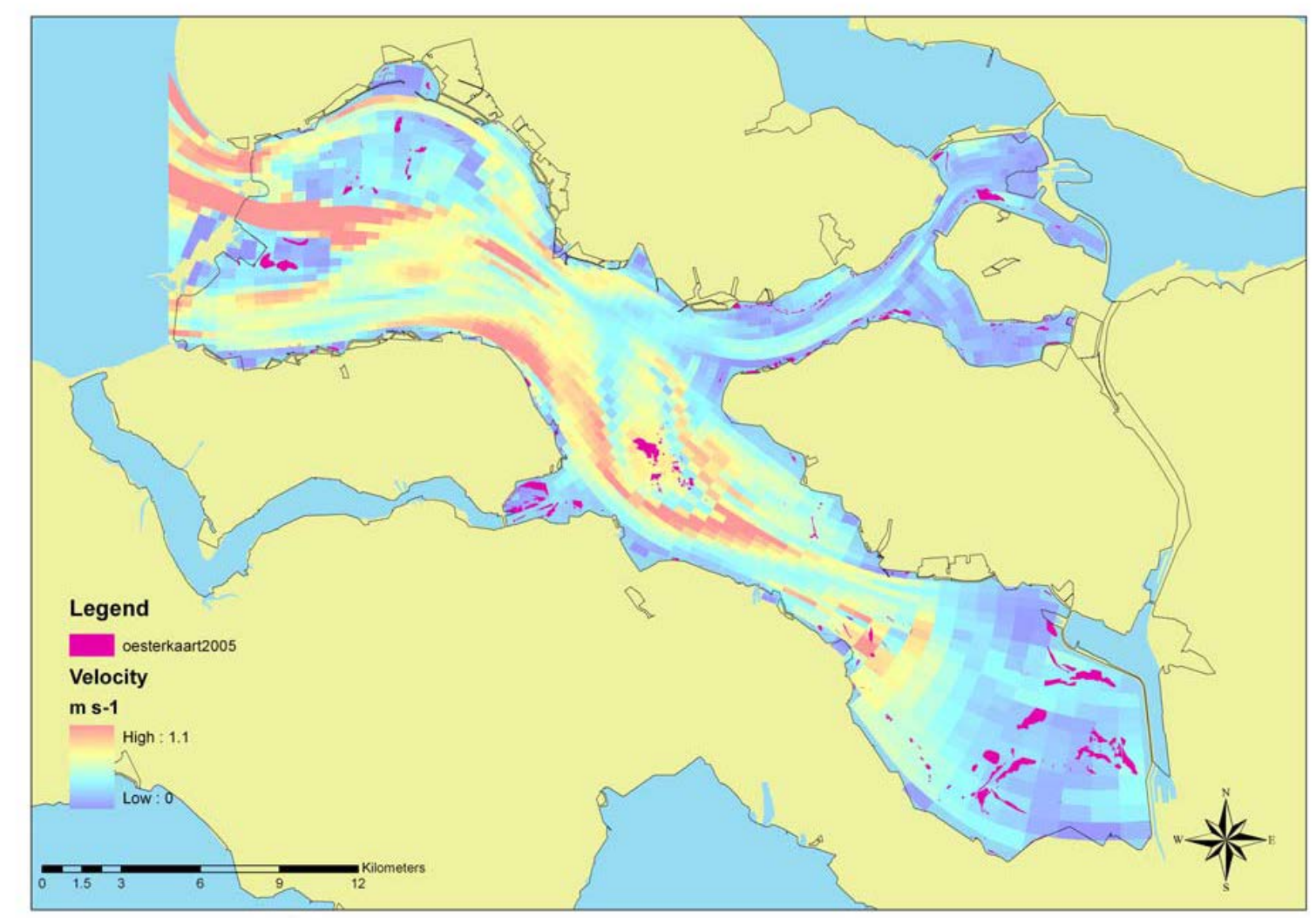

Stroomsnelheid (m s-1), berekend met het ScalOost Model voor de Oosterschelde in 1996 door Schellekens et al. (2012). 


\section{Bijlage 11 Kaart zoutgehalte Voordelta}
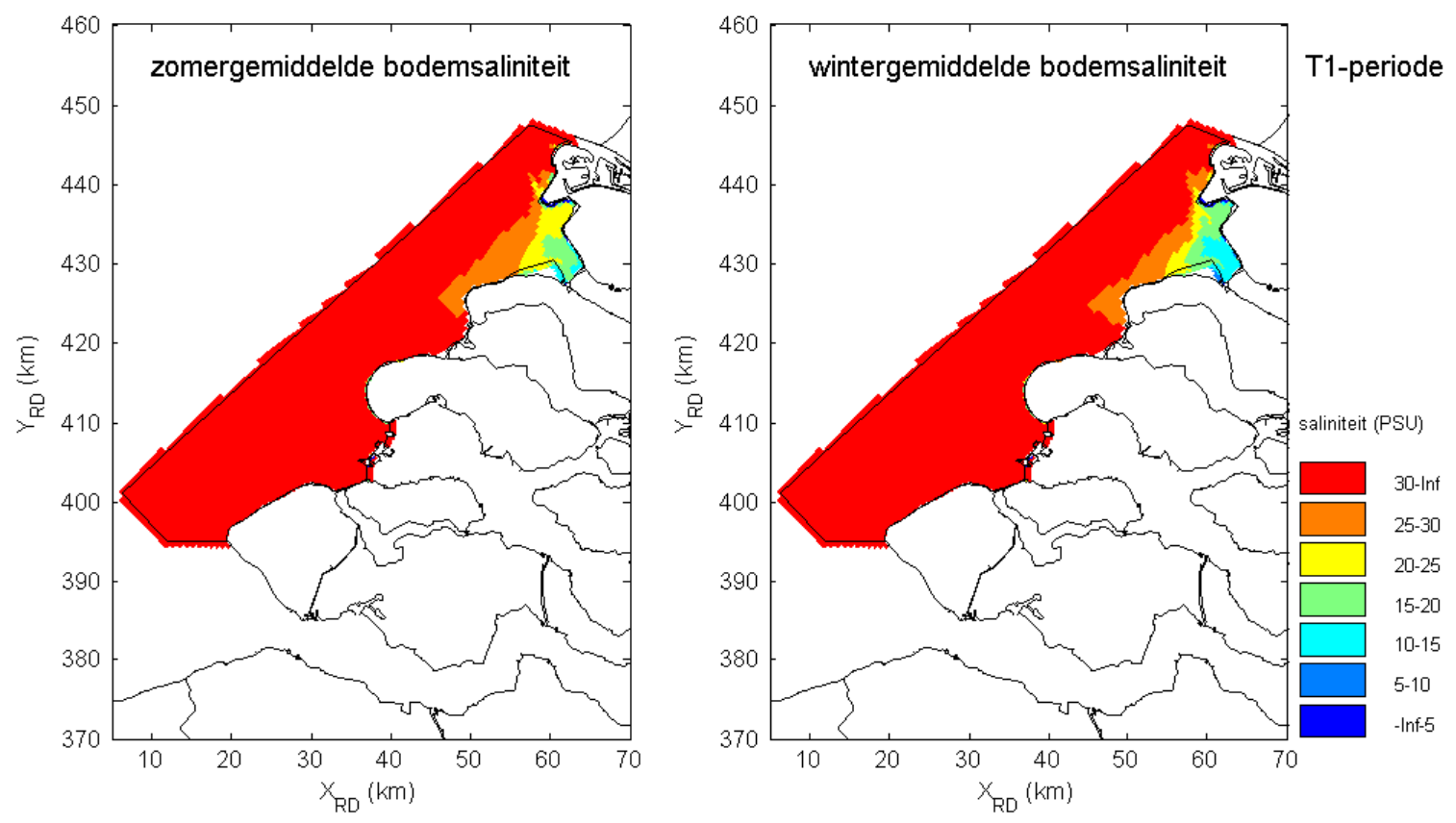

Bron: PMR monitoring natuurcompensatie Voordelta - Eindrapport 1e fase 2009-2013 Deel B, 1200672-000 (Van Banning \& Adema, 2014) 


\section{Bijlage 12 Grafiek zoutgehalte Oosterschelde}
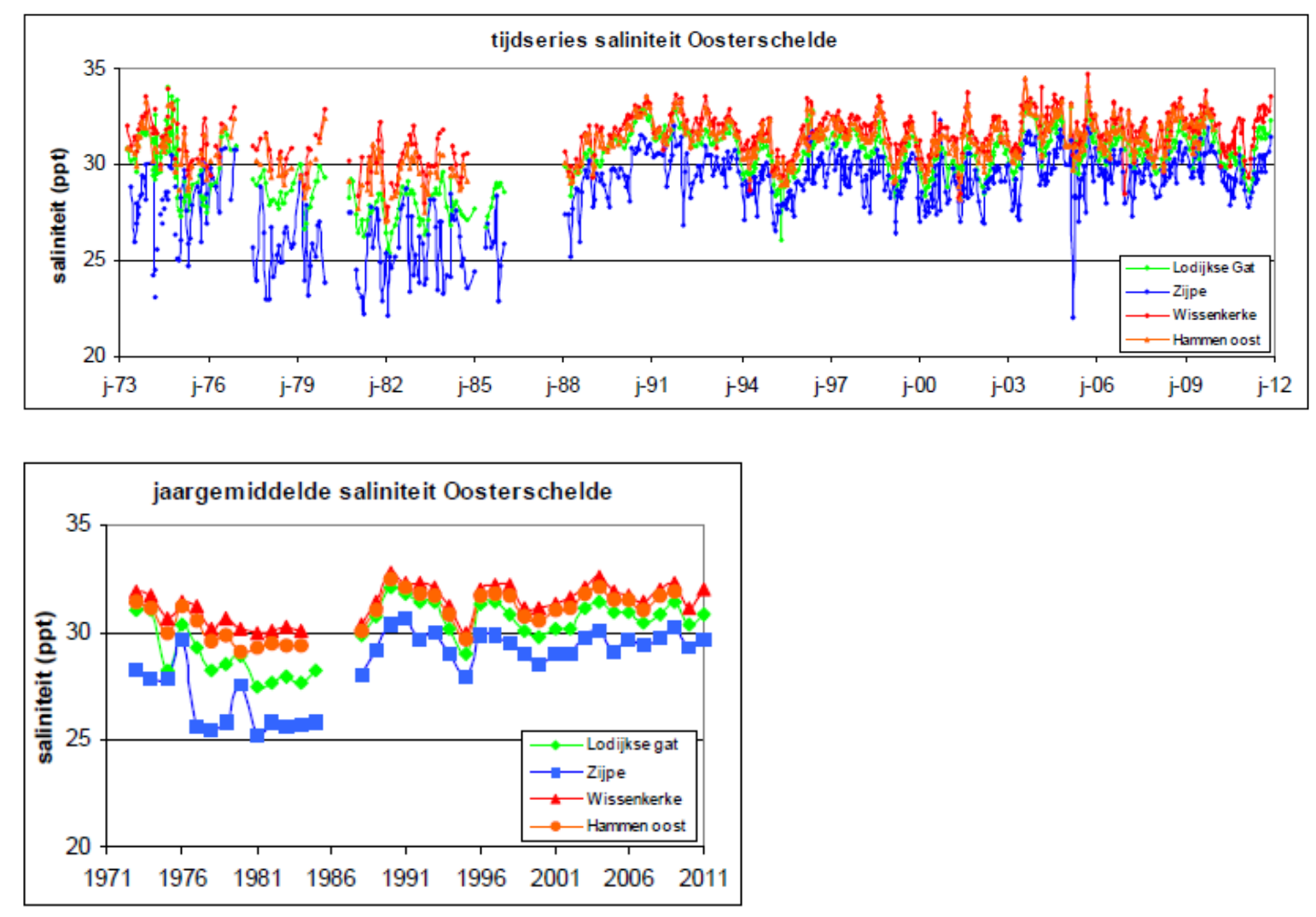

Saliniteit gemeten in water van de Oosterschelde. Bron: www.waterbase.nl (RWS) 


\section{Bijlage 13 Grafiek watertemperatuur Voordelta}

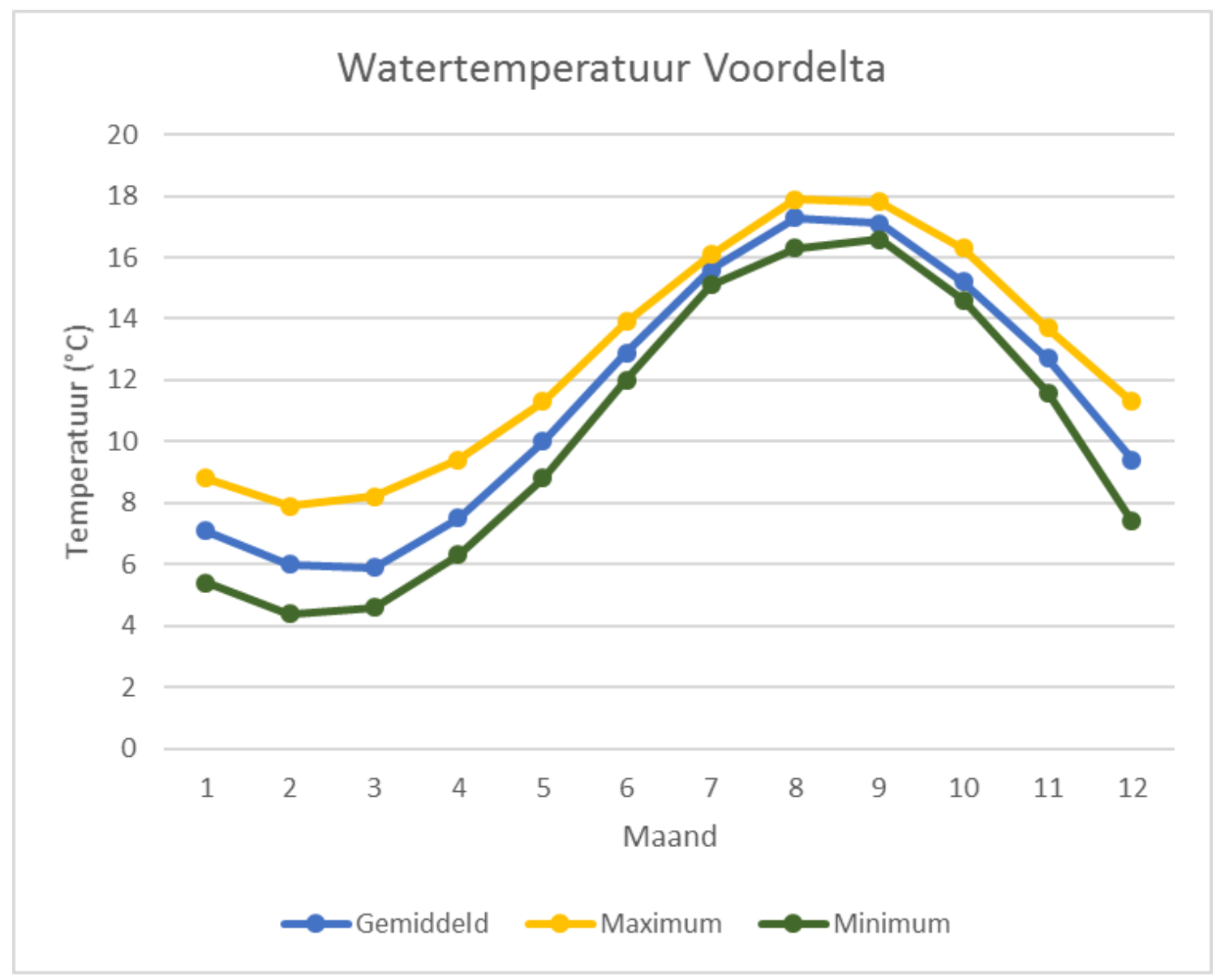

Watertemperatuur in de Voordelta. Maandgemiddelde voor periode $2004 \mathrm{t} / \mathrm{m} \mathrm{2012.} \mathrm{Meetpunt:} \mathrm{station}$ K13A. Bron: Waterbase 


\section{Bijlage 14 Grafiek watertemperatuur Oosterschelde}

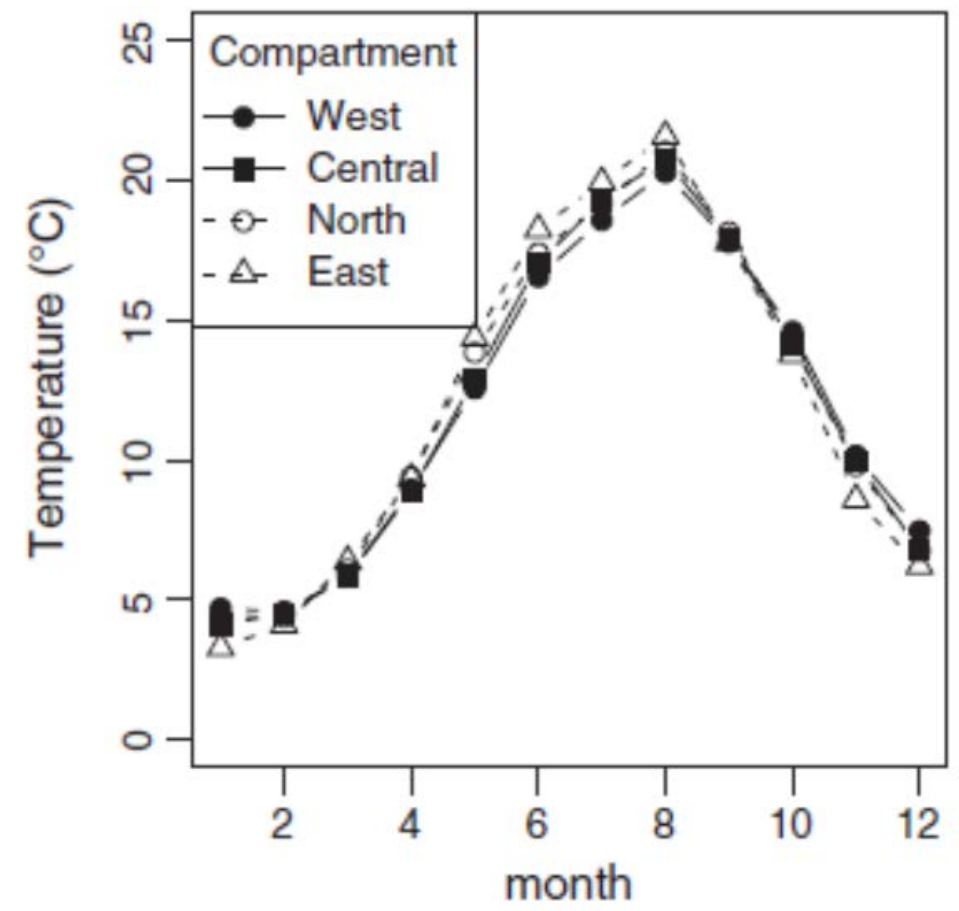

Bron: Wijsman \& Smaal (2011) 


\section{Bijlage 15 Kaart ecotopen Oosterschelde}

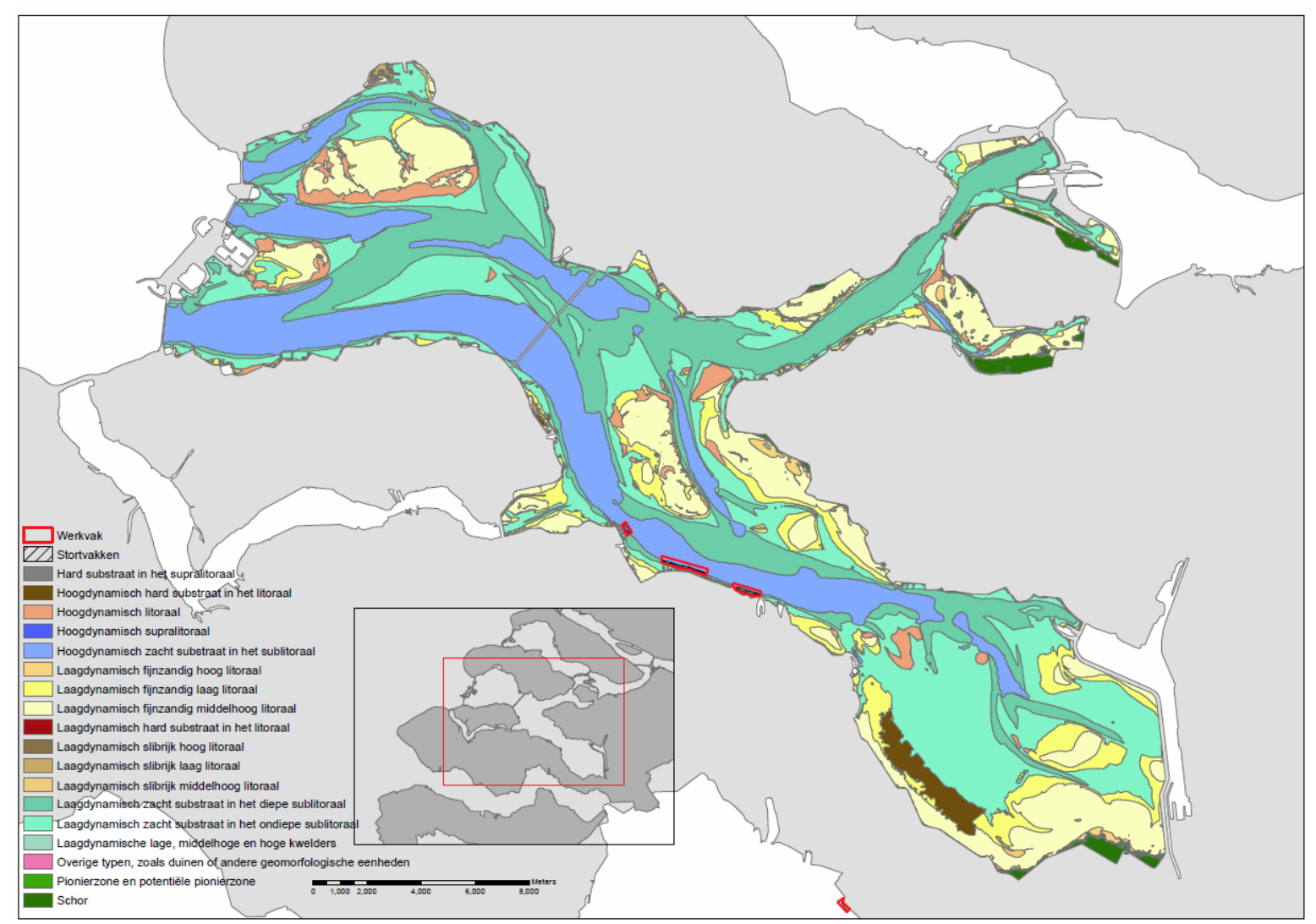

Ecotopenkaart van de Oosterschelde (2009/2010) uit Van den Heuvel-Greve et al. (2016) 
Wageningen Marine Research

T: +31 (0)317480900

E: marine-research@wur.nl

www.wur.nl/marine-research

Visitors address

- Ankerpark 271781 AG Den Helder

- Korringaweg 7, 4401 NT Yerseke

- Haringkade 1, 1976 CP IJ muiden
Wageningen Marine Research is the Netherlands research institute established to provide the scientific support that is essential for developing policies and innovation in respect of the marine environment, fishery activities, aquaculture and the maritime sector.

Wageningen University \& Research is specialised in the domain of healthy food and living environment.

The Wageningen Marine Research vision:

'To explore the potential of marine nature to improve the quality of life.'

The Wageningen Marine Research mission

- To conduct research with the aim of acquiring knowledge and offering advice on the sustainable management and use of marine and coastal areas.

- Wageningen Marine Research is an independent, leading scientific research institute.

Wageningen Marine Research is part of the international knowledge organisation Wageningen UR (University \& Research centre). Within Wageningen UR, nine specialised research institutes of Stichting Wageningen Research (a Foundation) have joined forces with Wageningen University to help answer the most important questions in the domain of healthy food and living environment. 